SANDIA REPORT

SAND98-1059

Unlimited Release

Printed June 1998
MSO Revtew \& ApprovarDesk for DOE/OSTI (12630)

SAND-- $98-1059$

\title{
Deveiopment of the Weapon Borne Sensor Parachute System
}

\author{
RECEIVED \\ JU木 18 M \\ 0871
}

Vance L. Behr

Prepared by

Sandia National Laboratories

Albuquerque, New Mexico 87185 and Livermore, California 94550

Sandia is a multiprogram laboratory operated by Sandia Corporation, a Lockheed Martin Company, for the United States Department of Energy under Contract DE-AC04-94AL85000.

Approved for public release; further dissemination unlimited. 
Issued by Sandia National Laboratories, operated for the United States Department of Energy by Sandia Corporation.

NOTICE: This report was prepared as an account of work sponsored by an agency of the United States Government. Neither the United States Government nor any agency thereof, nor any of their employees, nor any of their contractors, subcontractors, or their employees, makes any warranty, express or implied, or assumes any legal liability or responsibility for the accuracy, completeness, or usefulness of any information, apparatus, product, or process disclosed, or represents that its use would not infringe privately owned rights. Reference herein to any specific commercial product, process, or service by trade name, trademark, manufacturer, or otherwise, does not necessarily constitute or imply its endorsement, recommendation, or favoring by the United States Government, any agency thereof, or any of their contractors or subcontractors. The views and opinions expressed herein do not necessarily state or reflect those of the United States Government, any agency thereof, or any of their contractors.

Printed in the United States of America. This report has been reproduced directly from the best available copy.

Available to DOE and DOE contractors from

Office of Scientific and Technical Information

P.O. Box 62

Oak Ridge, TN 37831

Prices available from (615) 576-8401, FTS 626.8401

Available to the public from

National Technical Information Service

U.S. Department of Commerce

5285 Port Royal Rd

Springfield, VA 22161

NTIS price codes

Printed copy: A03

Microfiche copy: A01

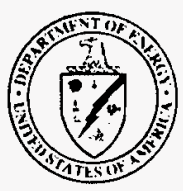


SÄND98-1059

Distribution

Unlimited Release

Printed May 1998

Category UC-700

\title{
DEVELOPMENT OF THE \\ WEAPON BORNE SENSOR \\ PARACHUTE SYSTEM
}

\author{
Vance L. Behr \\ Unsteady and Reactive Fluid Mechanics Department \\ Sandia National Laboratories \\ Albuquerque, NM 87185-0836
}

\begin{abstract}
A parachute system was designed and prototypes built to deploy a telemetry package behind an earth-penetrating weapon just before impact. The parachute was designed to slow the 10-lb telemetry package and wire connecting it to the penetrator to 50 fps before impact occurred. The parachute system was designed to utilize a 1.3-ft-dia cross pilot parachute and a 10.8-ft-dia main parachute. A computer code normally used to model the deployment of suspension lines from a packed parachute system was modified to model the deployment of wire from the weapon forebody. Results of the design calculations are presented. Two flight tests of the WBS were conducted, but initiation of parachute deployment did not occur in either of the tests due to difficulties with other components. Thus, the trajectory calculations could not be verified with data. Draft drawings of the major components of the parachute system are presented.
\end{abstract}




\section{ACKNOWLEDGEMENTS}

The author would like to thank Larry Whinery, Richard Brazfield, and Richard Zuni for their help in fabrication, packing, and drawing in support in this project. Thanks also to David Sundberg for the computer code modifications that were required and to Don Waye for the initial analyses for this project. This work was conducted for the Air Force Wright Laboratory Armament Directorate, WL/MNMF, Eglin AFB, Florida under MIPR number NY762197. Sandia National Laboratories is operated for the Department of Energy under Contract DE-AC04-94AL85000. 


\section{DISCLAIMER}

This report was prepared as an account of work sponsored by an agency of the United States Government. Neither the United States Government nor any agency thereof, nor any of their employees, makes any warranty, express or implied, or assumes any legal liability or responsibility for the accuracy, completeness, or usefulness of any information, apparatus, product, or process disclosed, or represents that its use would not infringe privately owned rights. Reference herein to any specific commercial product, process, or service by trade name, trademark, manufacturer, or otherwise does not necessarily constitute or imply its endorsement, recommendation, or favoring by the United States Government or any agency thereof. The views and opinions of authors expressed herein do not necessarily state or reflect those of the United States Government or any agency thereof. 


\section{CONTENTS}

NOMENCLATURE $\quad 4$

INTRODUCTION

WEAPON BORNE SYSTEM OVERVIEW 6

SYSTEM REQUIREMENTS $\quad 8$

SYSTEM DESIGN

Main Parachute $\quad 9$

Pilot Parachute $\quad 13$

Other System Components $\quad 13$

TRAJECTORY ANALYSIS/EVENT TIMING 16

Tail-Cone Ejection/Pilot Parachute Deployment $\quad 16$

Pilot Parachute Inflation/Main Parachute Deployment $\quad 18$

Main Parachute Inflation/TM package Deceleration/Wire Dispensing 19

Full Trajectory Summary and Parametric Variations 19

TEST RESULTS

CONCLUSIONS $\quad 24$

$\begin{array}{ll}\text { REFERENCES } & 25\end{array}$

APPENDICES $\quad 26$

Appendix A: Draft Drawings of Parachute System Components 27

10.8-Ft-Dia Cross, Main Parachute Drawings 28

Main Parachute Bag Drawings 40

1.3-ft-dia Pilot Parachute Drawings 47

Telemetry Package Sling Drawings 56

Appendix B: WBS Packing and Installation Checklist and Manual 59

WBS Parachute System Packing Checklist 59

WBS/Parachute Installation Manual

Appendix C: Nominal WBS Trajectory $\quad 72$ 


\section{NOMENCLATURE}

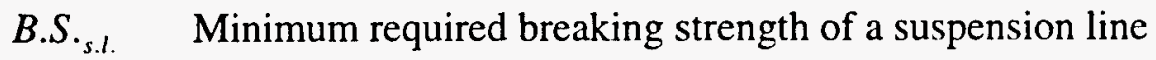

$C_{D} S \quad$ Nominal full open drag area of the parachute

$C_{X} \quad$ Parachute opening shock factor (or added mass factor)

$d_{\text {fill }} \quad$ Filling distance of a parachute canopy

D.F. Design Factor to ensure adequate safety margins in the design

$D_{p} \quad$ Flying diameter of the parachute canopy

$E_{\text {spring }} \quad$ Energy stored in the tail cone ejection springs

$F_{\text {drag }} \quad$ Drag force

$F_{\text {friction }} \quad$ Force required to break the wire free from the packed configuration (friction and mold release forces included)

$F_{\text {ineria }} \quad$ Force due to the inertial loads of the wire

$F_{\max } \quad$ Maximum expected load

$k \quad$ Spring constant of an individual tail cone ejection spring

$\dot{m} \quad$ Rate at which mass is being picked up by the parachute while spooling from the dispenser

$m_{\text {tail-cone }}$ Mass of the tail-cone

M.S. Margin of Safety

$n_{\text {fill }} \quad$ Filling constant for a parachute canopy

$n_{\text {s.l. }} \quad$ Number of suspension lines

$n_{\text {springs }} \quad$ Number of tail cone ejection springs

$q_{\text {deploy }} \quad$ Dynamic pressure

$t_{c} \quad$ Minimum required fabric strength (force/unit length)

$V \quad$ Velocity of the parachute

$V_{\text {tail-cone }} \quad$ Velocity of the tail-cone

$\Delta V \quad$ Velocity change imparted to the wire as it leaves the dispenser

$W_{T M} \quad$ Weight of the TM package

$W_{\text {wire }} \quad$ Weight of the deployed wire

$x \quad$ Amount the tail cone ejection springs are compressed

$X_{1} \quad$ Force reduction factor

$\rho_{\text {air }} \quad$ Density of the air

$\rho_{\text {wire }} \quad$ Linear density of the wire 


\section{INTRODUCTION}

This report documents the development of a parachute system for the Weapon Borne Sensor program. This effort was undertaken on behalf of the Air Force as an Advanced Concept Technology Demonstration within the Counter Proliferation Initiative. The funding agency was the Air Force Wright Laboratory Armament Directorate located at Eglin AFB, Florida.

The concept of the WBS program is to develop an enhanced conventional penetrator that uses a parachute-deployed transmitter to convey information back to the delivery aircraft about the nature of the impact/penetration. By deploying a parachute just before impact that decelerates a telemetry package connected to the penetrator by a spooling wire, accelerometer data can be transmitted back for evaluation. One of the challenges of such a system is designing a spooling wire system that can function at wire-dispensing speeds of $\sim 900 \mathrm{fps}$ and a wire that will remain intact in the hole left behind the penetrator to meaningful penetration depths. An important factor that influences wire survivability is the velocity of the wire relative to the surrounding walls of the penetration hole. The wire velocity is determined by the sizing of the parachute system. 


\section{WEAPON BORNE SYSTEM OVERVIEW}

The Weapon Borne System (WBS) is targeted at providing real time data on target structure. This data includes number of concrete, air void, and soil layers penetrated and location and/or time of detonation. Being an Advanced Concept Technology Demonstrator (ACTD) program, the system is envisioned to integrate mature technologies in a minimum of developmental tests and with a number of units remaining as a residual capability. Because of this requirement the WBS was designed to interface with the existing BLU-109, 2000-lbm penetrator and the GBU-24 tail kit with no or minimal modifications.

The system is comprised of an accelerometer sensor subsystem, a spooling wire subsystem, a telemetry and power (TM) subsystem, a parachute subsystem, a proximity sensor/initiation subsystem and all the integrating hardware. The entire WBS is shown schematically in cross section in Figure 1. The accelerometer subsystem is mounted intimately on the aft bulkhead of the BLU-109. The wire dispenser is mounted just aft of the accelerometer subsystem and contains over $700 \mathrm{ft}$ of multi-conductor cable that allows the accelerometer subsystem to communicate with and receive power from the TM subsystem. A tube located within the void space in the center of the GBU-24 tail kit houses the TM and parachute subsystems. The proximity sensor is located at the far aft end of the fin kit. A dome cover on the tail is equipped to be released and propelled into the trailing air stream by springs and explosive bolts and is hereafter referred to in this report as the "tail cone."

The system integrator for the WBS was the Albuquerque office of Applied Research Associates (ARA). ARA was also responsible for the wire dispenser and tail cone ejection system. The Wright Laboratory/Armament Directorate at Eglin AFB, FL, designed the accelerometer and TM systems. The Army Research Development and Engineering Command (ARDEC) designed the proximity sensor. Personnel from the Unsteady and Reactive Fluid Mechanics Department 9116 of Sandia National Laboratories designed the parachute system. 


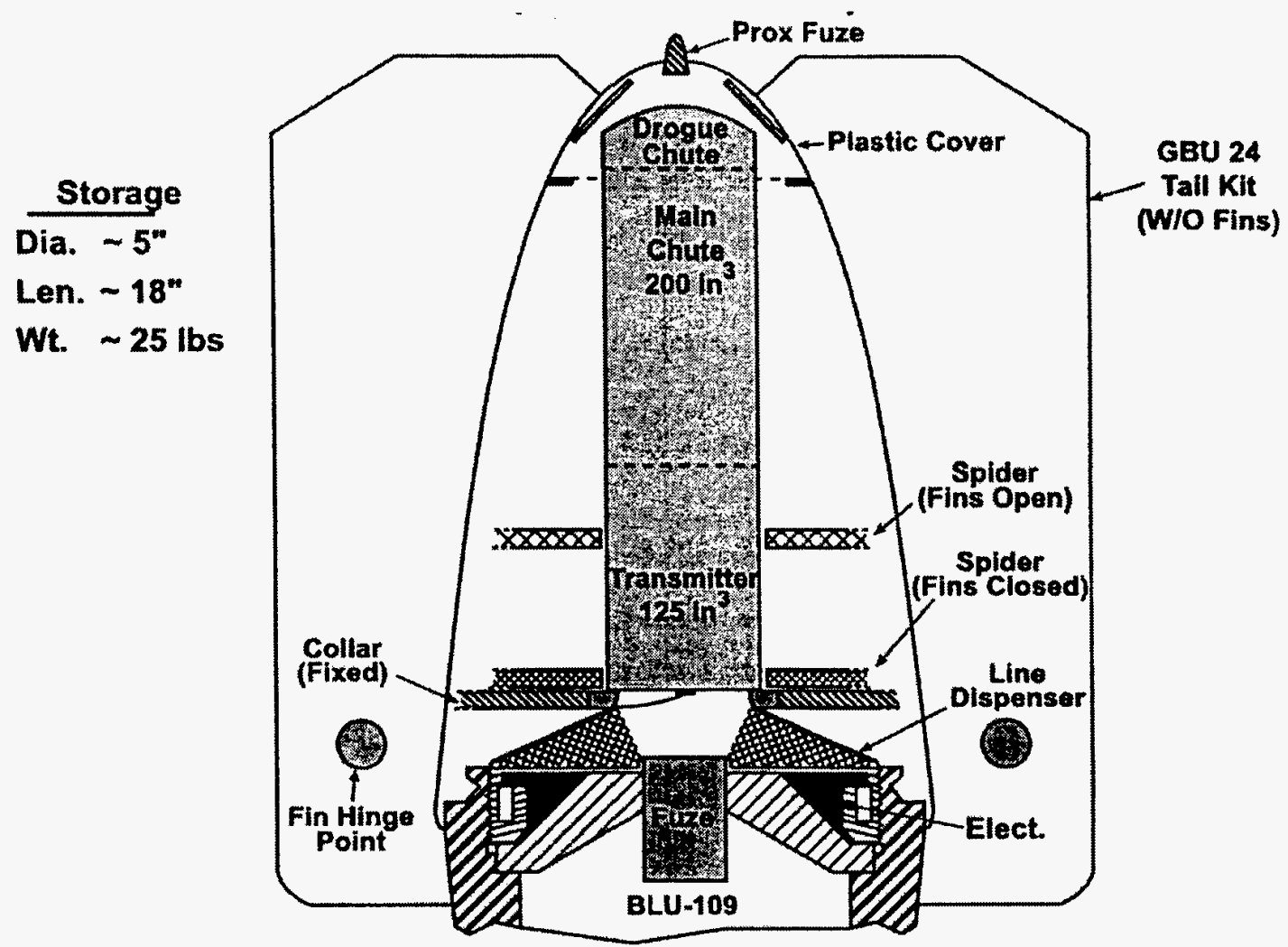

Figure 1. Schematic side view of WBS system components in GBU-24 tail kit. 


\section{SYSTEM REQUIREMENTS}

The requirements for the parachute system were initially specified, but considered to be negotiable, within limits, recognizing that the initial specifications may have conflicted with one another. The initial specifications were as follows:

Deploy a telemetry (TM) package from the aft end of a GBU-24 during flight.

Be fully deployed in $0.15 \mathrm{sec}$.

Reduce total velocity of TM package from $800-1000$ fps to $<100$ fps.

Deceleration should occur within $400 \mathrm{ft}$.

Weight of TM package and signal wire (when fully deployed) 25 lbs.

Parachute pack volume 200 in $^{3}$ (4.8 in. dia. X 11 in. long).

As the program progressed, some of these specifications changed and more were added:

Parachute pack volume was reduced by the amount required to accommodate a blade antenna on top of the TM package.

Maximum deployed wire at time of impact increased to $600 \mathrm{ft}$.

Maximum TM acceleration of $365 \mathrm{~g}$ 's was accepted.

Desired to have wire velocity $w / r / t$ ground $<50$ fps.

Provisions needed to be made for routing a ribbon cable through the parachute compartment.

The original requirements of being deployed in $0.15 \mathrm{sec}$ of deceleration in $400 \mathrm{ft}$ was deleted in favor of the requirement on maximum amount of deployed wire.

The combined weight of the TM package and wire was reduced to $13 \mathrm{lbs}$.

Based upon the revised set of requirements, a parachute system was designed using the tail cone to deploy a pilot parachute that deployed a main parachute for the deceleration of the TM package and deployment of the wire. 


\section{SYSTEM DESIGN}

Sizing of the parachutes was done in stages. First the main parachute was sized. This then allowed an estimate to be made of the main parachute weight, a parameter required for the sizing of a pilot parachute.

\section{Main Parachute}

An initial estimate of the main parachute size was calculated from basic drag equations for parachutes using steady state values for the descent velocity and wire strip out force. As the main parachute design firmed up, a computer code was used to obtain more accurate timing information and to estimate the peak loads in a dynamic environment.

The force required of the main parachute can be broken into individual components as follows:

$$
F_{\text {drag }}=F_{\text {inertia }}+F_{\text {friction }}+W_{\text {wire }}+W_{T M}
$$

where:

$$
\begin{aligned}
& F_{\text {drag }} \text { is the required steady state drag force, } \\
& F_{\text {ineria }} \text { is the force required due to the inertial loads of the wire, } \\
& F_{\text {friction }} \text { is the force required break the wire free from the packed } \\
& \text { configuration (friction and mold release included), } \\
& W_{\text {wire }} \text { is the weight of the deployed wire, and } \\
& W_{T M} \text { is the weight of the TM package. }
\end{aligned}
$$

The main parachute was originally sized using a descent velocity of $40 \mathrm{fps}$ and estimates of the TM package weight $(15 \mathrm{lbs})$ and the inertial and friction forces of dispensing the wire $\left(10 \mathrm{lbs}\right.$.). Based upon this, a required drag area of approximately $15 \mathrm{ft}^{2}$ was calculated. However, as the problem was analyzed more carefully, it was learned that the inertial loads of deploying the wire drive the size of the parachute more than the weight of the TM package.

Using the conservation of momentum, the force required by the parachute to deploy the wire can be written as follows:

$$
F_{\text {ineria }}=\dot{m} \Delta V
$$

where:

$\dot{m} \quad$ is the rate at which mass is being picked up by the parachute while spooling wire from the dispenser, and 
$\Delta V \quad$ is the velocity change imparted to the wire as it leaves the dispenser.

The rate of mass addition of the wire can be related to the mass per unit length of the wire, $\rho_{\text {wire }}$, and the velocity change imparted to the wire such that equation (2) becomes:

$$
F_{\text {ineria }}=\rho_{\text {nire }}(\Delta V)^{2}
$$

The drag area required to produce a given amount of force, at a specified steady parachute velocity can be calculated as:

$$
C_{D} S=\frac{F_{d r a g}}{\frac{1}{2} \rho_{a i r} V^{2}}
$$

where:

$$
\begin{array}{ll}
C_{D} S & \text { is the required drag area, } \\
\rho_{\text {air }} & \text { is the density of the air, and } \\
V & \text { is the velocity of the parachute. }
\end{array}
$$

Initial estimates for the wire density were $6 \mathrm{lbm} / 1000 \mathrm{ft}$. Using this density and a differential velocity of $960 \mathrm{fps}$ (penetrator velocity of $1000 \mathrm{fps}$ and a steady state wire velocity of $40 \mathrm{fps}$ ), the drag force required by the parachute just to overcome inertial effects is approximately $100 \mathrm{lbf}$. Adding to this a $17.5 \mathrm{lbf}$ estimate of the weight of the TM package and wire (fully deployed) and an estimate of $10 \mathrm{lbf}$ for friction, yielded a drag area requirement of $107 \mathrm{ft}^{2}$. Later more refined estimates of TM weight (10 lbf) and wire density $(4.1 \mathrm{lbm} / 1000 \mathrm{ft})$ led to a revised estimate of required drag area of $63.9 \mathrm{ft}^{2}$.

Past experience with some prior programs that utilized a wire dispenser indicated that the inertial loads would only be half that as dictated by equation (3). Using that in Equations (1) and (4) yields a required drag area for the parachute of $32 \mathrm{ft}^{2}$. Unfortunately, this results in a very large discrepancy in drag area. Sizing the parachute too small would result in an excessive wire velocity relative to the ground. Too large of a parachute would result in deploying all of the wire before the penetrator impacted the ground. As a compromise the two estimates were averaged, resulting in a required drag area of $48 \mathrm{ft}^{2}$.

Various types of parachutes could be used to achieve this drag area. Given the difficulties in and the short times available for the receiving aircraft to lock onto the transmitted signal, it seemed prudent to utilize a parachute type that demonstrates very stable behavior. It also seemed prudent to select a design that was simple and hence inexpensive to fabricate. While guide surface parachutes are very stable, they are costly to build. Flat circular or conical solids are relatively easy to build but typically demonstrate oscillatory behavior during descent. A cross (or cruciform) parachute is 
both simple to build and, if designed properly, very stable. Thus, a cross parachute was chosen for the main parachute design.

A cross parachute typically has a drag coefficient in the range of $0.6-0.85 .^{1}$ Using a drag coefficient of 0.8 , the desired drag area of $48 \mathrm{ft}^{2}$ dictates a 10.8-ft-dia cross parachute. Knowing the size of the parachute, the dynamic pressure at the time of deployment, and the payload weight, an initial estimate of the maximum load can be made using the following equation.

$$
F_{\max }=q_{\text {deploy }}\left(C_{D} s\right) C_{X} X_{1}
$$

where:

$$
\begin{aligned}
& F_{\max } \text { is the maximum expected load, } \\
& q_{\text {deploy }} \text { is the dynamic pressure at the time of deployment initiation, } \\
& C_{D} S \text { is the nominal full open drag area of the parachute, } \\
& C_{X} \text { is the opening shock factor, and } \\
& X_{1} \quad \text { is a force reduction factor. }
\end{aligned}
$$

The opening shock factor (or added mass factor) is used to account for dynamic loads that result from the initial inrush of air and its momentum when a canopy initially opens. It is an empirically derived coefficient and is usually considered to be constant for a given parachute type. For a cross parachute it is usually in the range of 1.1-1.2. ${ }^{1}$

The force reduction factor is used to account for the fact that during the canopy inflation process, the payload is itself slowing down due to the drag produced by the canopy. Thus, by the time the canopy has reached full open status, the velocity, and hence the dynamic pressure, has already diminished from what existed at the beginning of the inflation process. This factor is determined empirically and is based upon the ratio of included mass in the canopy and the payload mass. In the case of the WBS parachute and payload, the force reduction factor is quite significant, something less than 0.1 .

For lightly loaded, unreefed canopies, such as the WBS parachute, convention is to disregard the opening shock factor ${ }^{2}$. In order to be conservative, a force reduction factor of 0.1 was assumed. The nominal delivery velocity of $900 \mathrm{fps}$ at sea level conditions yields a dynamic pressure of 963 psf. Using these values a maximum deployment force for the main parachute is calculated to be $4622 \mathrm{lbf}$. 
With the maximum force known, simple membrane theory can be used to estimate the required fabric strength for the canopy. By assuming the canopy inflates in a spherical shape and that the maximum force occurs at the time of maximum flying diameter (a very conservative assumption in this case of very low mass ratios), the following equation can be used:

$$
t_{c}=\frac{F_{\max }}{\pi D_{p}}(D . F .)
$$

where:

$t_{c} \quad$ is the minimum required fabric strength (force/unit width),

$D_{p} \quad$ is the flying diameter of the parachute canopy, and

D.F. is the appropriate design factor to ensure adequate safety margins in the design.

A 10.8 -ft-dia cross parachute will fly at a maximum diameter of approximately $5.8 \mathrm{ft}$. A typical design factor for single use parachutes in ordnance applications is 2.2. Using these values and the previously calculated maximum force, yields a minimum required fabric strength of $47 \mathrm{lbf} / \mathrm{in}$. This allows the use of 2.25oz/yd ${ }^{2} \mathrm{MIL}-\mathrm{C}-7350$, Type I, nylon canopy cloth that has a rated strength of $90 \mathrm{lbf} / \mathrm{in}$.

The suspension lines can be sized based upon the maximum force, the number of lines and a design factor as well. This relationship can be written as:

$$
B_{. S . l .}=\frac{F_{\max }}{n_{s . l .}}(D . F .)
$$

where:

$$
\begin{aligned}
& B . S_{\text {s.l. }} \text { is the minimum required breaking strength of a suspension } \\
& \text { line, and } \\
& n_{s . l .} \quad \text { is the number of suspension lines. }
\end{aligned}
$$

Choosing five lines per panel on the cross parachute results in a total of 20 suspension lines and ensures an intersection of lines at the very apex of the canopy. This intersection allows for a centered attachment point for a vent break cord for the main parachute. Using the same design factor of 2.2 , results in a minimum required suspension line strength of $508 \mathrm{lbf}$. This allows the use of MIL-C-7515, Type II, nylon cord (a very common material) with a 550 lbf breaking strength (lb-brkg-str) for suspension lines. 
Given the material selection, the actual margins of safety (M.S.) can be calculated as:

$$
M . S .=\frac{(\text { Actual Strength })-(\text { Minimum Required Strength })}{(\text { Minimum Required Strength })}
$$

This results in margins of safety of 0.9 and 0.1 for the canopy cloth and suspension lines, respectively.

The full details of the construction of the main canopy can be found on draft drawings included as Appendix A. The initial estimate of the weight of the main parachute was 2.2 $\mathrm{lbm}$ for the canopy and $1.1 \mathrm{lbm}$ for the suspension lines for a total weight of $3.3 \mathrm{lbm}$.

\section{Pilot Parachute}

In order to keep bag strip velocities for the main parachute manageable ( $<400 \mathrm{fps}$ ), the drag area for the pilot parachute was chosen to be $0.9 \mathrm{ft}^{2}$. Once again for stability and ease of manufacture, a cross parachute design was chosen for the pilot parachute. A 19-inch-diameter cross parachute is required to generate the desired drag area.

Using the same process as outlined previously for the main parachute, the maximum force for the pilot parachute was calculated to be $312 \mathrm{lbf}$. For this load and an inflated diameter of $0.84 \mathrm{ft}$, the minimum required fabric strength is $22 \mathrm{lbf} / \mathrm{in}$. Since pilot parachutes often encounter very harsh deployment conditions, they are typically over designed to accommodate unforeseen excess loading. This is possible because their small size results in adding very little to the overall system weight. Thus, the same material used for the main canopy was chosen for the pilot parachute canopy as well.

Using the maximum load, only two lines per panel on the pilot parachute (eight lines total) and the same design factor of 2.2 , the minimum required strength for the suspension lines is $85.8 \mathrm{lbf}$. While very small braided nylon cord is available with just slightly higher breaking strengths, it is very difficult to work with. Thus, the more manufacture friendly MIL-C-7515, Type XI, braided nylon cord with a breaking strength of $300 \mathrm{lbf}$ was chosen. This also provided for additional safety margins for the pilot parachute.

In the case of the pilot parachute, the margins of safety were calculated to be 3.2 and 2.5 for the canopy cloth and suspension lines, respectively. The weight of the pilot parachute was estimated at approximately $0.1 \mathrm{lbm}$. Construction details of the pilot parachute can be found on draft drawings included in Appendix A.

\section{Other System Components}

The main parachute is packed into a two-leaf bag that allows high pack densities to be achieved. Details of the bag construction can be found on draft drawings included in Appendix A. The bag is laced together as shown in Figure 2. The lacing is cut 
sequentially during deployment to allow the suspension lines and canopy to exit the bag, but force it to do so in an orderly fashion.

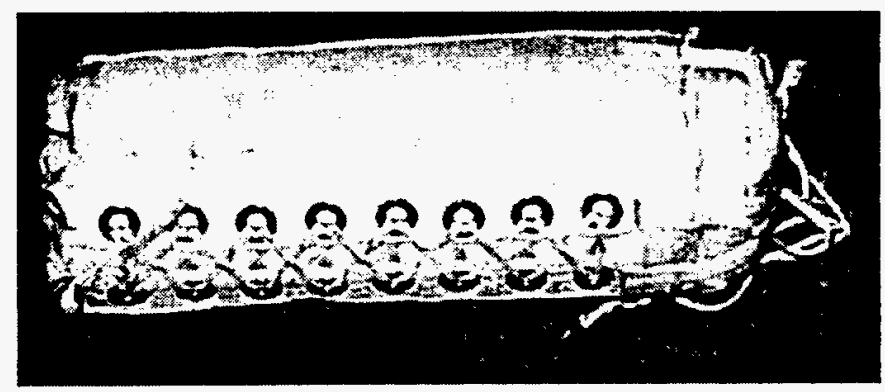

Figure 2. Main and Pilot Parachutes Assembled

The pilot parachute is packed in a "pancake" configuration as shown in Figure 3.

(Drawings for the pilot parachute bag were never developed.) The pilot parachute pack is then restrained to the aft end of the main parachute pack by means of restraint loops and a retaining tie as seen in Figure 2. The retaining tie is cut when the tail-cone is ejected from the aft end, allowing the pilot parachute bag to be pulled free from the main parachute pack.

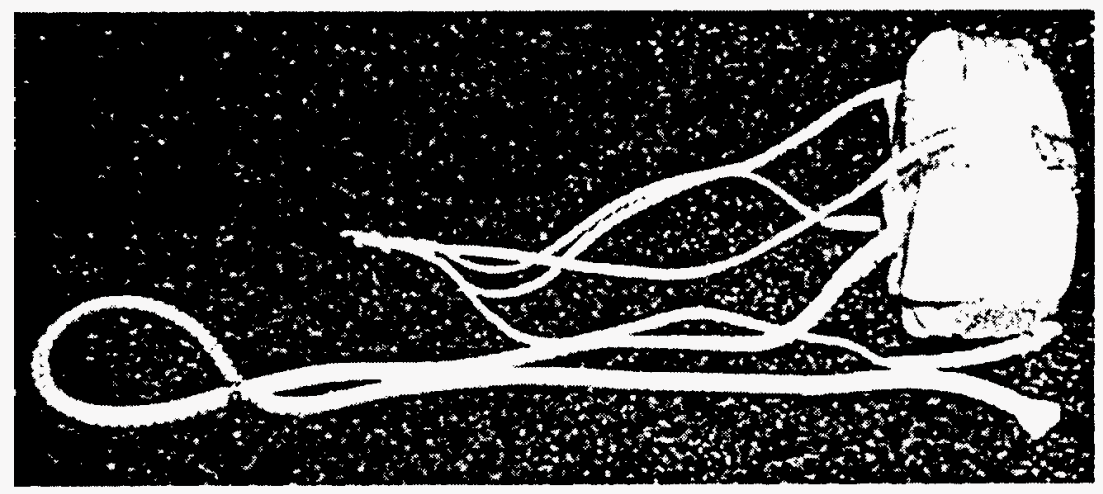

Figure 3. Pilot Parachute Packed in its Bag

The pilot parachute is connected to the main parachute bag handles via a 10 -ft-long towline. This minimizes the wake effects of the penetrator forebody on the performance of the pilot parachute. The towline is made from MIL-C-7515, Type IV, $1000 \mathrm{lb}$-brkg-str braided nylon cord. This selection of material yields a margin of safety of 0.46 based upon the initial estimate of $312 \mathrm{lbf}$ as the maximum developed pilot parachute load.

The confluence of the main parachute suspension lines forms a loop that allows it to be connected to a bridle placed around the TM package. This bridle is manufactured from Kevlar webbing to very close tolerances. This assures that it fits around the TM package and that the assembly fits into the tube that houses the TM package and parachute system, but does not allow the TM package to slip out of the bridle during the extreme accelerations experienced upon deployment. The construction details of the bridle can be found on draft drawings of the bridle included in Appendix A. The bridle can be seen in 
Figure 4 installed around a dummy TM package (no TM antenna is in place on the top of the dummy TM package).

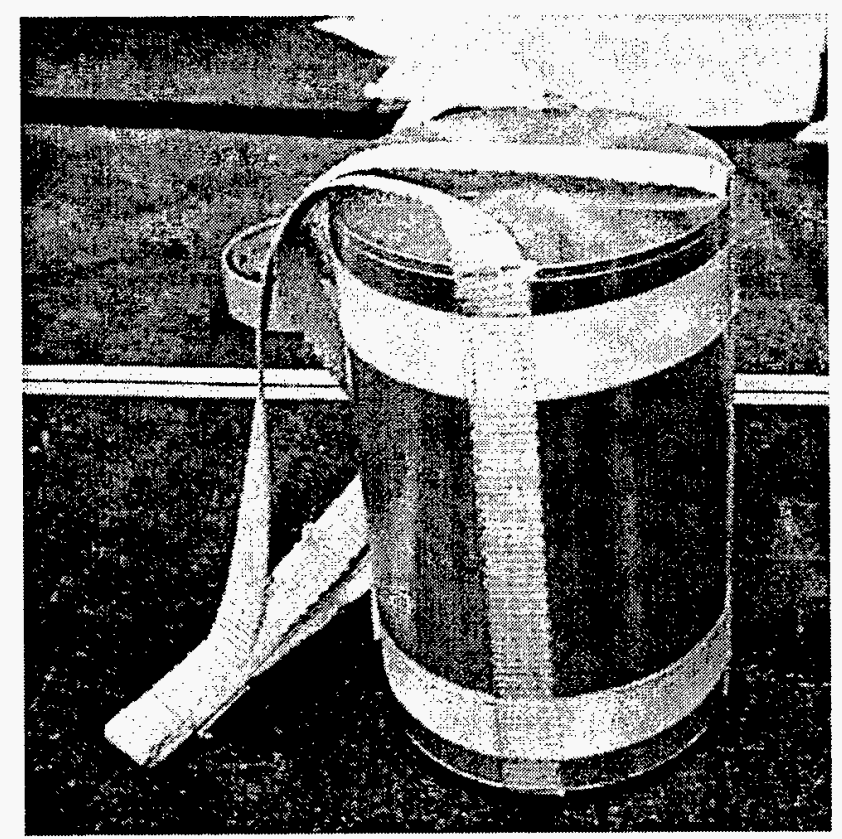

Figure 4. Dummy Telemetry Package Installed in its Bridle (no TM antenna present)

No formal packing manual was developed for the parachute system. A draft of a packing checklist was developed and is included in Appendix B. The procedure for attaching the parachute system to the TM package and installing it into the housing tube was documented in draft form and is included in Appendix B. 


\section{TRAJECTORY ANALYSIS/EVENT TIMING}

The intended sequence of events for function of the WBS parachute system is as follows. Upon sensing the preset initiation altitude, the proximity sensor, initiates the firing of explosive bolts that retain the tail-cone. Upon explosive bolt firing, springs force the tail-cone off which, in turn, deploys the pilot parachute. The pilot parachute then inflates and subsequently deploys the main parachute. The main parachute inflates, extracts the TM package from the weapon, and begins to continuously deploy the wire from the dispenser.

With the exception of the main canopy filling and TM package/wire deployment, each of the events can be considered to occur serially, and the timing and altitude loss for each event can be estimated separately. Timing for some of the events can be estimated using simple calculations. Estimating the timing of events for the main parachute filling and TM package/wire deployment combined event required a complex calculation. As mentioned earlier, the inertial loads resulting from spooling wire from the wire dispenser on the penetrator contribute significantly to the force on the parachute. These inertial forces are highly dependent upon the rate at which the parachute decelerates the TM package which, in turn, is a function of how fast the parachute inflates. An existing computer code called DEPLOYS, originally written to model deployment of parachute suspension lines, was modified to model the wire deployment process. This was necessary since as originally written, the computer code modeled suspension lines being deployed from a parachute pack, whereas in the case of the WBS, the wire deploys from the forebody.

After the first few computer runs, it was realized that another modification to the computer code was required. As originally written, a filling time was entered for the parachute canopy. This is appropriate when the added mass of the air in the canopy is small or comparable as compared to the mass of the payload. In that instance, a fill time can be calculated based upon a nominal number of diameters of travel by the payload and the payload velocity. However, in the case of the WBS TM package, the required parachute diameter results in a very large included air mass in the canopy as compared to the weight of the TM package. This means the parachute decelerates drastically during the inflation process. In this instance it is more accurate to calculate the canopy filling process based upon the fraction of the nominal fill distance that the canopy has actually traveled. With this modification a more accurate calculation of the timing of events could be performed.

\section{Tail-Cone Ejection/Pilot Parachute Deployment}

An estimate of the tail-cone ejection velocity was made based upon the stored energy in the springs and the mass to be ejected. The energy stored in the springs can be found from simple spring theory as:

$$
E_{\text {spring }}=\frac{1}{2} n_{\text {springs }} k x^{2}
$$


where:

$$
\begin{array}{ll}
E_{\text {spring }} \text { is the energy stored in the springs, } \\
n_{\text {springs }} \text { is the number of springs, } \\
k \quad \text { is the spring constant of an individual spring, and } \\
x \quad \text { is the amount the springs are compressed. }
\end{array}
$$

Recalling the formula for the kinetic energy of an object, the velocity can be solved for in terms of the mass of the object and the kinetic energy as follows.

$$
V_{\text {tail-cone }}=\sqrt{\frac{2 E_{\text {spring }}}{m_{\text {tail }- \text { cone }}}}
$$

where:

$$
\begin{aligned}
& V_{\text {tail-cone }} \text { is the velocity of the tail-cone, and } \\
& m_{\text {tail-cone }} \text { is the mass of the tail-cone. }
\end{aligned}
$$

The initial values supplied for the springs were a spring constant of $38 \mathrm{lbf} / \mathrm{in}$ and 1.7 inches of compression. This results in $18.3 \mathrm{ft}-\mathrm{lbf}$ of stored energy. The initial estimate of the tail-cone mass was $6 \mathrm{lbm}$. Using this estimate of stored energy and mass, and ignoring any aerodynamic drag, when released the tail-cone should achieve a velocity of $14 \mathrm{ft} / \mathrm{sec}$. This ejection process (just to release the compression in the springs) should occur over $0.016 \mathrm{sec}$. Subsequent explosive bolts tests indicated that the tail-cone would be ejected at $\sim 20 \mathrm{fps}$. This increase in velocity could be a result of additional energy being imparted to the tail-cone due to the explosive bolts themselves. Since the forebody is travelling at nearly $1000 \mathrm{fps}$, it was estimated that there would be $16 \mathrm{ft}$ of altitude loss during the process of ejecting the tail cone via the explosive bolts and springs.

Once the springs have released and the tail cone is free from the weapon, aerodynamic forces will take over and further accelerate the tail-cone and deploy the pilot parachute. This will all occur in the wake of the weapon. However, in absence of anything more accurate, free stream dynamic pressure will be used to estimate the timing of this event. The tail-cone has a flat adapter plate affixed to the inside at nearly the front edge. Thus, it can be estimated to have a drag area of a flat circular disk ${ }^{3}$ with a drag coefficient of 1.17. The base of the tail-cone is 12 inches in diameter resulting in a drag area of $0.92 \mathrm{ft}^{2}$.

This drag area and the mass increments associated with deploying the pilot parachute were input into the DEPLOYS computer code referred to earlier. The estimate for the time to reach pilot parachute canopy stretch (the time the parachute is completely deployed and ready to start inflating) was calculated as $0.082 \mathrm{sec}$. In this time, the 
forebody has traveled $74 \mathrm{ft}\left(71 \mathrm{ft}\right.$ of altitude loss at a flight path angle of $\left.75^{\circ}\right)$, and no wire has yet to be deployed.

\section{Pilot Parachute Inflation/Main Parachute Deployment}

As mentioned earlier, the DEPLOYS code was modified to use filling distance instead of time to more accurately model the canopy filling process for comparatively light payloads. The pilot parachute has a nominal diameter, $D_{o}$, of $1.28 \mathrm{ft}$. The filling distance for a parachute is commonly considered to be a multiple of its nominal diameter so that we can write:

$$
d_{\text {fill }}=n_{\text {fill }} D_{o}
$$

where:

$$
\begin{array}{ll}
d_{\text {fil }} & \text { is the filling distance and } \\
n_{\text {fill }} & \text { is the filling constant. }
\end{array}
$$

For a cross parachute, the filling constant has been identified as $11.7^{4}$. Given the empirical nature of this constant, it was rounded to a factor of 12, and Equation (11) yields a filling distance of $15 \mathrm{ft}$.

The other input needed for the DEPLOYS code is the mass distribution of the parachute being deployed - in this case the main parachute. An estimate for the suspension line and canopy mass can be obtained by using the maximum specification weights for suspension line and canopy materials. For the materials mentioned earlier, the main parachute suspension line mass should be about $1.1 \mathrm{lbm}$ equally distributed over the length of 13.5 $\mathrm{ft}$. The canopy mass is estimated as $2.2 \mathrm{lbm}$ and is assumed to be equally distributed over half of the canopy's constructed diameter of $10.8 \mathrm{ft}$.

The DEPLOYS code calculations estimate that the pilot parachute will be fully inflated in 0.018 seconds and will have deployed the main parachute to canopy stretch in 0.091 seconds. In this time the forebody has traveled $82 \mathrm{ft}$ and experiences $80 \mathrm{ft}$ of altitude loss (for a $75^{\circ}$ flight path angle). The only resistive forces on the suspension lines are due to the inertial loads of the TM package. Since it has a mass of only $10 \mathrm{lbm}$, it will most likely move some during the process of deploying the main parachute. Thus, another calculation was made using a $10-\mathrm{lbm}$ forebody. The forebody travel distance was then compared to the original calculation for the penetrator to determine how much the TM package traveled with respect to the penetrator forebody and hence how much wire was dispensed. The results were that the TM package had moved about $1.5 \mathrm{ft}$ relative to the forebody, dispensing a like amount of wire. The TM package had also decelerated from an initial velocity of $900 \mathrm{fps}$ (delivery velocity of the weapon) to $819 \mathrm{fps}$. This turns out to be a necessary input to the next phase of the calculation - main parachute inflation/TM package deceleration/wire dispensing. 


\section{Main Parachute Inflation/TM package Deceleration/Wire Dispensing}

Using Equation (11), a filling constant of 12 (the main parachute is also a cross parachute), and a nominal diameter of $8.7 \mathrm{ft}$ yields a fill distance of $104 \mathrm{ft}$ for the main canopy. Using this as input, the special version of the DEPLOYS code was used that models the "suspension lines" deploying from the forebody, rather than the more typical deployment from a parachute deployment bag. Thus, the wire deploying from the dispenser could be modeled. The wire design had been finalized by this time and the actual density of $3.8 \mathrm{lbm} / 1000 \mathrm{ft}$ was used for the calculation.

The forebody was calculated to hit the ground 0.61 seconds after the beginning of this phase of the calculations. The initial altitude utilized for the entire suite of calculations was $700 \mathrm{ft}$ AGL. At the time of impact, the velocity of the parachute/TM package combination was $50 \mathrm{fps}$, whereas that of the forebody was $902 \mathrm{fps}$. This means the wire would be moving relative to the ground at $50 \mathrm{fps}$ and spooling from the dispenser at 852 fps at the time of impact. The tension in the wire is at a maximum just below the TM package, occurs at the time of impact, and was calculated to be $83 \mathrm{lbf}$. The canopy of the main parachute was calculated to not have completely filled by the time of impact, having only achieved $80 \%$ of its full open drag area.

\section{Full Trajectory Summary and Parametric Variations}

The travel distance of both the forebody and the TM package, along with the amount of line deployed and the velocity of the wire with respect to the ground, are shown in Figure 5. The entire trajectory can be found in tabular form in Appendix C. These are the nominal values.

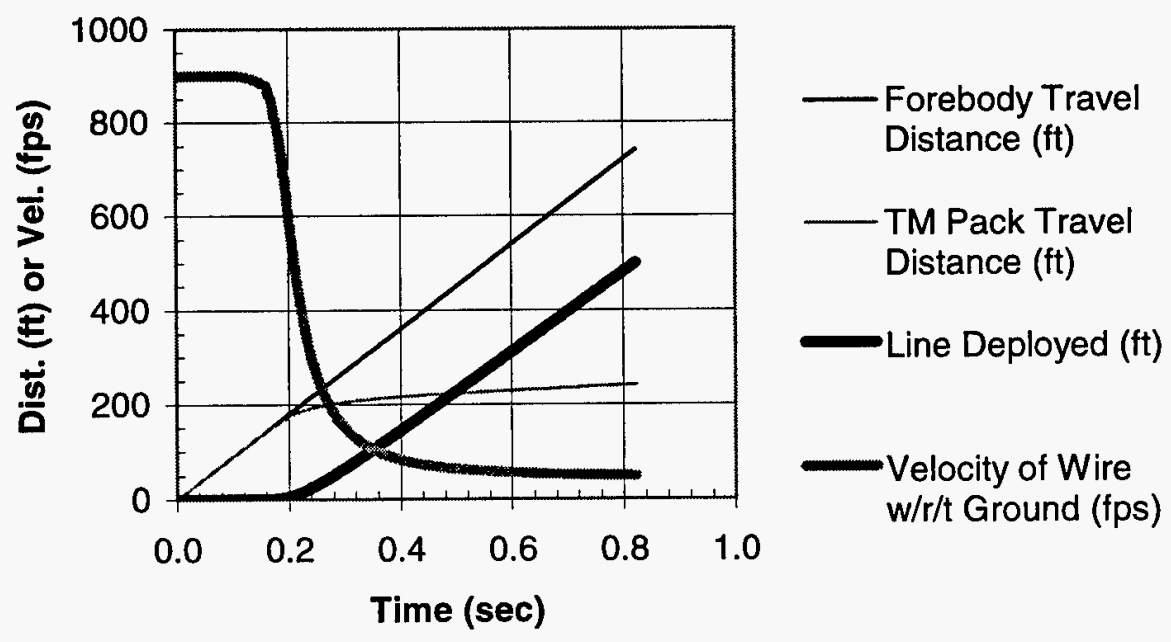

Figure 5. Weapon Borne Sensor Trajectory Parameters

Given the high velocity of the weapon, small variations in timing could result in significant variations in amount of wire deployed before impact. Variations in parachute 
inflation parameters could also impact the amount of time the TM package was clear of the tail section and available for acquisition of signal. Initial estimates indicated that the available acquisition time for the nominal trajectory would already be marginal. An attempt was made to bound the problem by looking at two different off-nominal cases -the "Slow" and "Fast" deployment cases. In the "Slow" case, the variations in parameters are considered that would produce smaller amounts of line deployed and shorter amounts of time for the TM package to be clear of the tail section. In the "Fast" case, parameter variations were considered that would produce larger amounts of line deployed and longer available times for TM acquisition before impact.

The personnel developing the proximity sensor estimated its accuracy to be $\pm 10 \%$ about the nominal trigger altitude of $700 \mathrm{ft}$ AGL. Thus, in the "Slow" bounding case, an initiation altitude of $630 \mathrm{ft}$ was considered, since that would produce smaller amounts of wire being dispensed and shorter acquisition times for the TM signal. Conversely, $770 \mathrm{ft}$ was used for the "Fast" case. The delivery velocity can be a function of weapon release altitude and target altitude. The customer supplied the nominal value of $900 \mathrm{fps}$ and the bounds of \pm 100 fps.

The tail cone mass and the energy in the ejection springs determine the tail cone ejection velocity. The system-integrating contractor, Applied Research Associates (ARA), estimated the nominal tail cone weight to be $6 \mathrm{lbm}$, with a $+2 /-1 \mathrm{lbm}$ variation as reasonable bounds. A variation in the spring constant of $\pm 15 \%$ was assumed. Using these values, the nominal ejection time of the tail cone was calculated, as shown previously, to be 0.016 seconds. Using the bounding values of tail cone mass and spring constant, the bounding values of 0.020 and 0.013 seconds were calculated for the tail cone ejection time. The corresponding ejection velocities were 11 and 16 fps.

Variations in tail cone drag area and the main and pilot parachute masses of $\pm 15 \%$ were assumed. The pilot and main parachute filling constants were considered to vary by \pm 2 diameters about the nominal value of 12 , yielding the bounding values of 14 and 10 . The pilot and main parachute drag areas, main parachute mass, and the wire density and break-out force were varied by $\pm 15 \%$. The parametric variations used for the bounding calculations can be seen in Table 1 . These bounding values were used in calculations by the DEPLOYS code to bound the timing and dispensed wire amounts. The elapsed time, altitude loss, and amount of wire deployed for various events is shown in Table 2 for the "Slow", Nominal, and "Fast" deployments. In addition, the velocity of the wire with respect to the ground at the time of forebody impact and the maximum acceleration of the TM package are shown. 
Table 1. Parametric Variations Considered in Input Parameters for Trajectory Calculations

\begin{tabular}{|c|c|c|c|c|c|c|c|c|c|c|c|c|c|c|c|}
\hline & 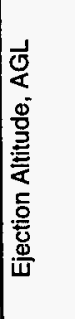 & $\begin{array}{l}\frac{2}{0} \\
\frac{0}{0} \\
\frac{0}{2} \\
\frac{0}{0} \\
\frac{5}{0} \\
>0\end{array}$ & 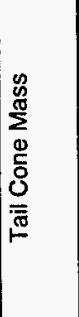 & 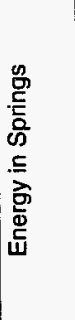 & 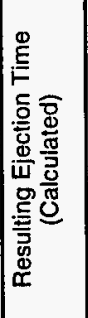 & 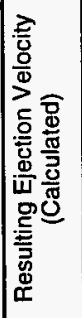 & 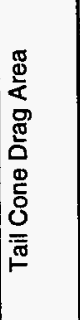 & 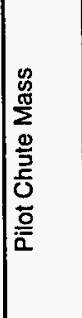 & 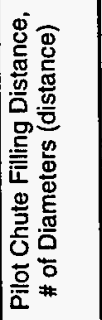 & 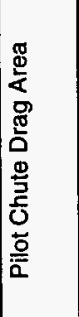 & 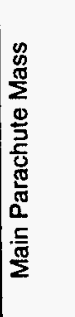 & 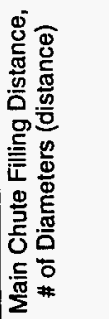 & 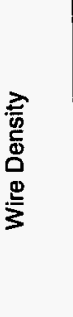 & 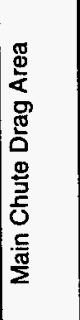 & 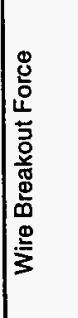 \\
\hline & $\Phi$ & 高 & $\hat{\mathrm{E}}$ & 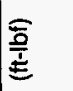 & $\begin{array}{l}\text { D } \\
\text { 怘 } \\
.\end{array}$ & 总 & 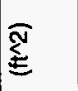 & $\begin{array}{l}\bar{E} \\
\underline{\underline{E}}\end{array}$ & $\underset{ \pm}{ \pm}$ & 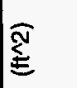 & $\underline{\underline{E}}$ & $\begin{array}{l} \pm \\
5\end{array}$ & $\underset{\text { E }}{\stackrel{E}{E}}$ & $\stackrel{\mathbb{N}}{\Xi}$ & $\widehat{\bar{\Xi}}$ \\
\hline Variation considered & $10 \%$ & 100 & $+2 /-1$ & $15 \%$ & - & - & $15 \%$ & $15 \%$ & $2,-$ & $15 \%$ & $15 \%$ & 2 & $15 \%$ & $15 \%$ & $15 \%$ \\
\hline "Slow" & 630 & 1000 & 8 & 15.6 & 0.020 & 11 & 0.78 & 0.25 & $14(18)$ & 0.78 & 3.8 & $14(122)$ & 4.4 & 41 & 3.5 \\
\hline Nominal & 700 & 900 & 6 & 18.3 & 0.02 & 14 & 0.90 & 0.22 & $12(15)$ & 0.92 & 3.3 & $12(104)$ & 3.8 & 48 & 3 \\
\hline "Fast" & 770 & 800 & 5 & 21 & 0.01 & 16.5 & 1.06 & 0.18 & $10(13)$ & 1.06 & 2.8 & $10(87)$ & 3.2 & 55 & 2.6 \\
\hline
\end{tabular}

Table 2. Variations in Trajectory Parameters from Input Variable Parametric Study

\begin{tabular}{|c|c|c|c|c|c|c|c|c|c|}
\hline \multirow[b]{2}{*}{ Time Period } & \multicolumn{3}{|c|}{ Elapsed Time } & \multicolumn{3}{|c|}{ Altitude Loss } & \multicolumn{3}{|c|}{ Wire Deployed } \\
\hline & "Slow" & Nominal & "Fast" & "Slow" & Nominal & "Fast" & "Slow" & Nominal & "Fast" \\
\hline $\begin{array}{l}\text { Tail Can Ejection to } \\
\text { End of Spring Stroke }\end{array}$ & 0.020 & 0.016 & 0.013 & 20 & 14 & 11 & - & $\cdot$ & $=$ \\
\hline $\begin{array}{l}\text { Pilot Chute Deployed to } \\
\text { Canopy Stretch }\end{array}$ & 0.090 & 0.082 & 0.081 & 87 & 71 & 63 & - & - & $\cdot$ \\
\hline Pilot Chute Fill & 0.019 & 0.018 & 0.017 & 18 & 16 & 13 & - & - & - \\
\hline $\begin{array}{l}\text { Main Canopy Deployed to } \\
\text { Canopy Stretch }\end{array}$ & 0.078 & 0.076 & 0.078 & 72 & 64 & 58 & 1 & 1 & 1 \\
\hline $\begin{array}{r}\text { TM Package } 110 \% \text { of } \\
\text { Terminal Velocity }\end{array}$ & 0.36 & 0.44 & 0.53 & 352 & 385 & 408 & 279 & 323 & 359 \\
\hline TM-Out to Impact & 0.45 & 0.61 & 0.80 & & & & & & \\
\hline Release to Impact & 0.66 & 0.8 & 0.99 & 630 & 700 & 770 & 356 & 465 & 571 \\
\hline & "Slow" & Nominal & "Fast" & & & & & & \\
\hline $\begin{array}{l}\text { Velocity of Wire w/r to } \\
\text { Ground at Impact (fps) }\end{array}$ & 68 & 50 & 37 & & & & & & \\
\hline $\begin{array}{r}\text { Maximum Acceleration } \\
\text { on TM! Pack ( } g \text { 's) }\end{array}$ & 320 & 328 & 333 & & & & & & \\
\hline
\end{tabular}


The acceleration of the TM package in excess of $300 \mathrm{~g}$ 's disturbed the personnel developing that component. Thus, another series of computer runs were made in an attempt to reduce the maximum acceleration by reducing the size of the parachute. The drag area of the main parachute was reduced to $60 \%$ of the drag area of the nominal case. This resulted in a reduction in the maximum acceleration to $277 \mathrm{~g}$ 's, but also increased the velocity of the wire at the time of impact to $58 \mathrm{fps}$. Four options were considered at this point:

1) Leave the system design as originally proposed and expect the TM system to withstand the short-lived high-acceleration pulse,

2) Reduce the main parachute size at the expense of greatly increased wire velocity,

3) Reef the main parachute momentarily to limit the drag area at first and thereby reduce the acceleration loads on the TM system, and

4) Ballast the TM package to reduce peak accelerations.

Option 4 was dismissed since the entire system was already exceeding the allowable weight. Option 3 was discounted since very short reefing cutter delay times would be needed (which typically have large variations associated with them) that would lead to large variations in amount of wire dispensed and TM acquisition time. Since the original acceleration pulse was very narrow, the TM package would have to only survive it, not operate in it. Since the threat to wire survivability in option 2 was considered to be too great, option 1 was chosen.

Late in the program the estimate for TM package weight was greatly reduced to $6 \mathrm{lbm}$. There was concern that the lighter TM package would result in attempting to dispense more wire than the dispenser held. This didn't seem likely, since the majority of the load on the parachute is inflicted by the inertial loads of dispensing the wire. However, an additional computer run was made to verify this observation. Indeed, when using a 6-lbm TM package, 472 feet of wire was dispensed compared to the 465 feet estimated for the nominal case. Thus, no changes were made to the parachute system to accommodate the lower estimate of TM weight. (The final weight for the TM package was $6.5 \mathrm{lbm}$.) 


\section{TEST RESULTS}

Two static ejection tests were made of the tail-cone and pilot parachute. In each the tail-cone adequately deployed the pilot parachute. In the first test, a knife lanyard attached to the tail-cone proved to be adequate to cut the electrical ribbon cable that connected the TM package to the proximity sensor and explosive bolts in the tail-cone. Suspicion that this knife could have shorted the electrical cable and led to failure in the first full-scale flight test resulted in a design change. In the revised design, an in-line separable connector was installed in the electrical ribbon cable to eliminate the need for a knife. A second static test, on a unit that had been subjected to a full-scale vibration flyaround test, verified that the tail-cone separation would lead to pilot parachute deployment and cable connector separation.

Two flight tests of the WBS were conducted at Eglin AFB, Florida. Unfortunately, in neither of the tests did the tail-cone deploy before impact. Thus, the parachute system was never deployed and data is not available to verify the calculations. The program was terminated after the second flight and at this time no further work is planned in this area. 


\section{CONCLUSIONS}

A parachute system was designed for the Weapon Borne Sensor to deploy the telemetry (TM) package and signal wire. The major system components include a 19-inch, cross pilot parachute and bag, a 130-inch, cross main parachute and bag, and a bridle for the TM package. It is estimated that when the system is deployed at $700 \mathrm{ft}$ AGL, the TM package will be extracted and free of the tail section for 0.61 seconds prior to impact and experience a maximum of $365 \mathrm{~g}$ 's. The parachute would have extracted 465 feet of wire at the time of impact and the velocity of the wire, with respect to the ground at impact, would be $50 \mathrm{fps}$.

Unfortunately, in neither of the two flight tests that were conducted was there a successful deployment of the tail-cone. The program was terminated after the second flight test. The tail-cone initiates the deployment of the parachute system, thus no comparison of the calculated values to experimental data was possible. If the program were to be resurrected in the future, close attention should be paid to verifying the modeling of the filling process of the two parachutes, especially the main parachute.

One complete system and ten pilot parachutes (packed in their bags) remained at the termination of the program. These assets were returned to the customer upon their request. 


\section{REFERENCES}

${ }^{1}$ Knacke, T. W., Parachute Recovery Systems Design Manual, p 5-3, NWC TP 6575, Naval Weapons Center, China Lake, CA, March1991.

${ }^{2}$ Knacke, T. W., p 5-54.

${ }^{3}$ Hoerner, S. F., Fluid Dynamic Drag, Chap. 3, Fig. 33, p 3-17, published by author, 1965.

${ }^{4}$ Knacke, T. W., p 5-44. 


\section{APPENDICES}

Appendix A: Draft Drawings of Parachute System Components

10.8-Ft-Dia Cross, Main Parachute Drawings 28

Main Parachute Bag Drawings $\quad 40$

1.3-ft-dia Pilot Parachute Drawings $\quad 47$

Telemetry Package Sling Drawings $\quad 56$

Appendix B: WBS Packing and Installation Checklist and Manual 59

WBS Parachute System Packing Checklist 59

WBS Parachute Installation Procedure $\quad 62$

Appendix C: Nominal WBS Trajectory 
Appendix A

Draft Drawings of Parachute System Components 
10.8-Ft-Dia Cross, Main Parachute Drawings 


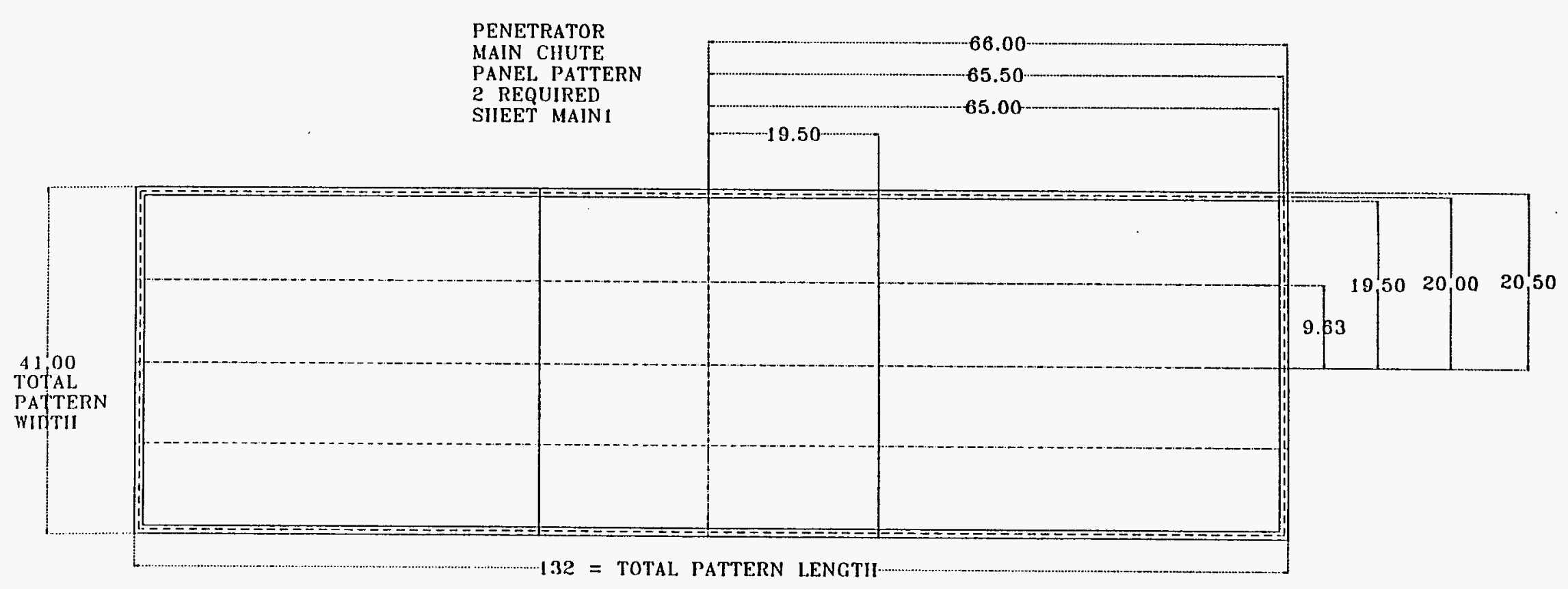




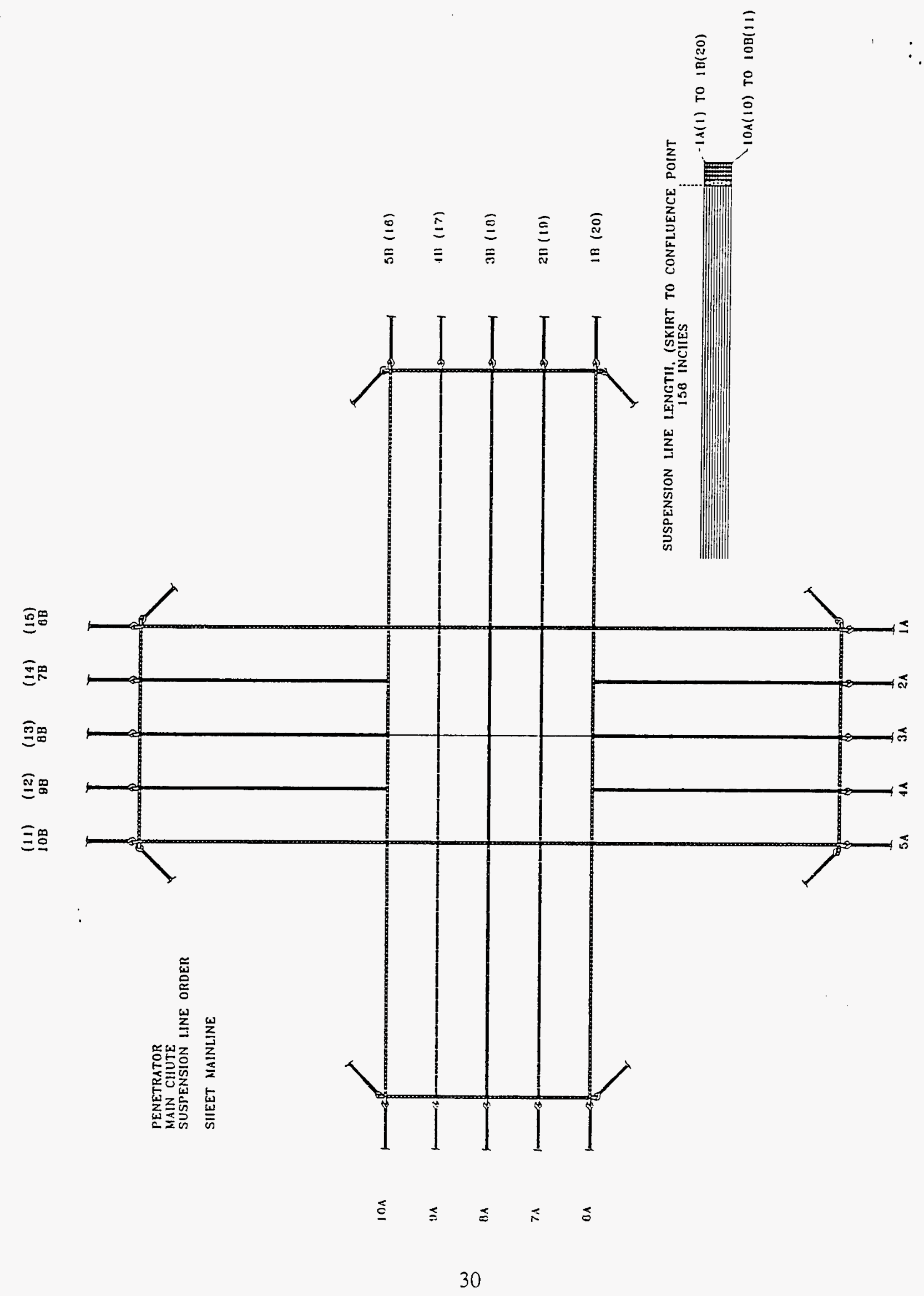




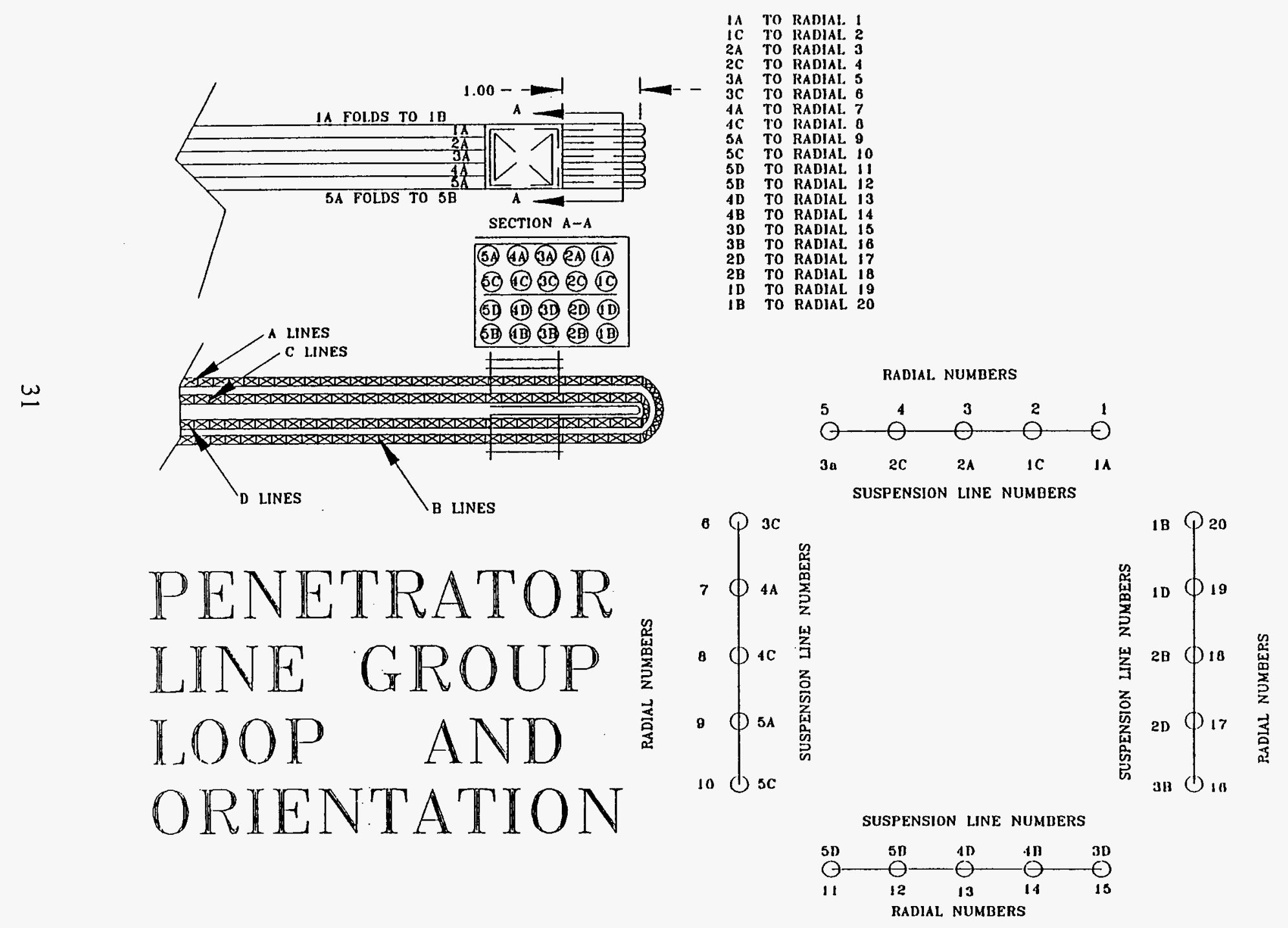




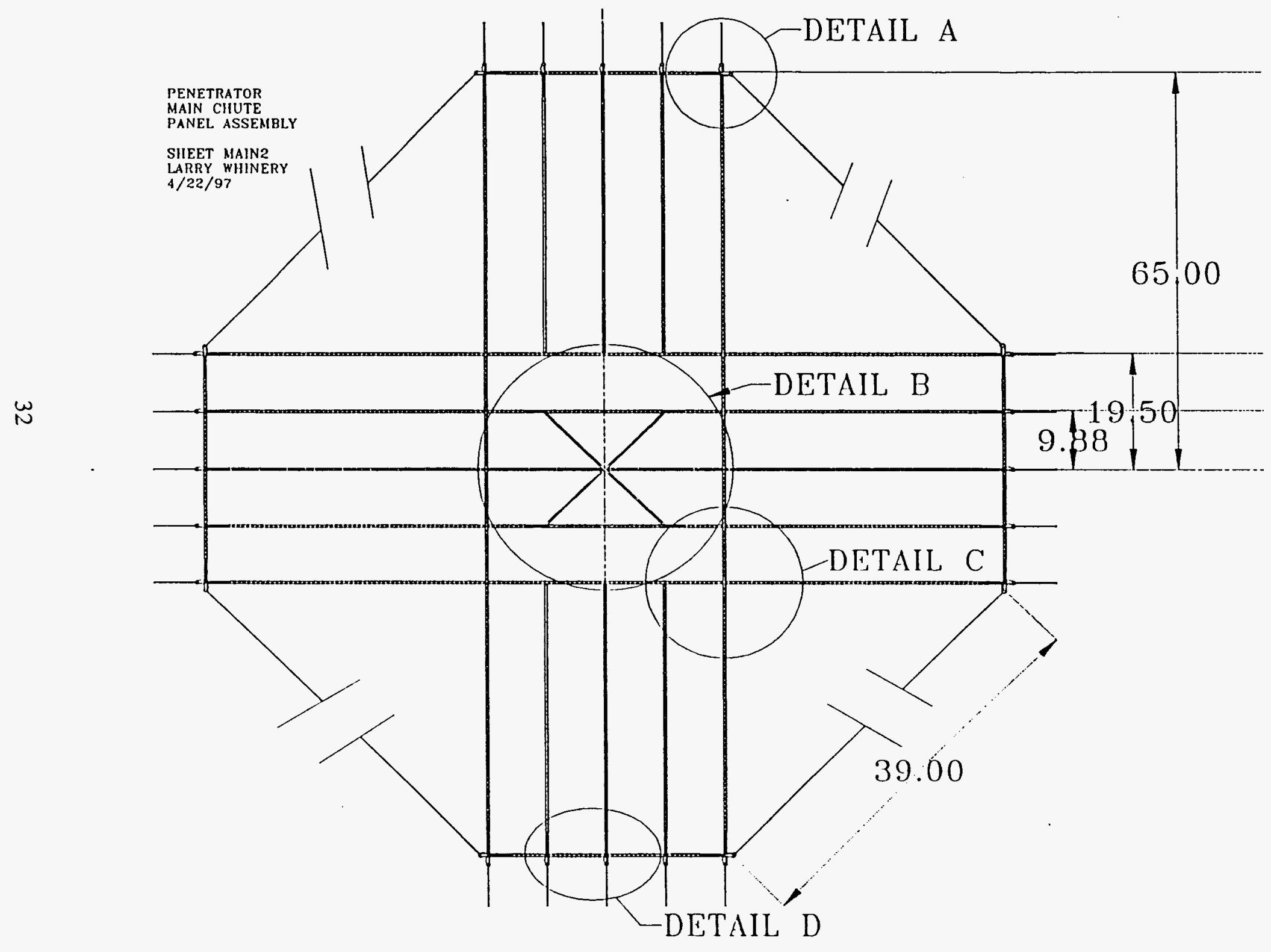




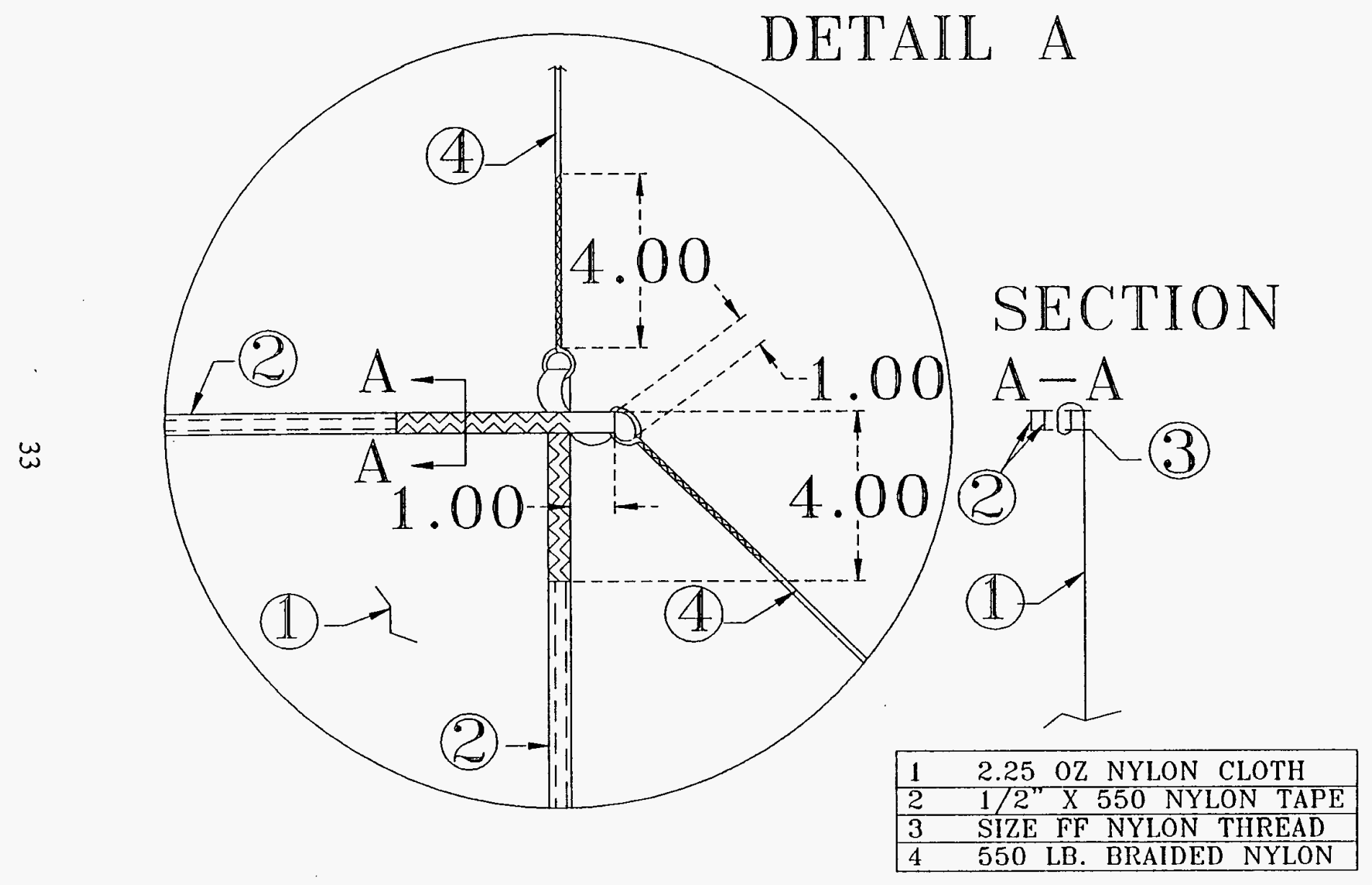




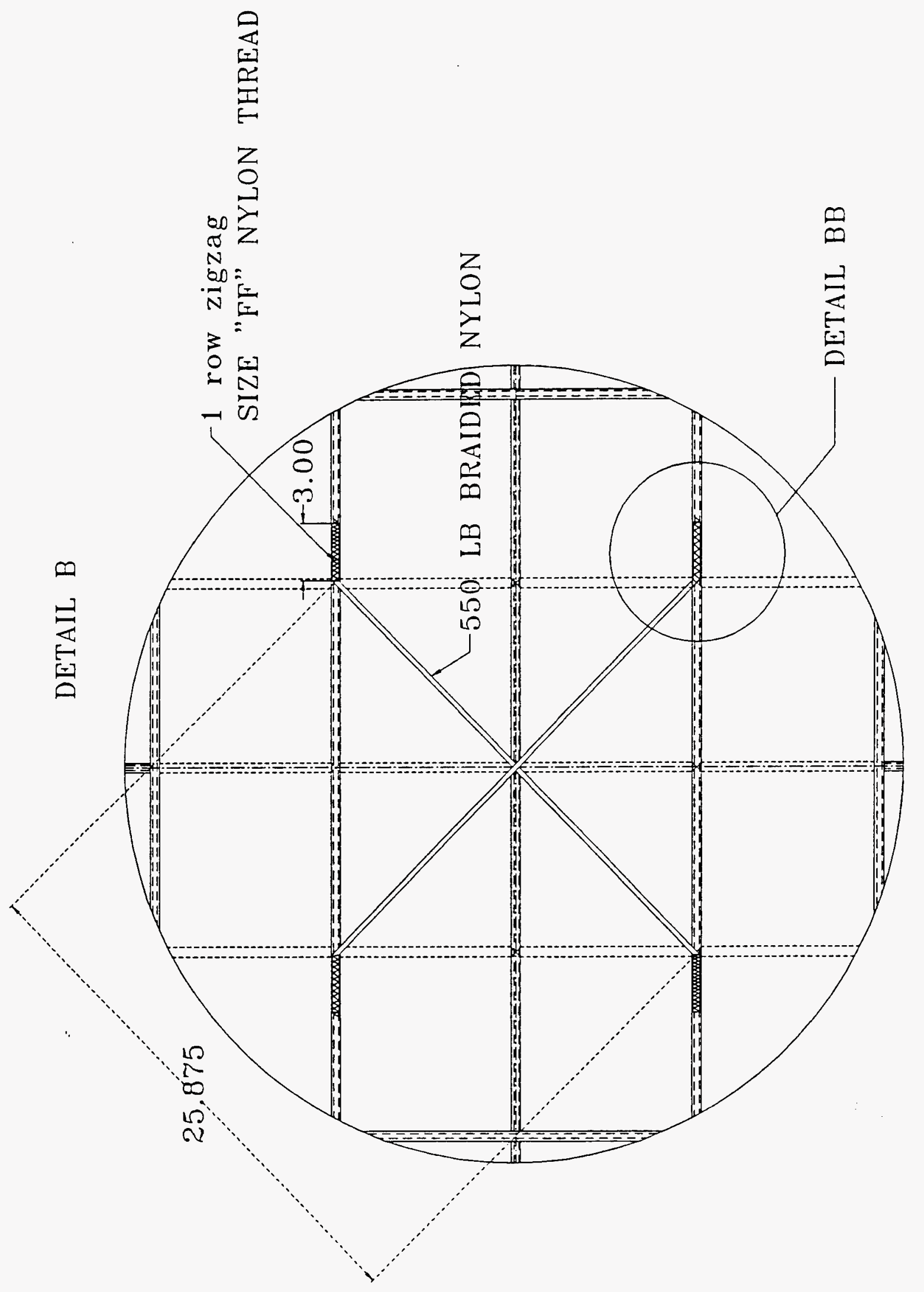




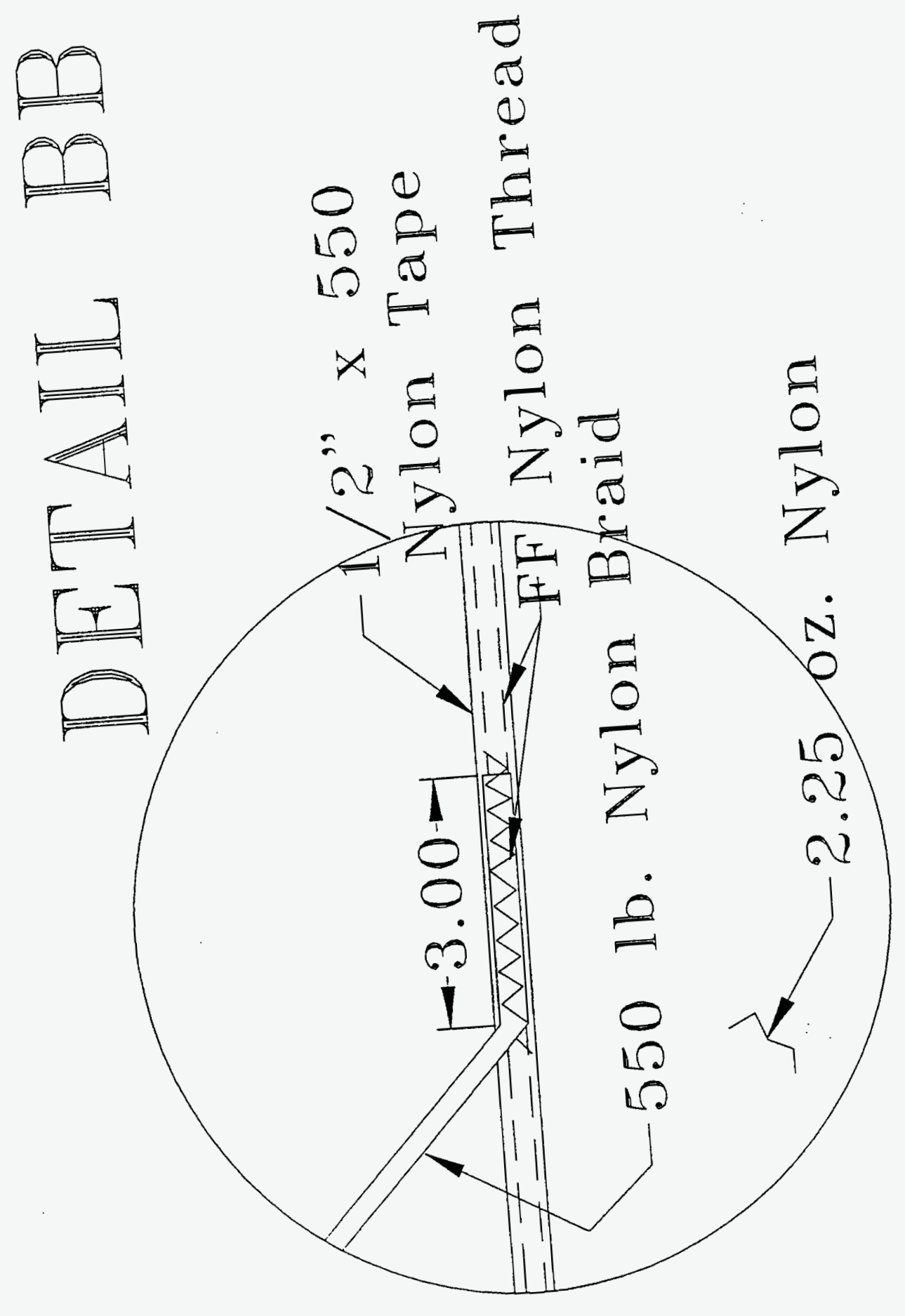




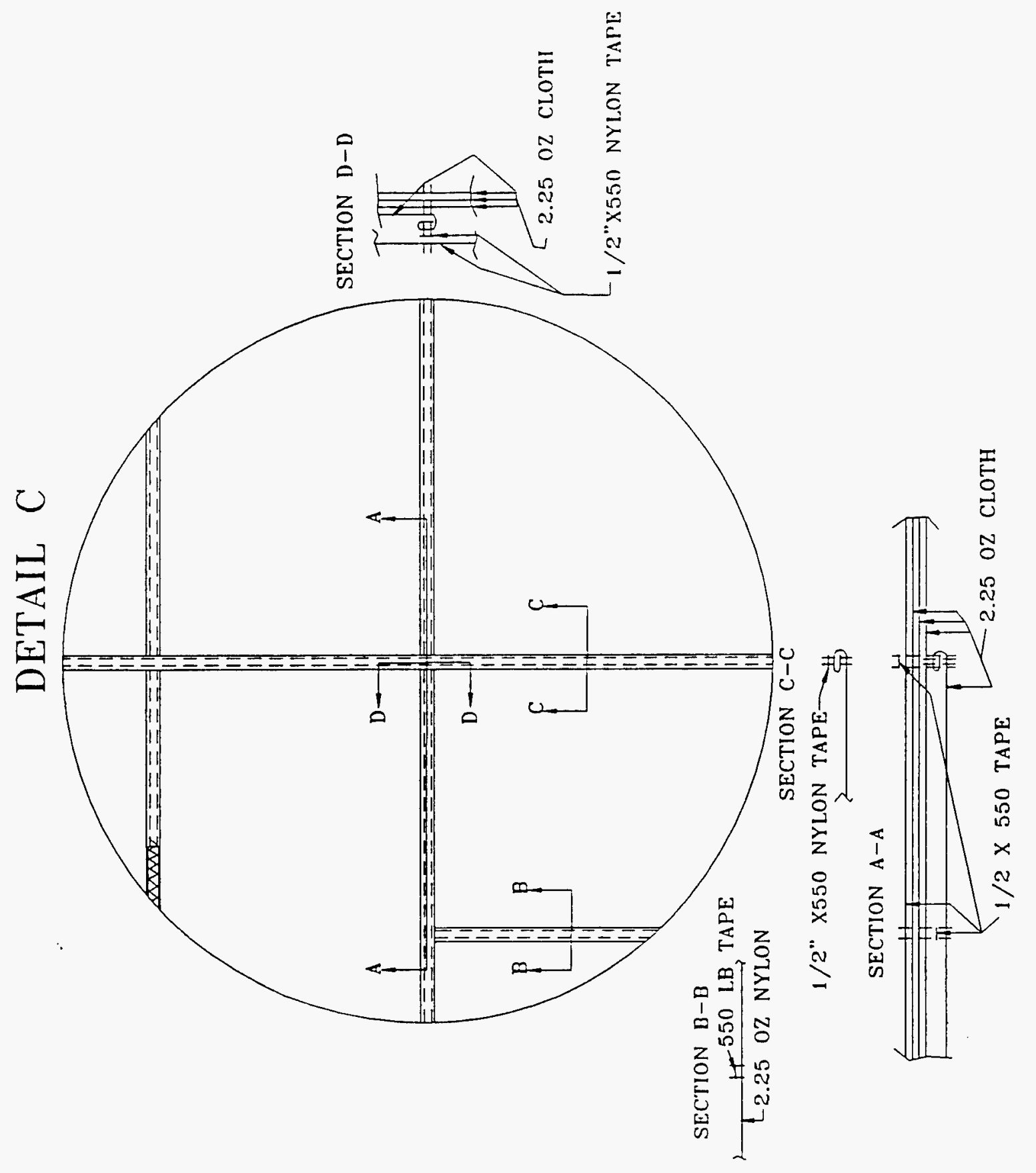




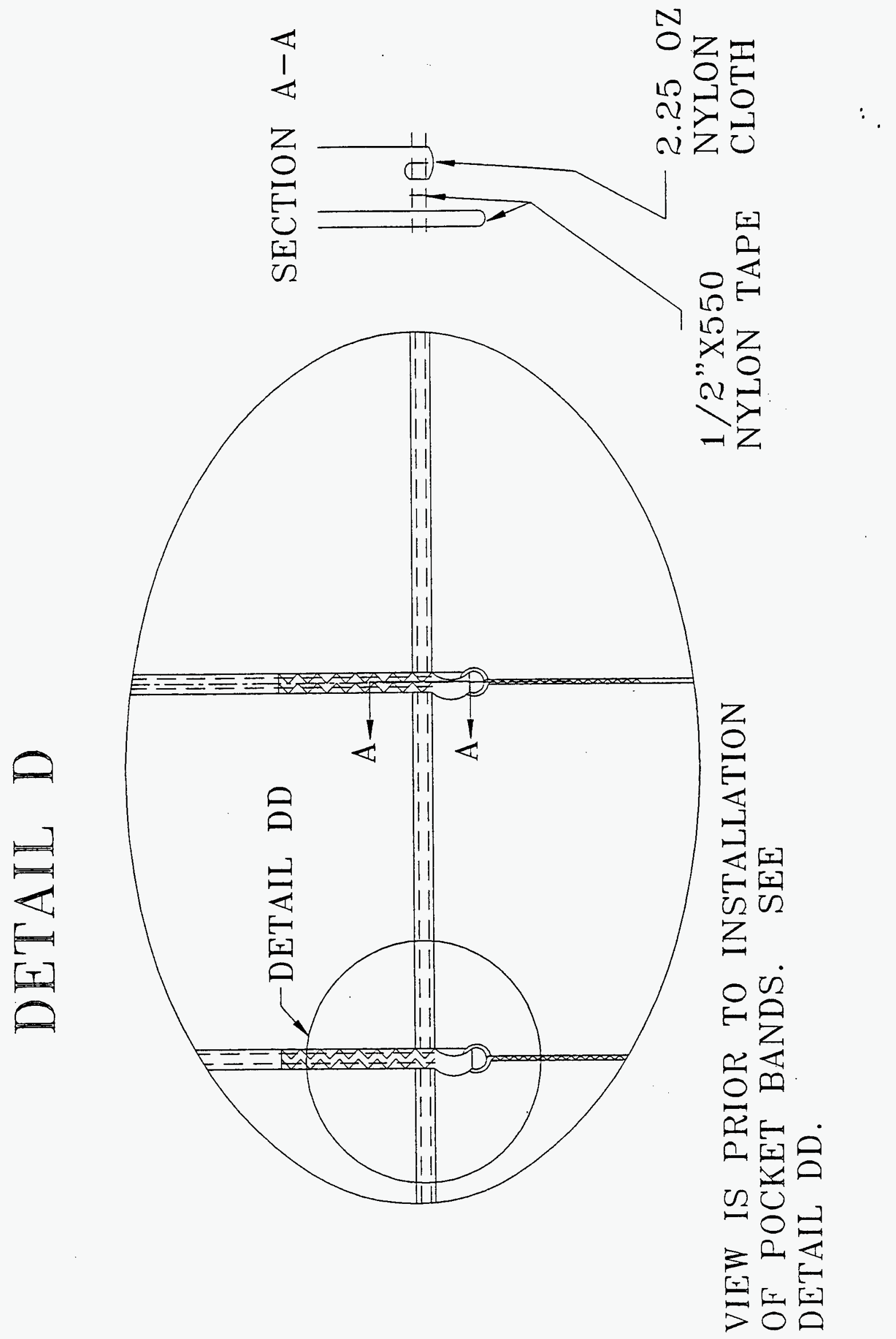




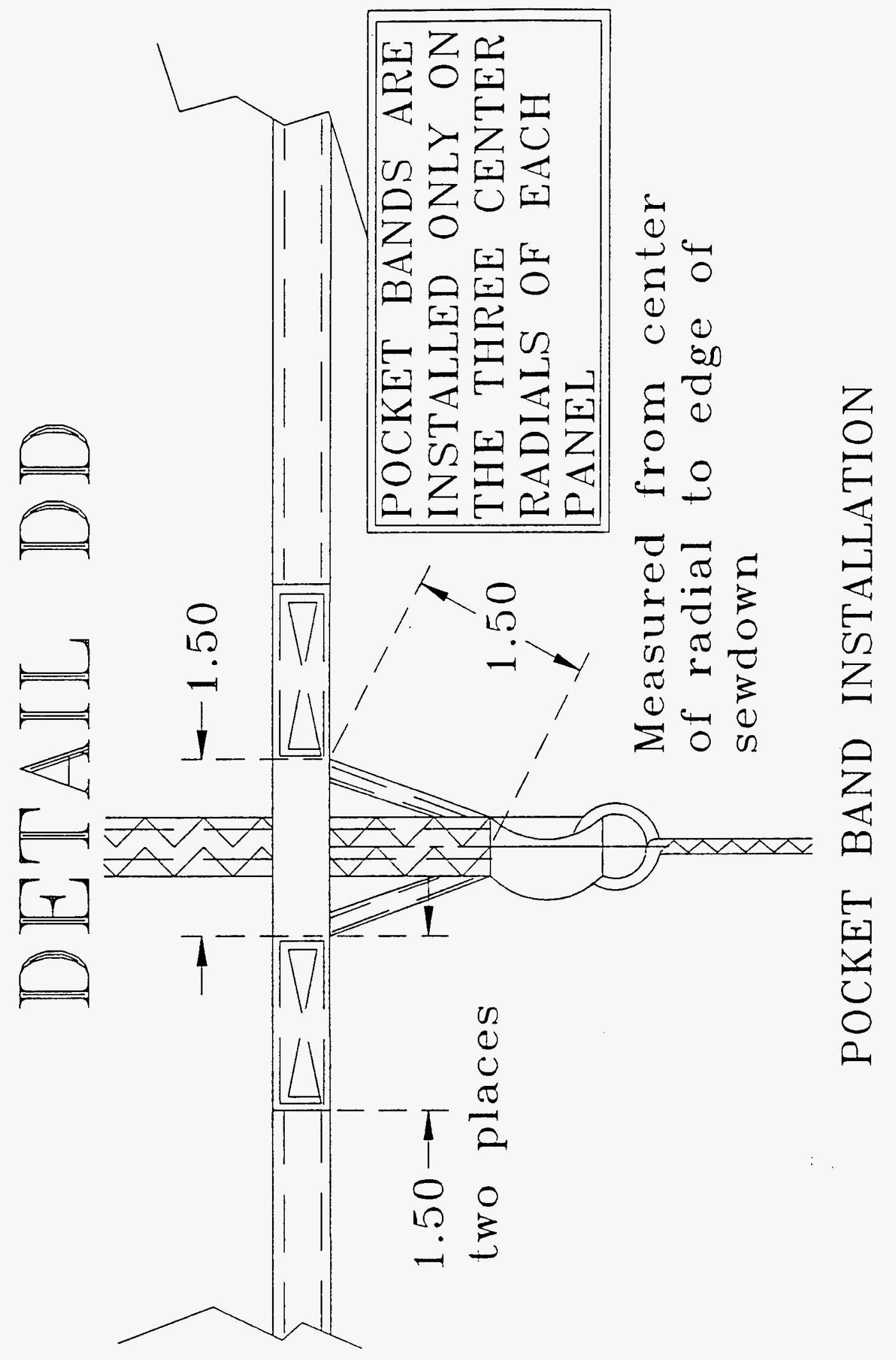


DETAIL E

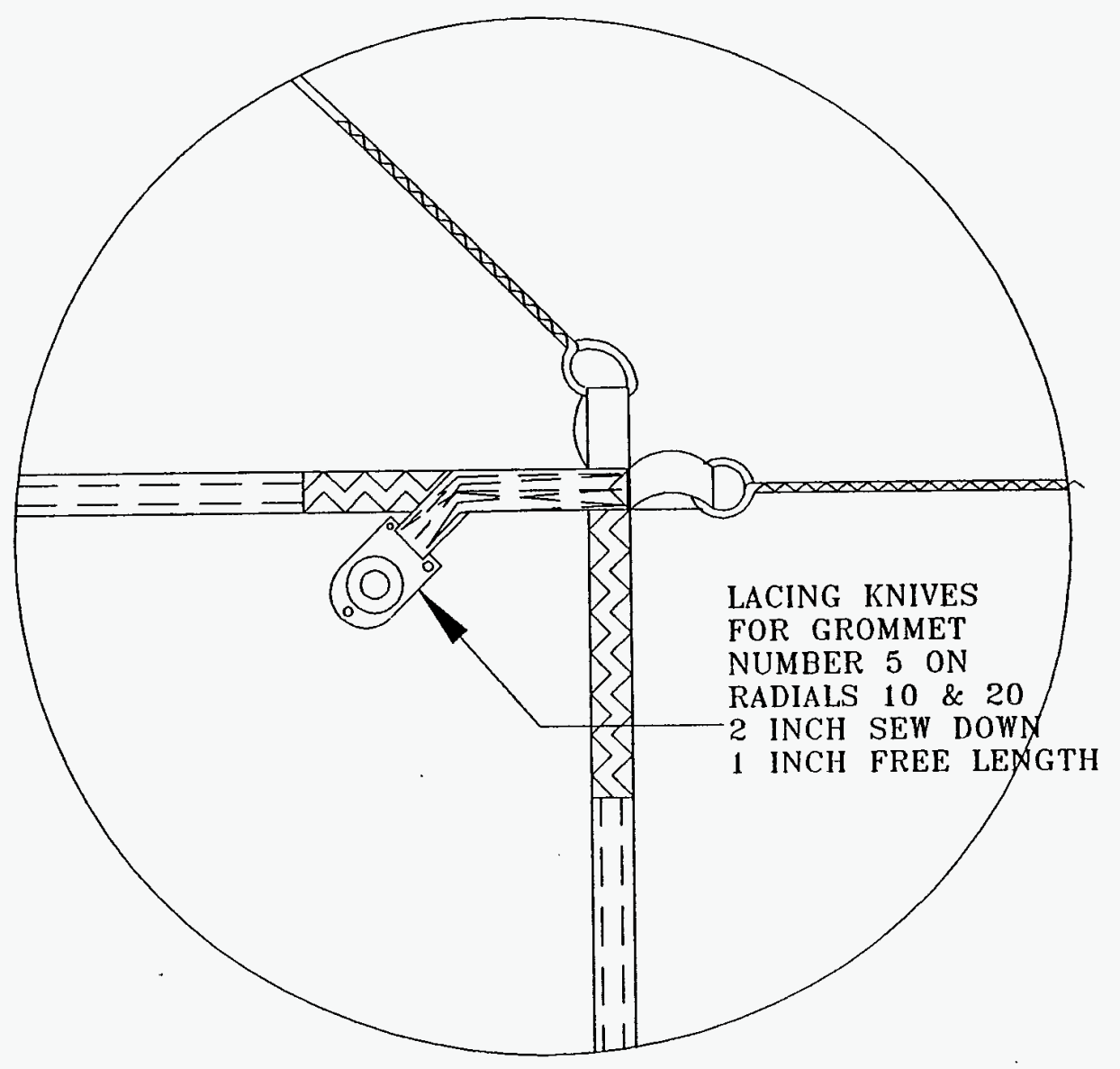


Main Parachute Bag Drawings 


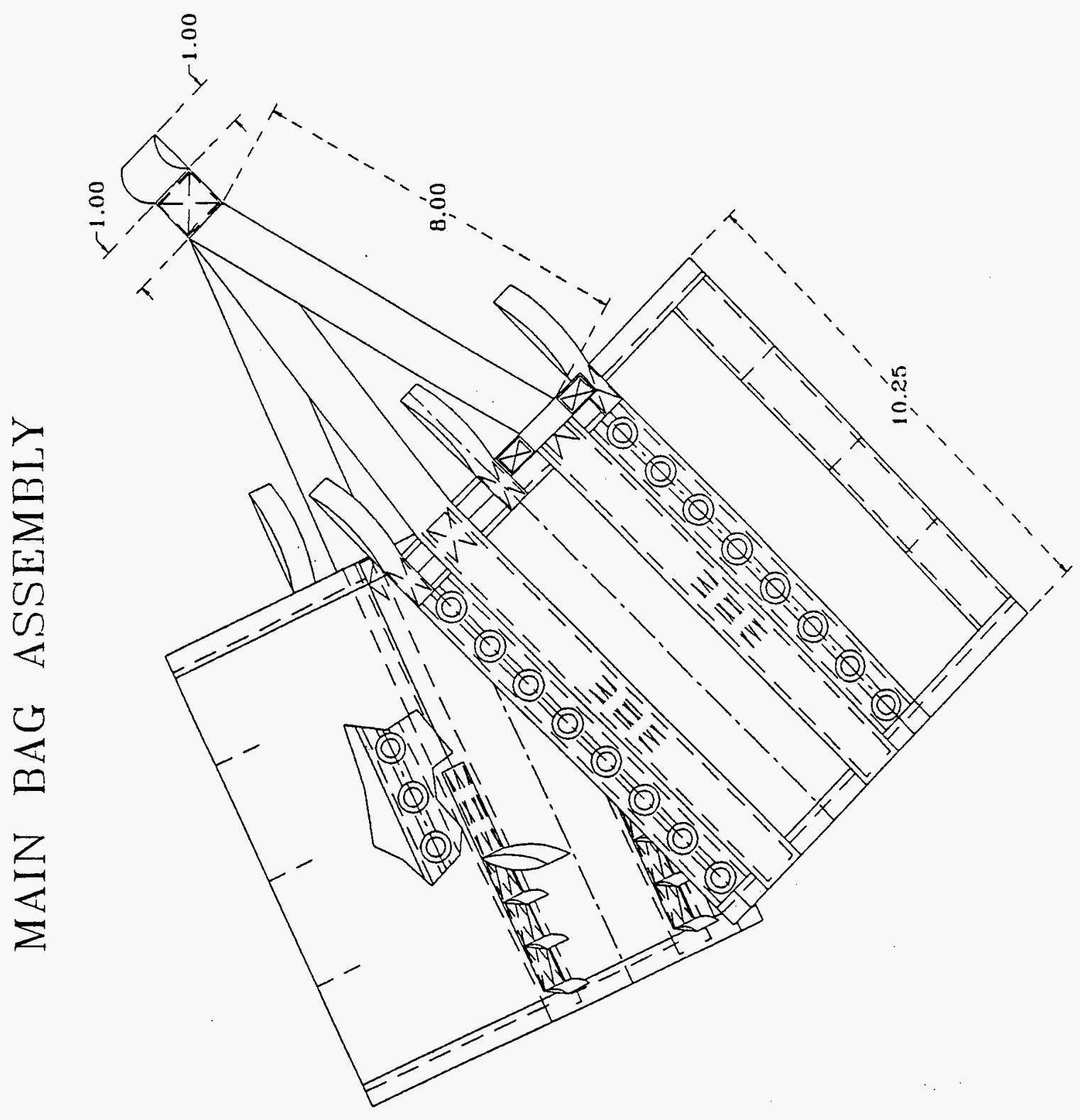



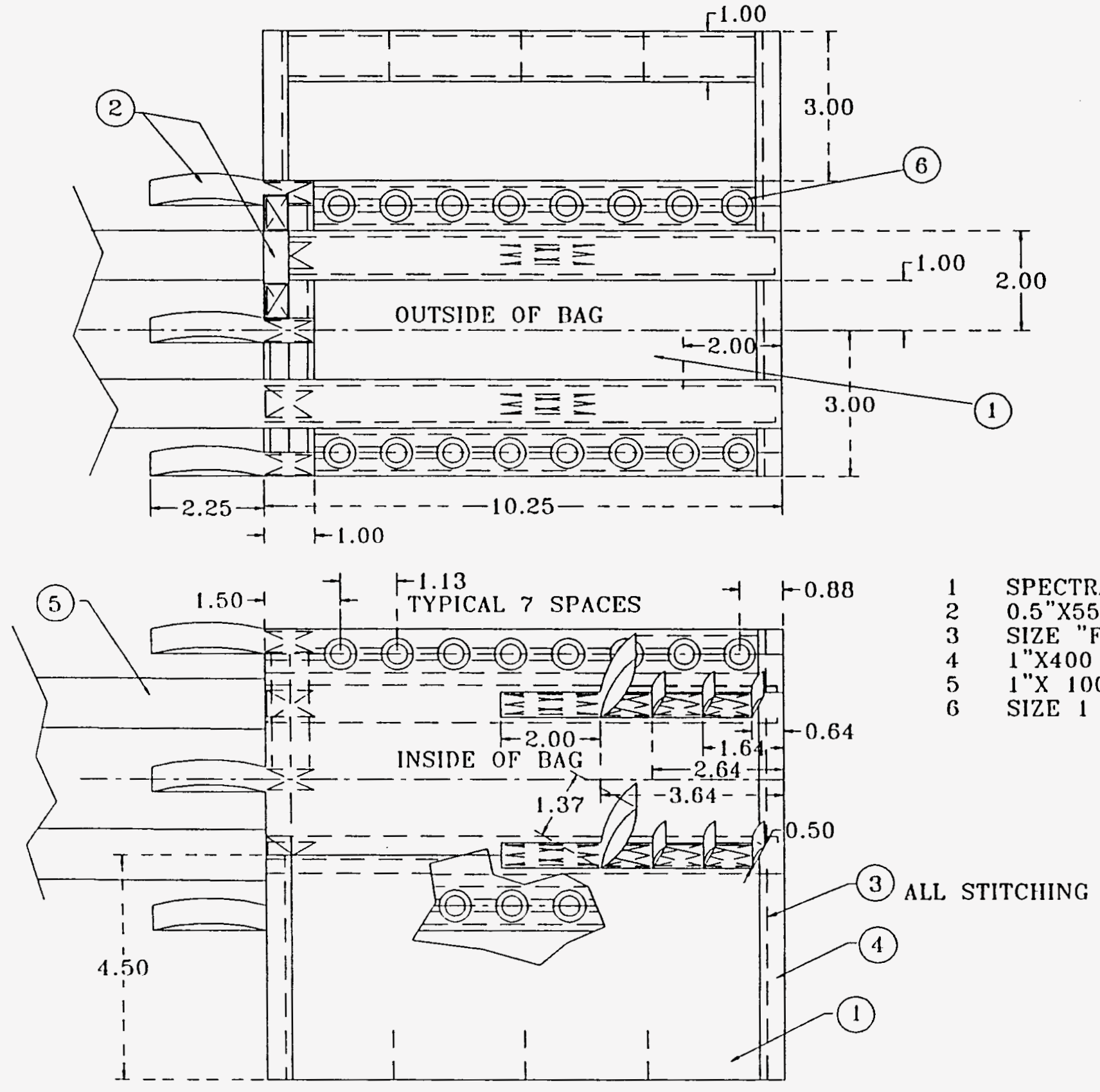


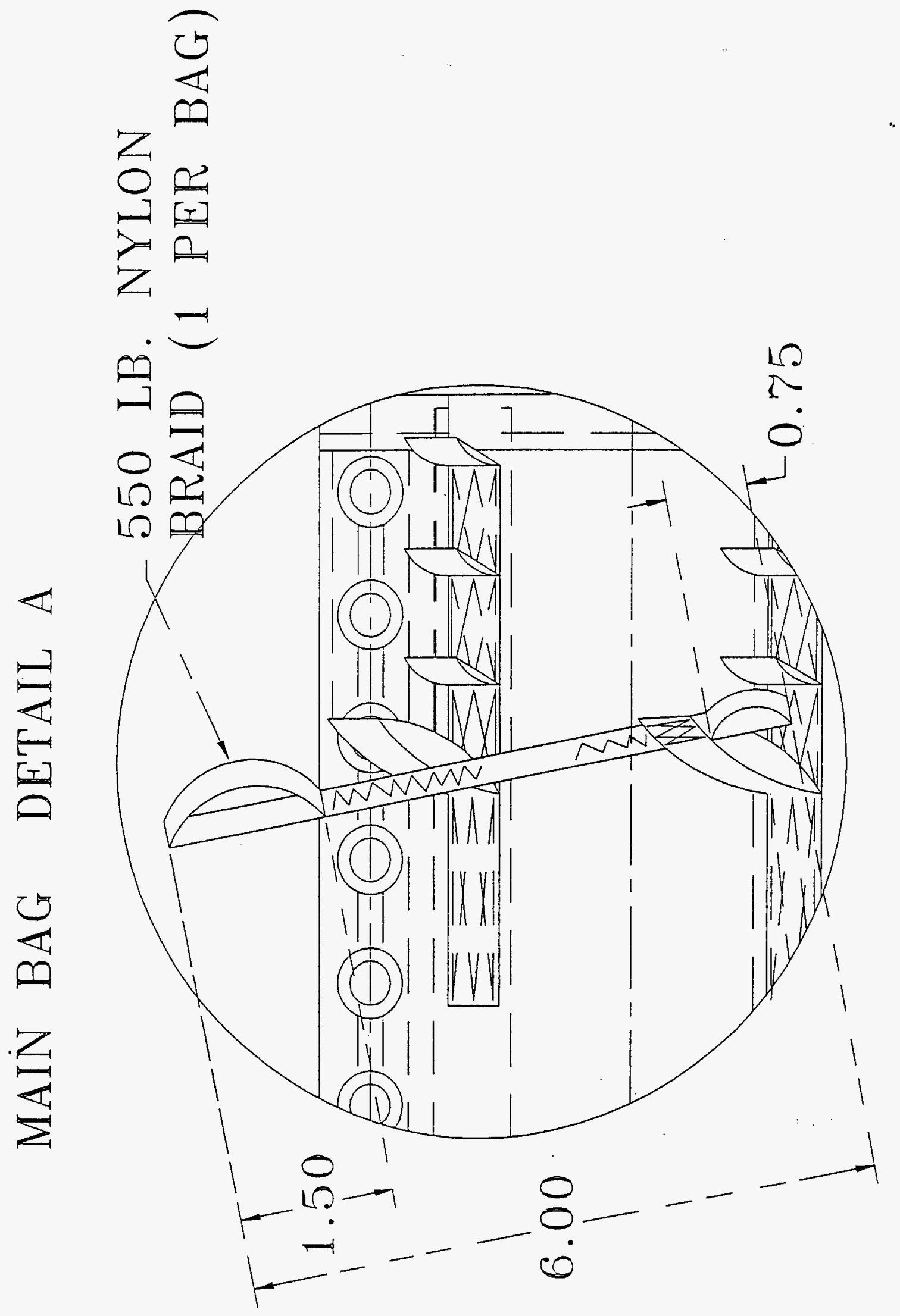




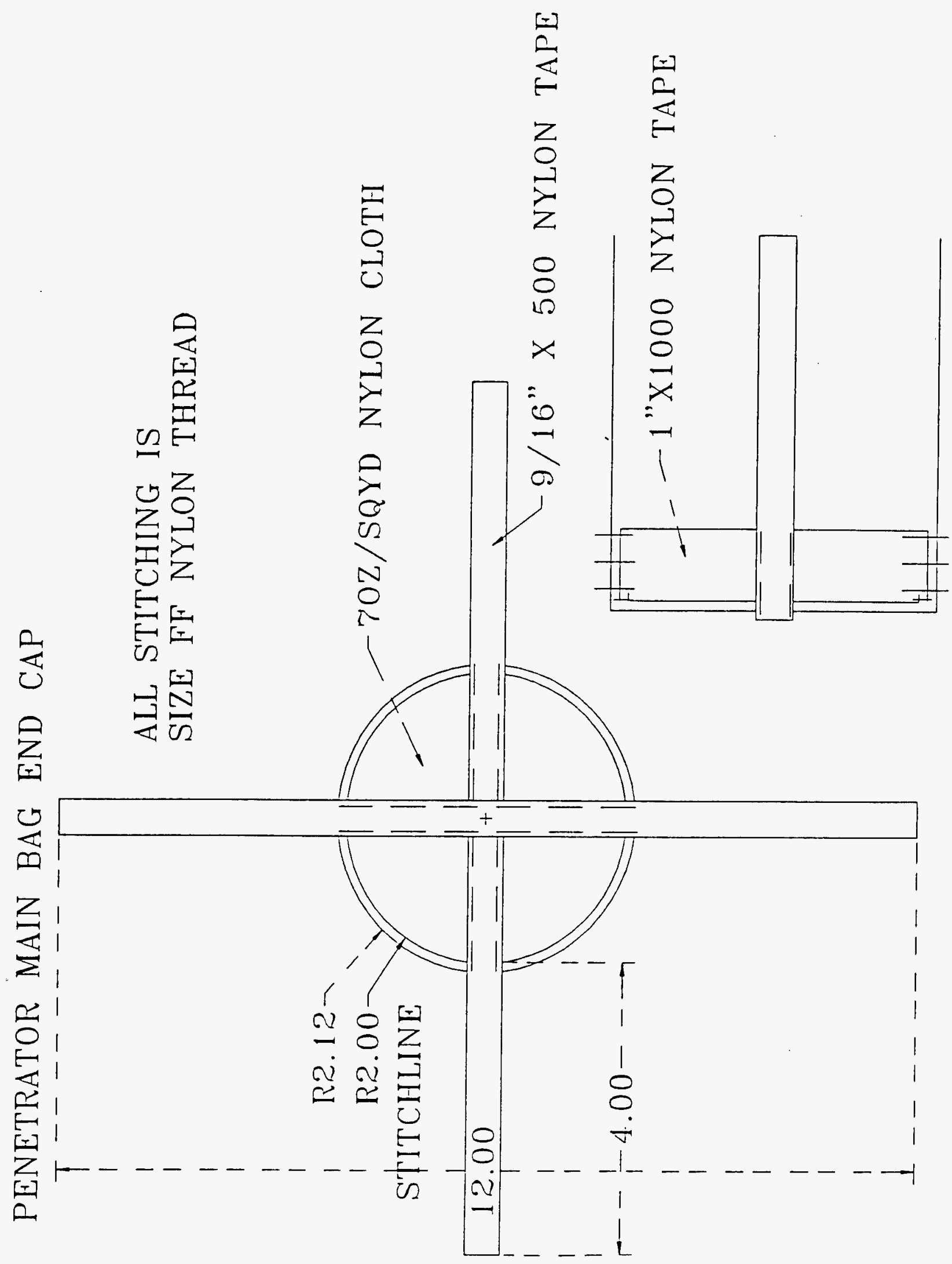




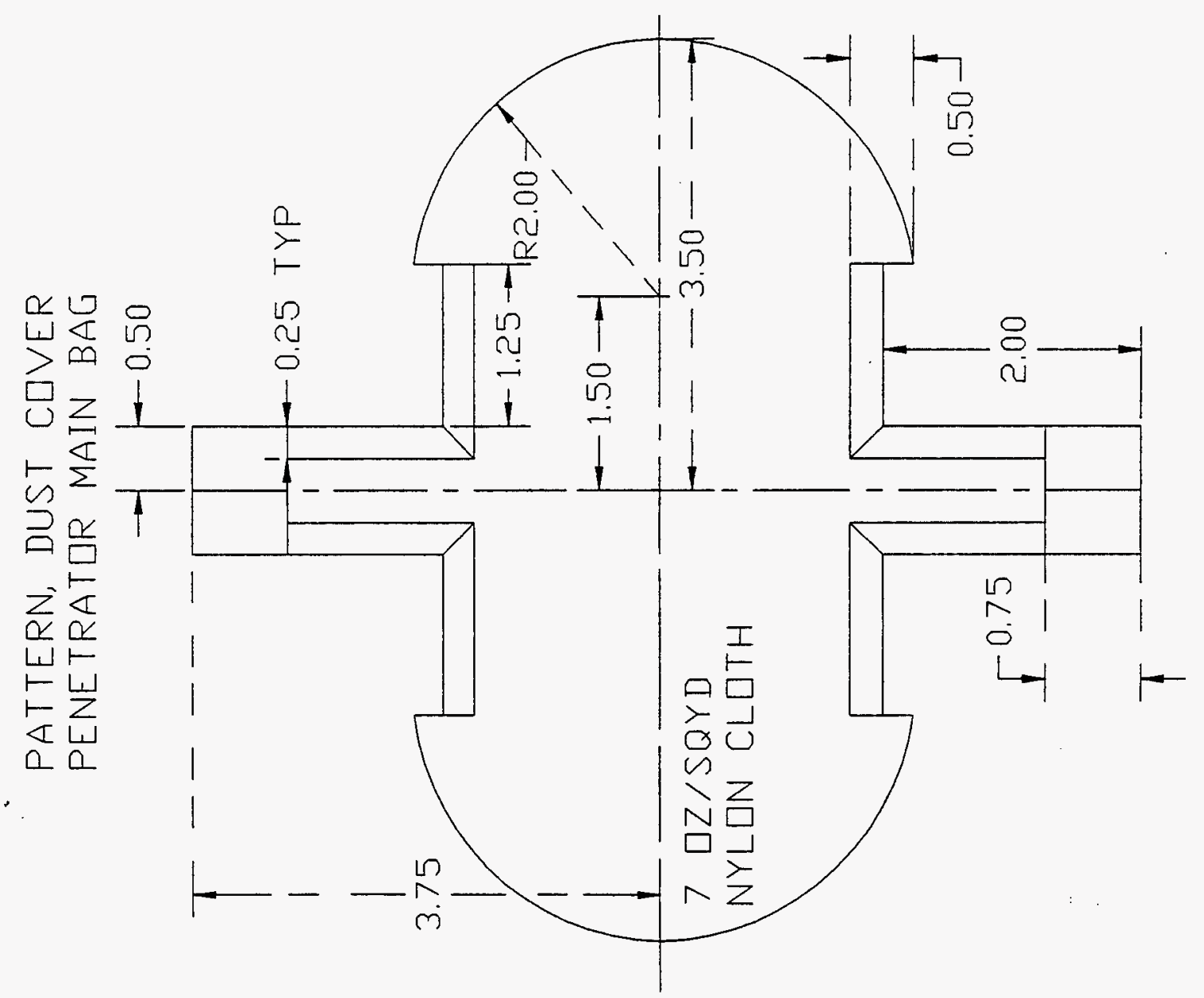



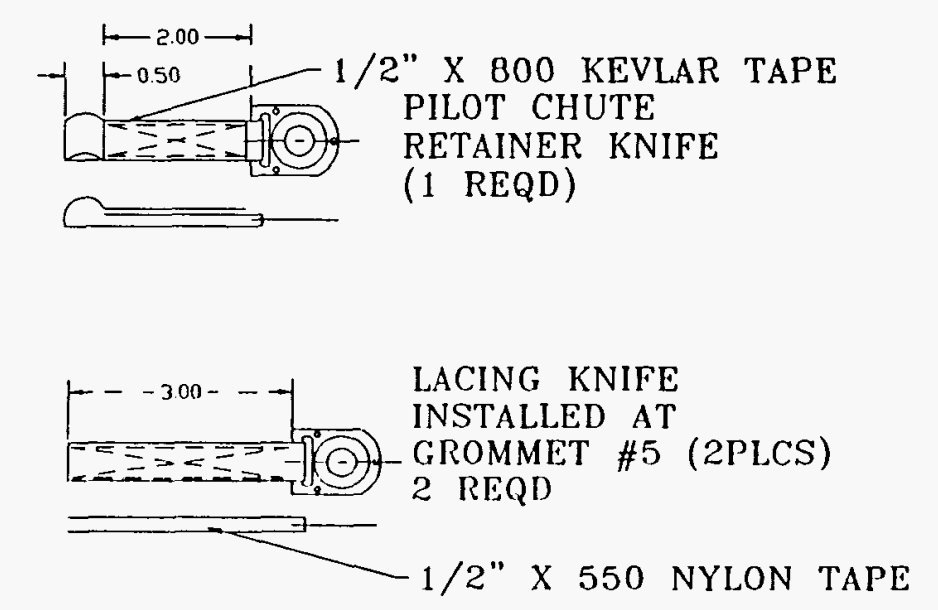

a

\section{KNIFE LANYARDS PENETRATOR CHUTE}

SEWN ON CANOPY

AT SKIRT ON RADIALS

10 AND 20

ALL KNIVES ARE

SMALL, EQUIVALENT

TO FORGECRAFT

$\mathrm{P} / \mathrm{N} 58$ B 6253

ALL STITCHING IS

SIZE "FF"

SEW NYLON WITH NYLON

AND KEVLAR WITH KEVLAR

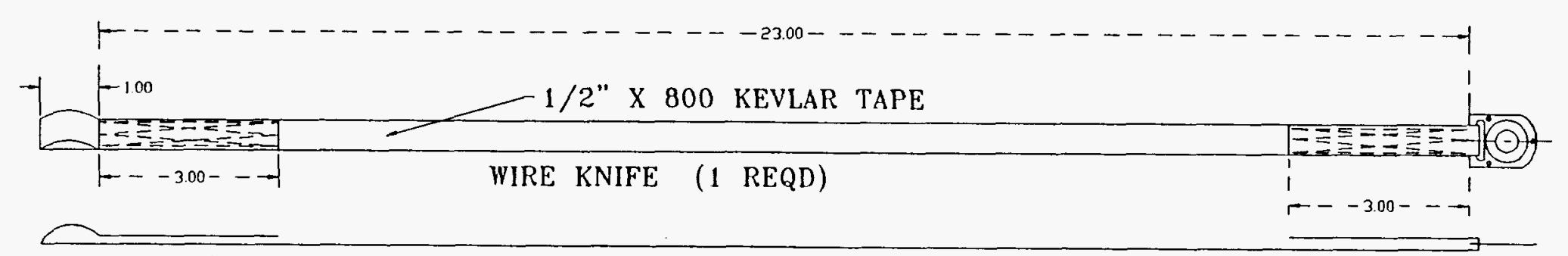


1.3-ft-dia Pilot Parachute Drawings 


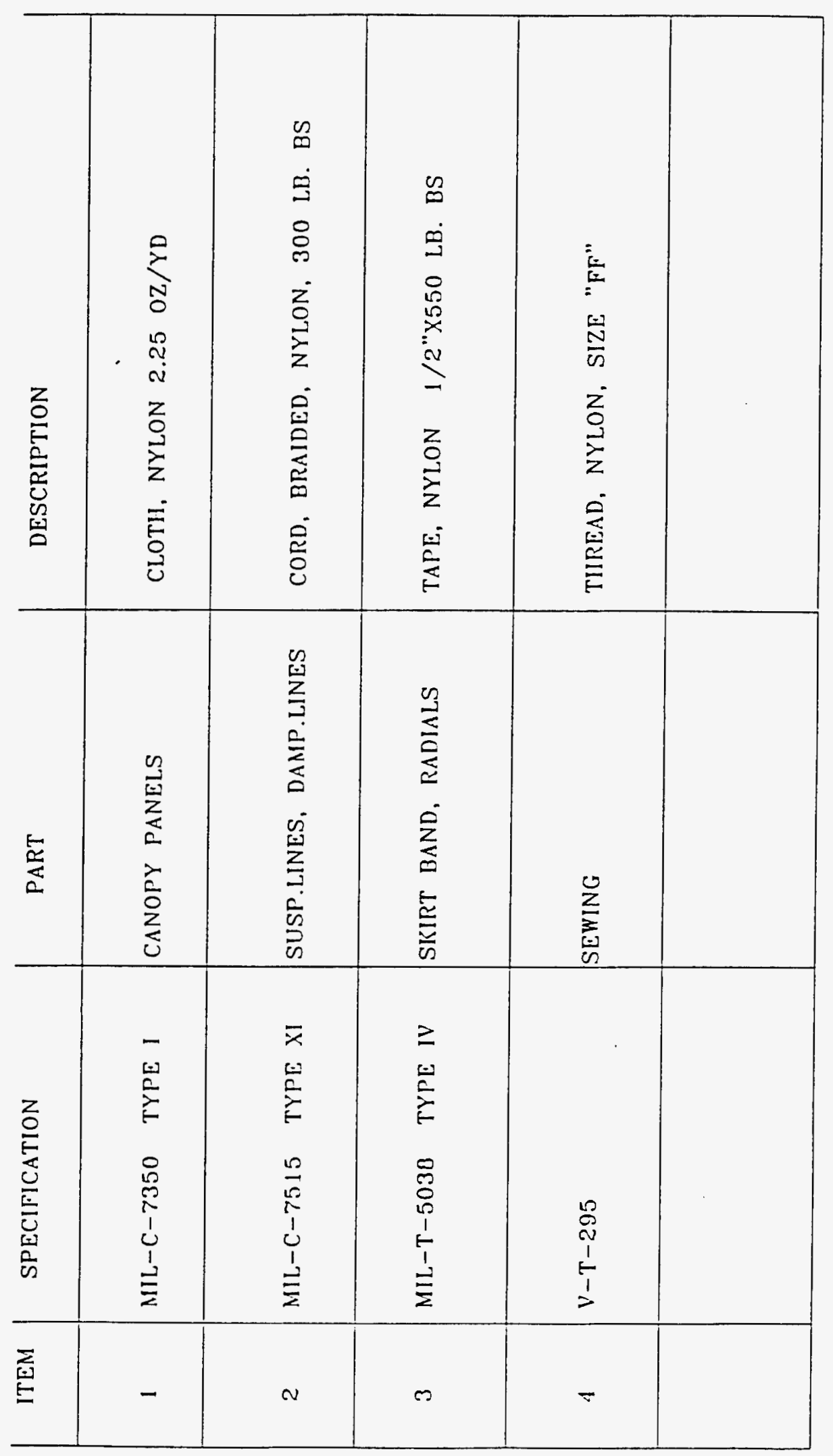




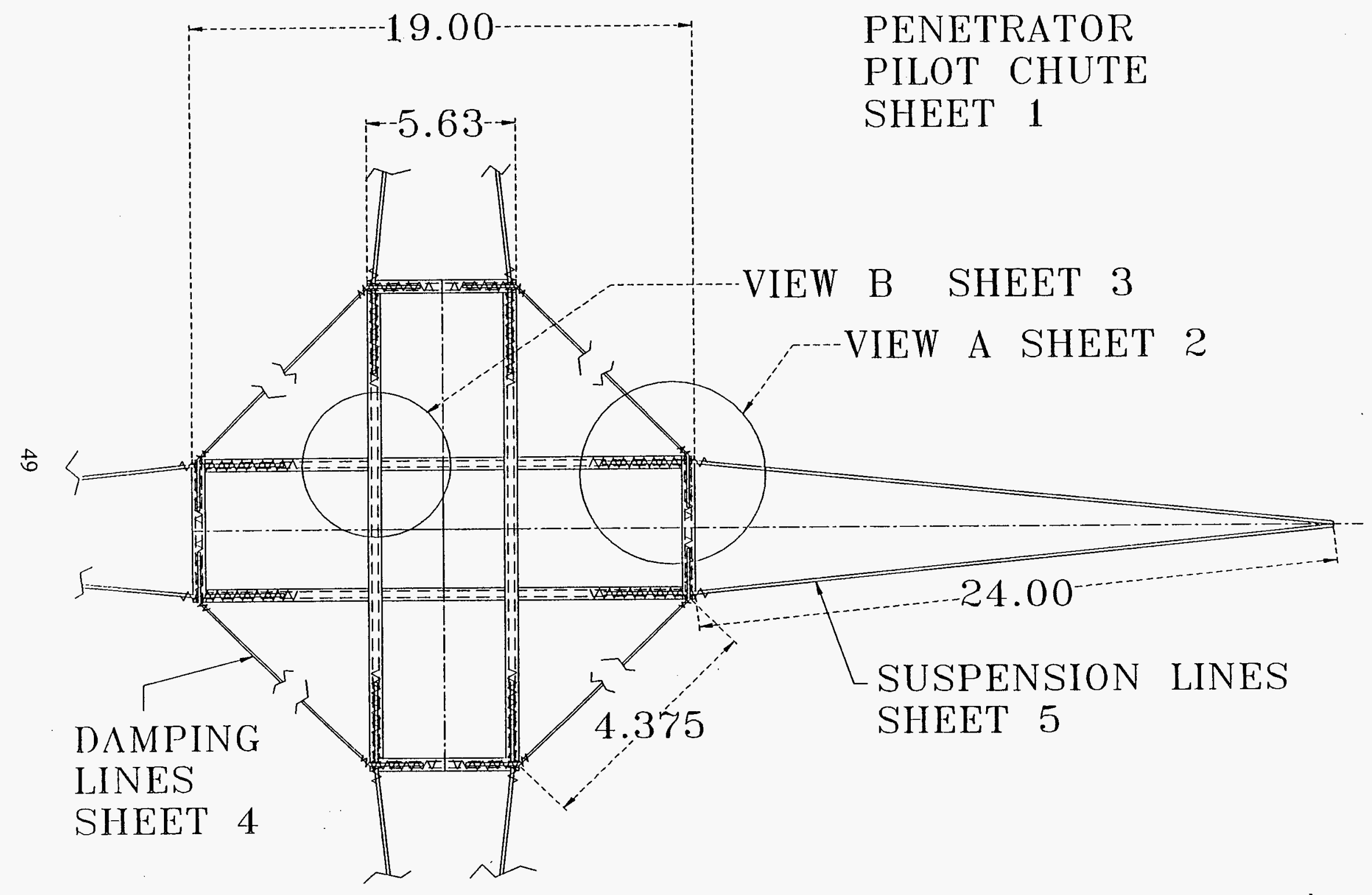

PENETRATOR PILOT CHUTE SHEET 1

VIEW B SHEET 3 -VIEW A SHEET 2 
PENETRATOR

PILOT CHUTE

SHEET 2

2 ROWS STRAIGHT LARRY WHINERY

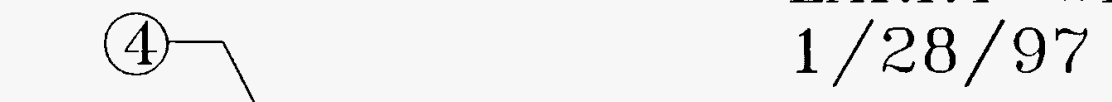

os

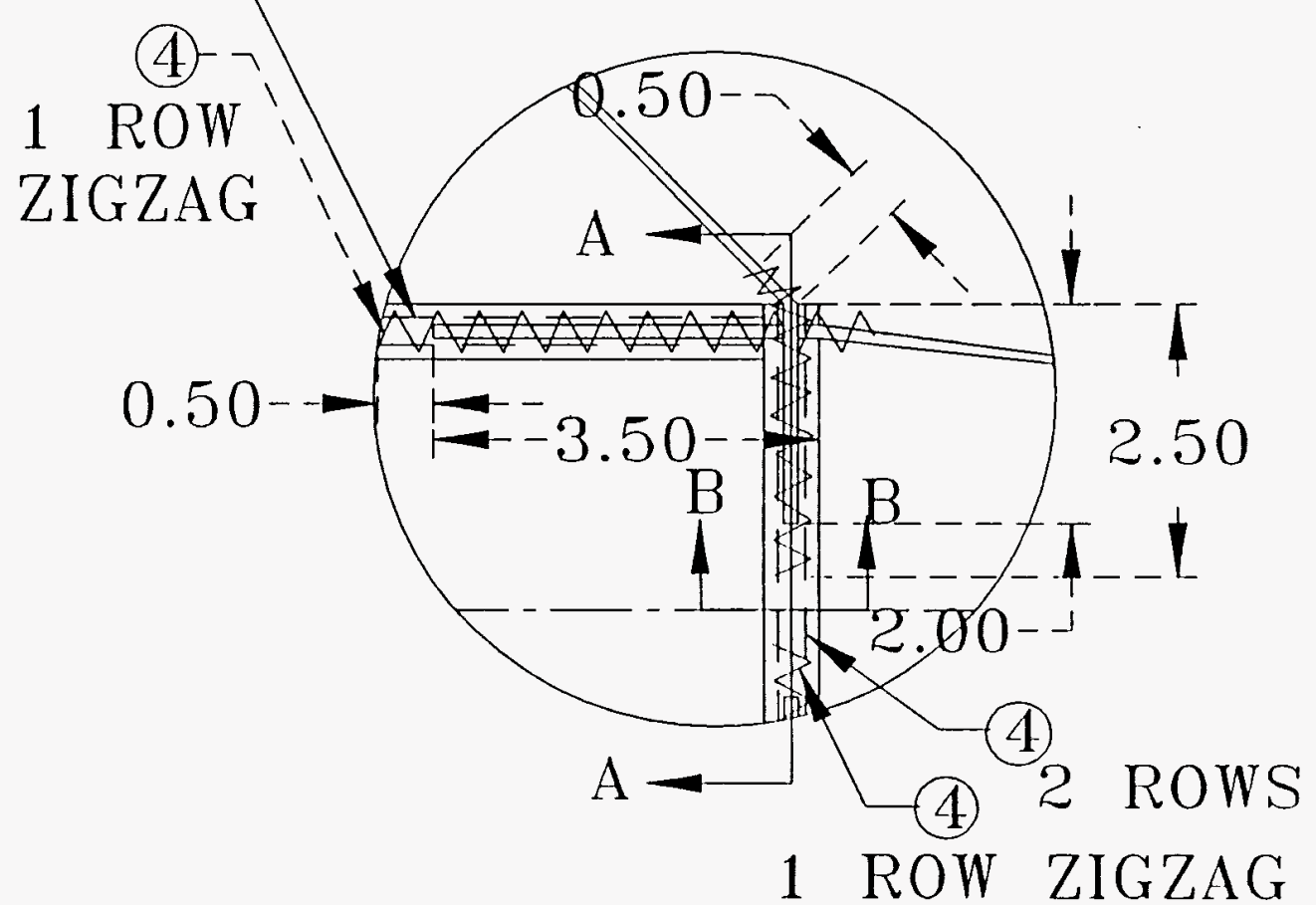

SECTION A-A

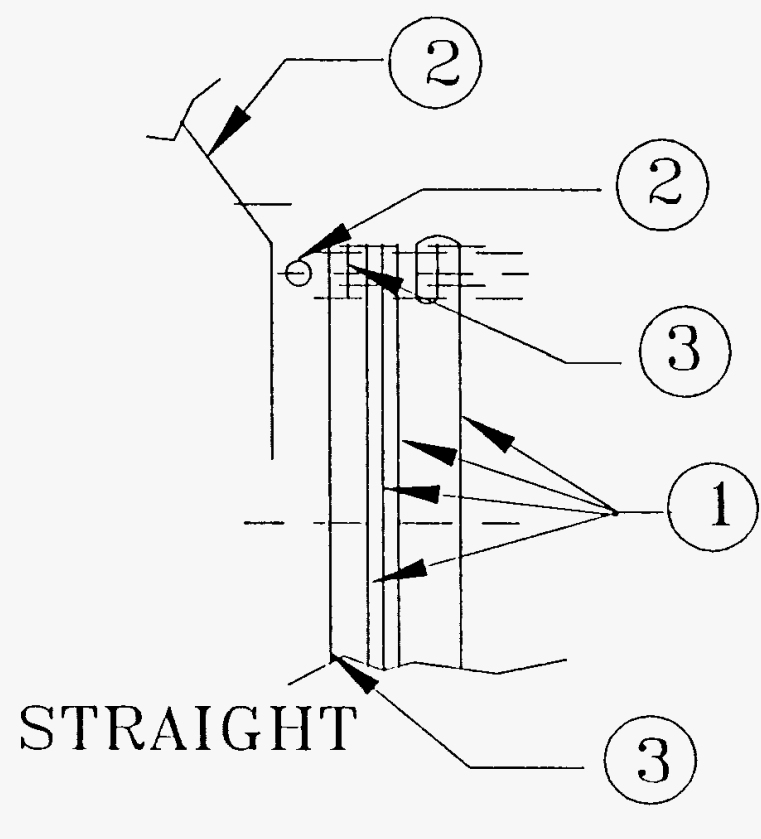

SECTION B-B

\# 


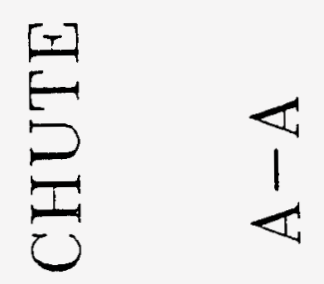

$\underbrace{}_{\infty}$

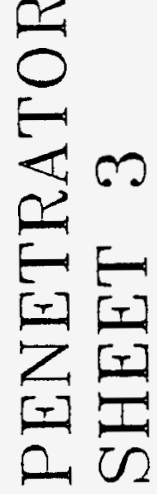

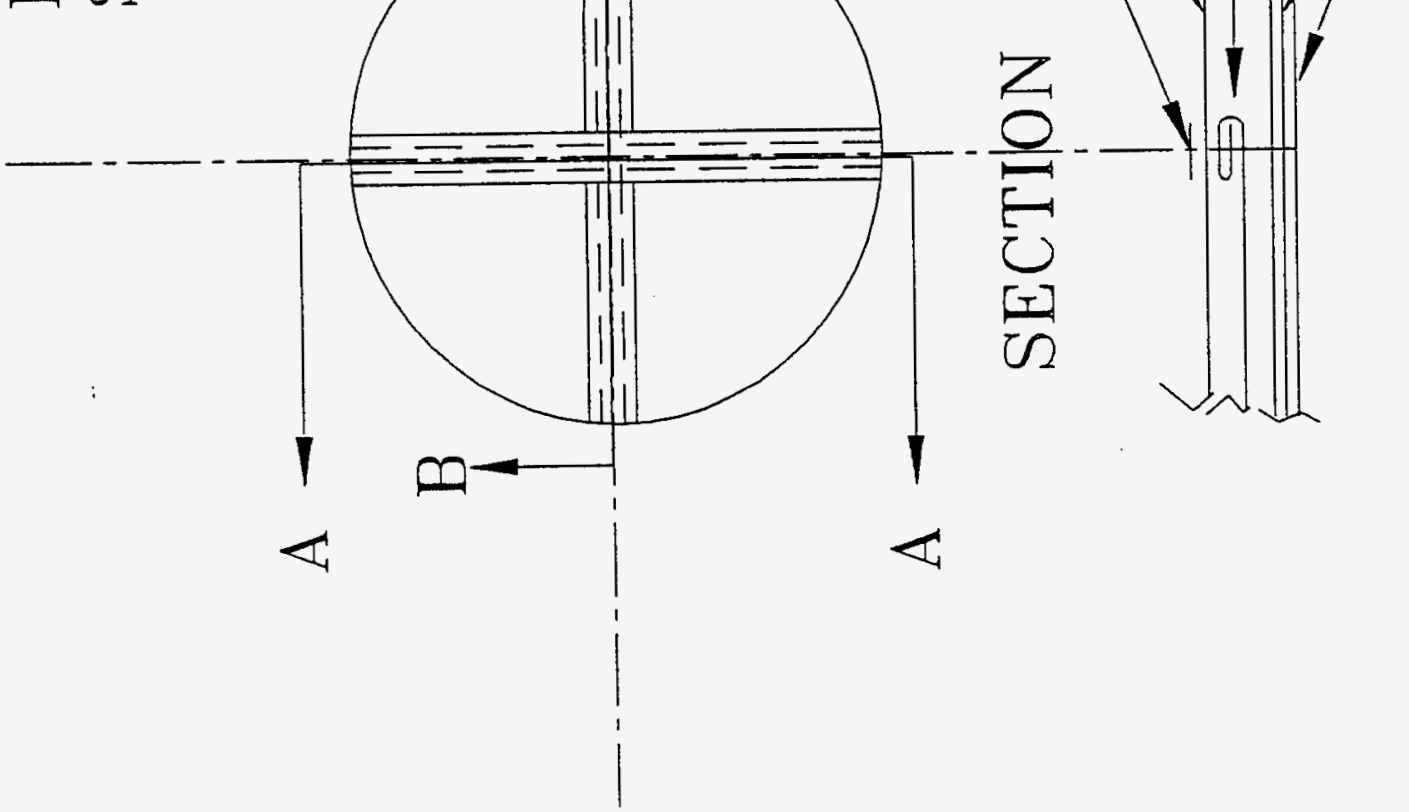




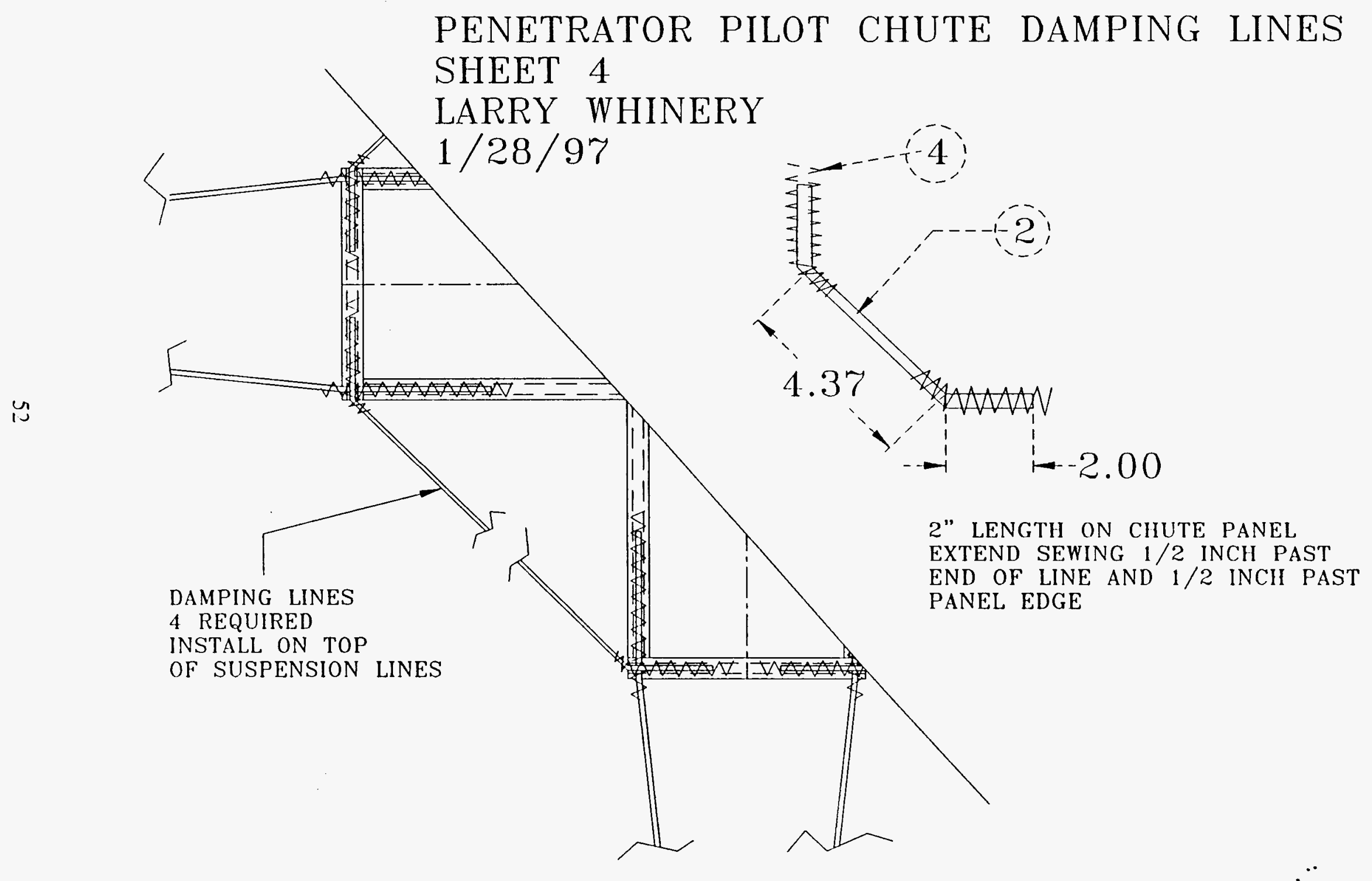


PENETRATOR PILOT CHUTE SHEET 5

LARRY WHINERY $1 / 28 / 97$

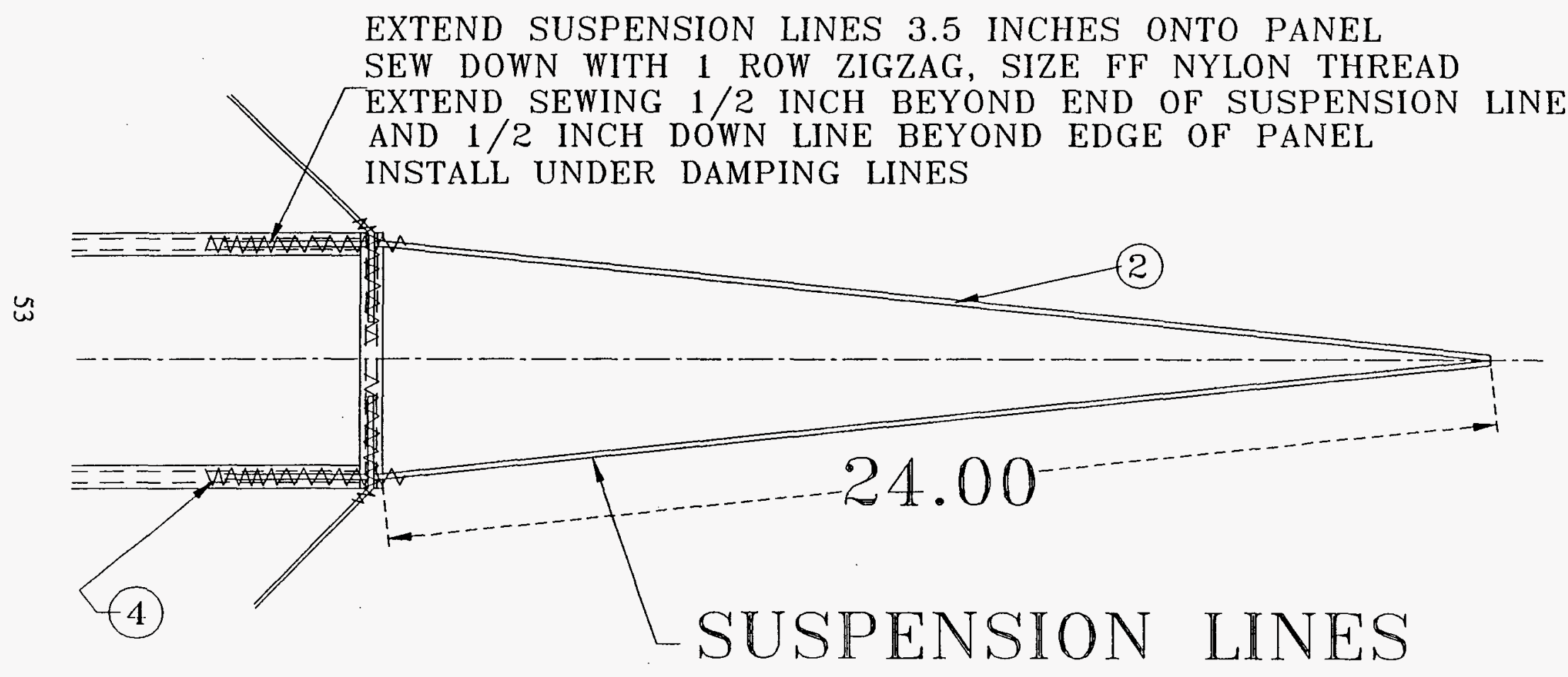

4 SETS OF SUSPENSION LINES WILL BE JOINED TOGETHER AT LOOP END BY SERVING ALL LINES TOGETHER TO FORM A 1" FLAT LOOP 


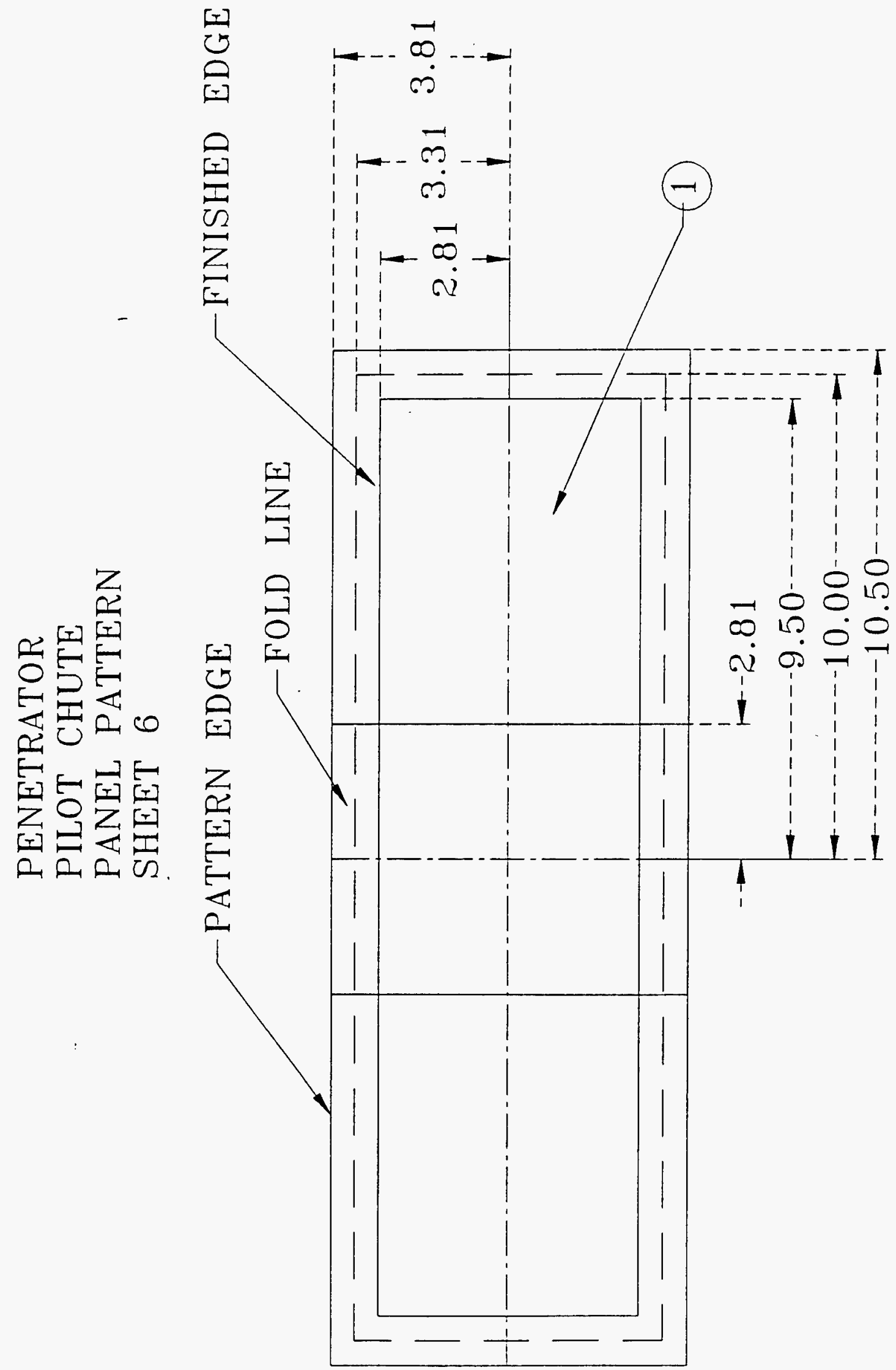




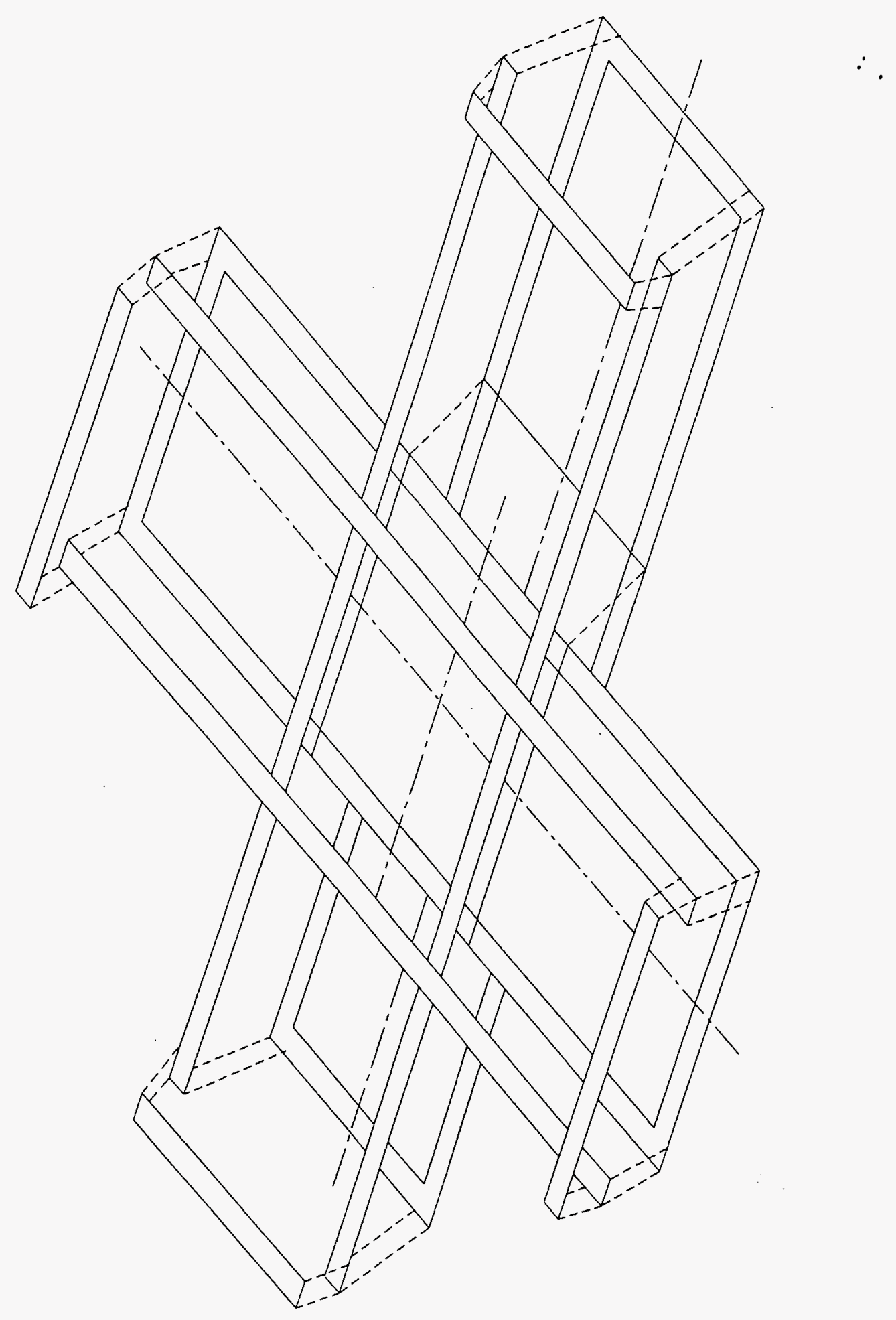


Telemetry Package Sling Drawings 


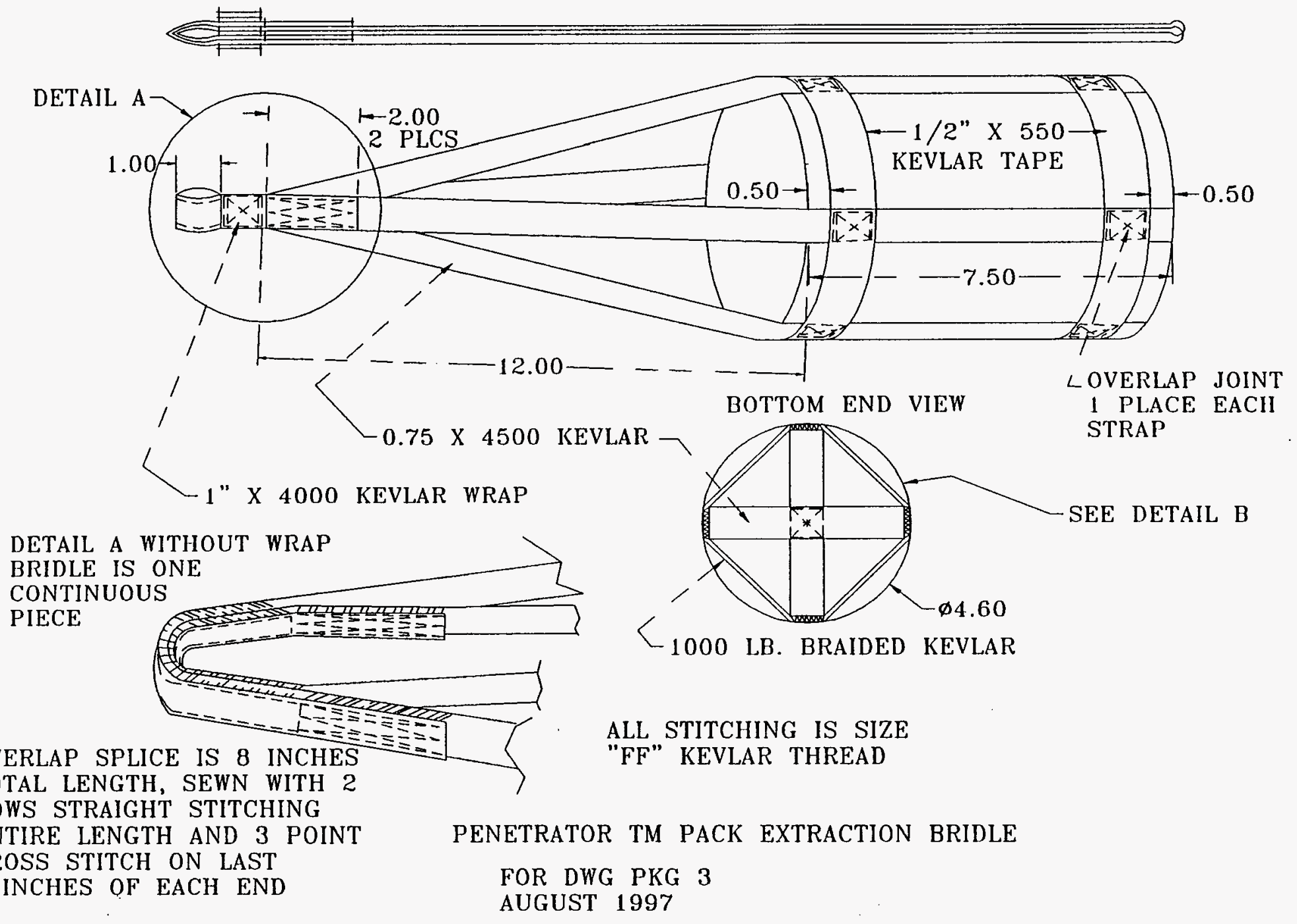




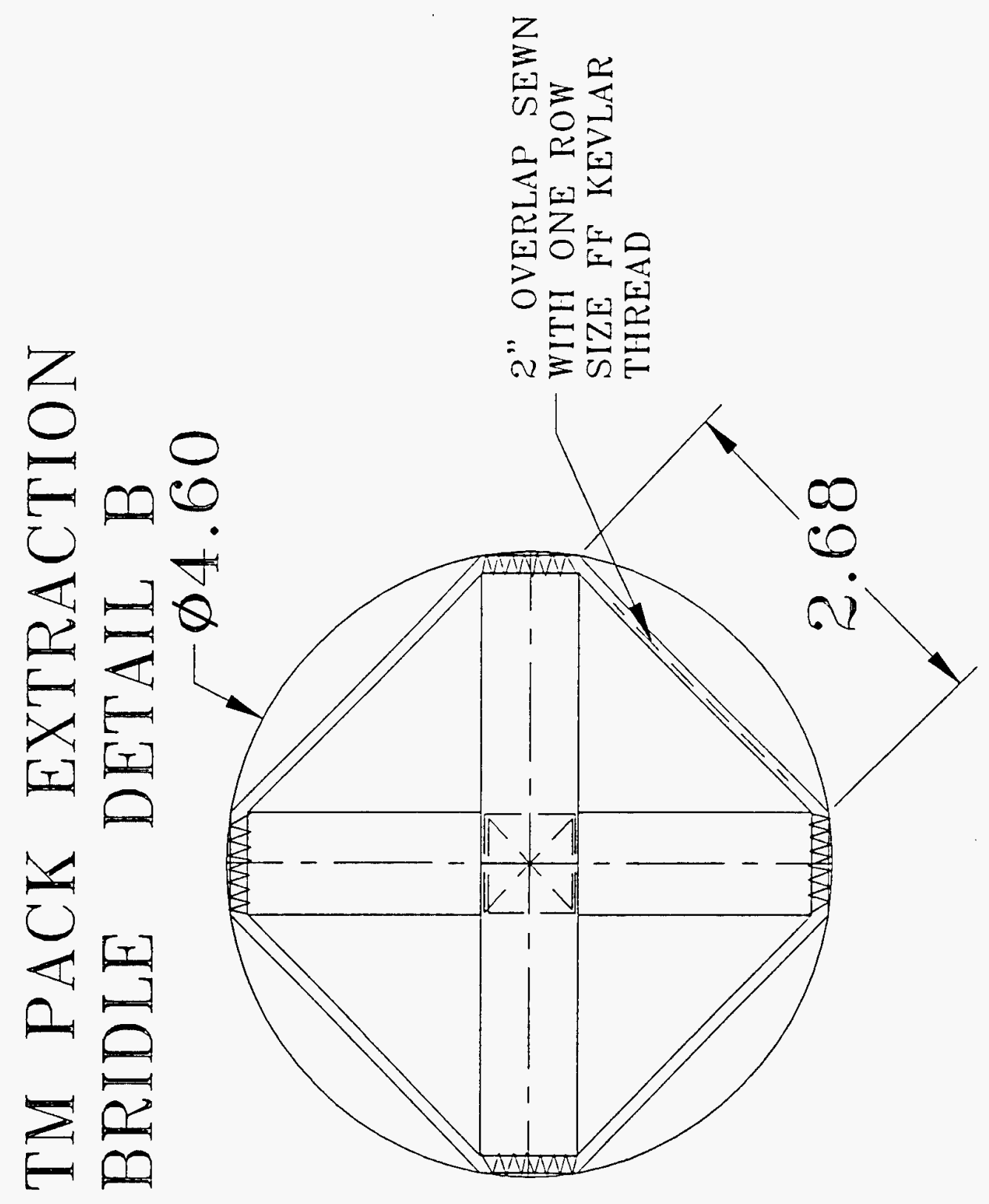




\section{Appendix B}

WBS Parachute System Packing Checklist

and

Draft WBS/Telemetry Package Integration and Installation Manual 
Parachute Serial Number Built to Drawing Package \#

Pack Number Date Packed Packed by Inspected by

Install packing plate to the closed end of the deployment bag using double 5 cord nylon thread, color red, through the holes provided

Lay out canopy on table and straighten lines

Attach vent break cord ( $100 \mathrm{lb}$ nylon cord) around vent lines and tie with a bowline knot and an overhand knot

Mark the vent line at 18" from the knot around vent lines

Attach vent break cord to the loop at the closed end of deployment bag at the $18^{\prime \prime}$ mark and tie with a bowline knot and an overhand knot

Install temporary lacing on the deployment bag

Install the deployment bag into the packing fixture can

Install temporary line ties around the lines at 12" spacing starting at the skirt. Use YELLOW $90 \mathrm{lb}$. tape -12

ties, tied with a bow knot

Fold the canopy to a width of approximately $8^{\prime \prime}$

Stow the canopy into the bag by accordian folding until the skirt band is below the canopy retainer loops of the bag.

Pull the two lacing knives installed on radials $\# 10$ and $\# 20$ to the outside

Thread the free end of the retainer loop through the canopy retainer loops, around the suspension lines and through the other loop of the retainer

Pull a byte of suspension lines through the canopy retainer loop

Starting with the first temporary line tie, fold the suspension lines over and tie to one of the lowest bag ties of either bag panel using Ticket \# cotton cord.

NOTE: Make the tie by passing the cord through the bag loop, completely around the byte of suspension lines, and then tying the two free ends with a surgeon's knot and an overhand knot.

Make the second line tie in the same manner using one of the lowest bag loops of the opposite bag panel. Continue tying lines to the lowest available bag loops, alternating bag panels on each tie. After all line ties are made (12) remove all 12 temporary line ties Verify that all 12 temporary ties are removed

Tack the suspension line group loop to the inside of the bag so that the end of the loop is even with the end of the bag panel using 1 turn of single size 5 nylon cord, color red, with the knot on the outside of the bag.

\begin{tabular}{|l|l|l|}
\multicolumn{2}{|l|}{ Rigger Inspector } \\
& & \\
\hline 12 & & \\
\hline & & \\
\hline & & \\
\hline & & \\
\hline & & \\
\hline & & \\
\hline & & \\
\hline
\end{tabular}




\begin{tabular}{|l|l|}
\hline $\begin{array}{l}\text { Install the dust cover to the open end of the deployment bag using one turn of single size "E" nylon thread } \\
8 \text { places. }\end{array}$ & \\
\hline Work the dust cover pocket down into the pack by pushing the suspension lines to the side. & \\
\hline $\begin{array}{l}\text { Install the End plate into the dust cover slot and tack to the bag panels using double size } 5 \text { nylon cord } \\
\text { through the holes provided. }\end{array}$ & \\
\hline $\begin{array}{l}\text { Install the lacing knives attached to the skirt band at radials \#10 and \#20 to the bag over grommet \#5 of each } \\
\text { bag panel on the side opposite the gusset. Tack in place with double Size } 5 \text { nylon cord, color red, with the } \\
\text { knot on the outside of the bag. }\end{array}$ & \\
\hline $\begin{array}{l}\text { Tack the knives again using single size } 5 \text { Nylon cord through the hole at the end of the knife blade. Put the } \\
\text { knot on the outside of the bag. }\end{array}$ & \\
\hline Install the lacing knives on grommet number 2 of each bag panel in the same manner as above. & \\
\hline $\begin{array}{l}\text { Thread the lanyard end of the lacing knives at grommet number } 2 \text { between the bag panel and the end } \\
\text { packing plate. }\end{array}$ & \\
\hline Remove the temporary lacing from the bag panels & \\
\hline Lace each side of the pack using 300 lb. braided nylon. (Double laced) & \\
\hline $\begin{array}{l}\text { Pull the parachute down to a circumference less than 14" } \\
\text { Single the lacing on both sides of the pack and tie off each end using two half hitches and an overhand } \\
\text { knot. }\end{array}$ & \\
\hline Cut out the temporary tacks on the lacing knives and the temporary tack on the suspension line group loop & \\
\hline $\begin{array}{l}\text { Attach the free end of the pilot chute line cord (2000 lb braided nylon) to the deployment bag bridle loop. } \\
\text { Pass the line through the loop and secure using a Chinese Finger, } 4 \text { inches long. Place the mark of the line } \\
\text { at the bag loop. }\end{array}$ & \\
\hline Sew the Chinese finger with one row of straight stitching, size "FF" nylon thread. & \\
\hline $\begin{array}{l}\text { Fold the line under the pilot chute and center the pilot chute over the closed end of the main deployment } \\
\text { bag. }\end{array}$ & \\
\hline $\begin{array}{l}\text { Run a length of size } 5 \text { nylon cord through } 3 \text { adjacent pilot chute retainer loops, through the pilot chute } \\
\text { retainer knife, and through the other } 3 \text { retainer loops and tie using a square knot with overhand knot. }\end{array}$ & \\
\hline Safety the retainer knife to the bag using single size "E" nylon thread, 2 places. & \\
\hline
\end{tabular}




\section{WBS Parachute Installation Procedure}

Figure 1 shows the TM pack with antenna and ribbon wire, the TM bridle and the main parachute pack. (See Figure 1)

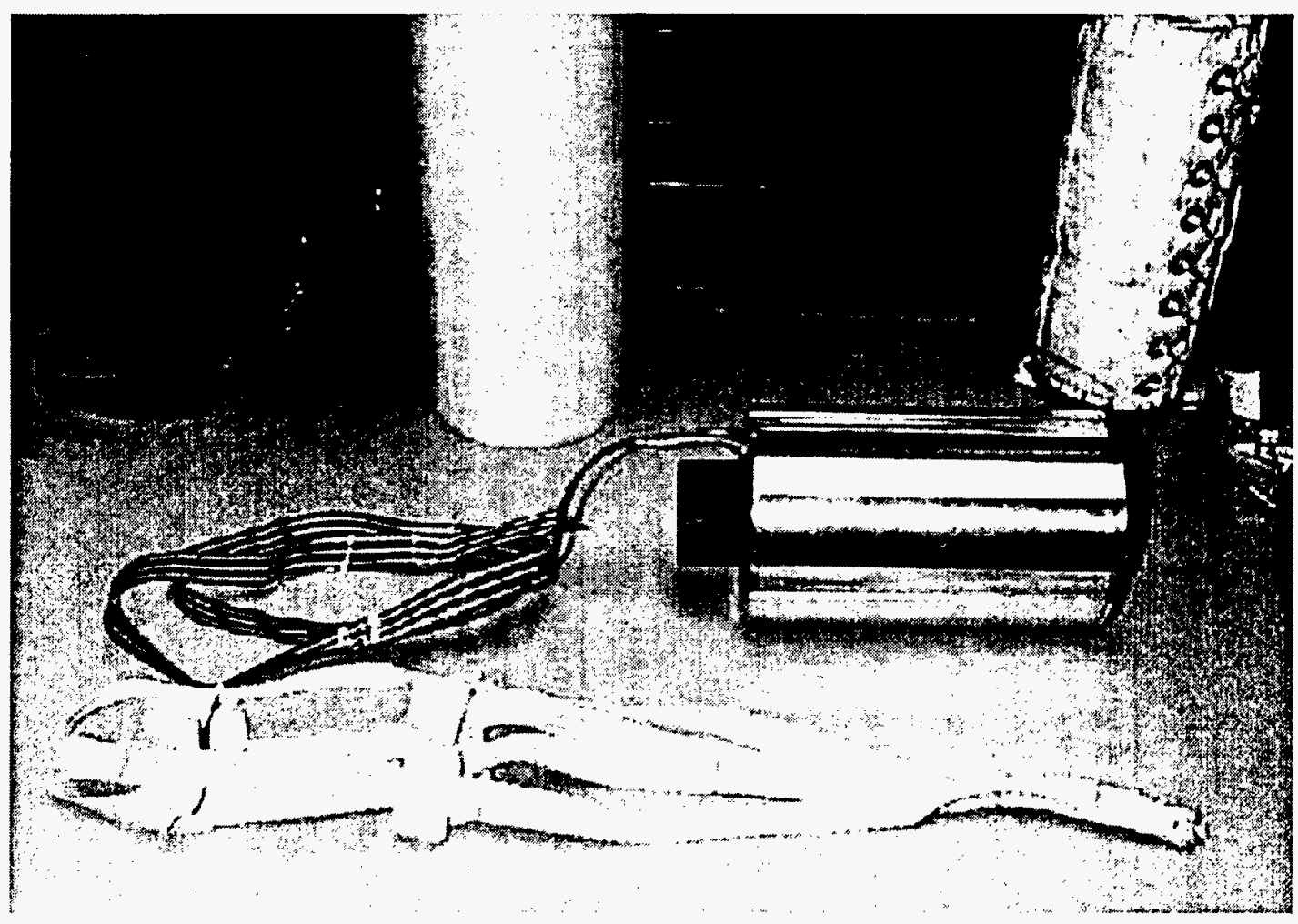

Figure 1 
1. Install TM bridle around TM Pack so that the antenna of the TM pack faces the end loop of the bridle and the crossover webbing of the bridle is against the flat bottom of the TM pack.

2. Ensure that the legs of the TM Bridle fit into the slots of the TM Pack and the edges of the retention bands (2 each) lay flat with no turn backs. (See Figure 2.) Align the TM Bridle so that the outer, non-spliced leg of the bridle is at the location where the ribbon wire exits the TM pack.

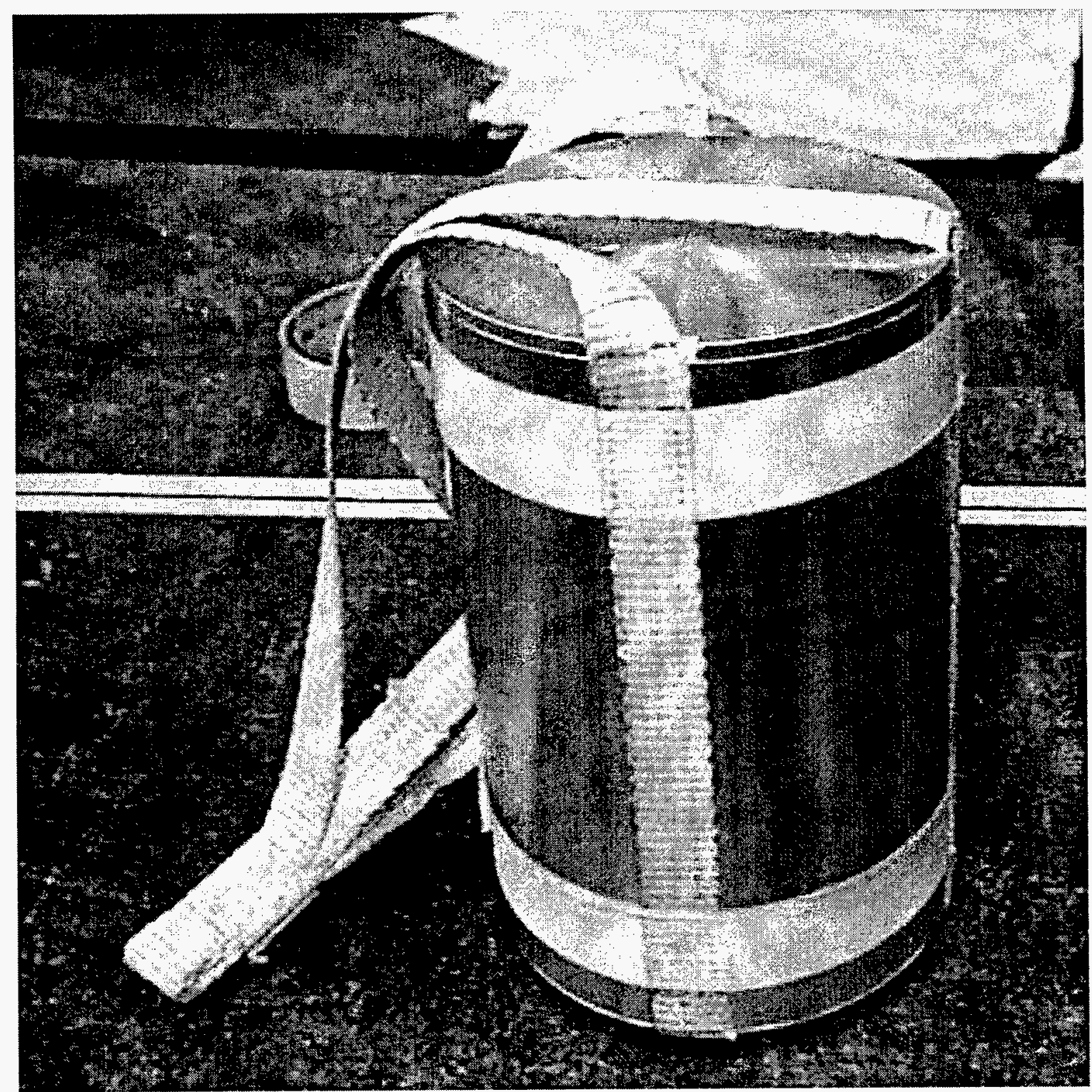

Figure 2 
3. Keeping the ribbon wire straight, route the wire around to the outside of the nearest bridle leg. Hand tack the wire to the bridle leg in three places: one near the TM Pack, one in the middle of the bridle leg and one near the confluence point of the TM bridle, using one turn of waxed Size 5 nylon cord. Tack through the bridle leg and tie around the ribbon wire. Do not tack through the ribbon wire. (See Figure 3)

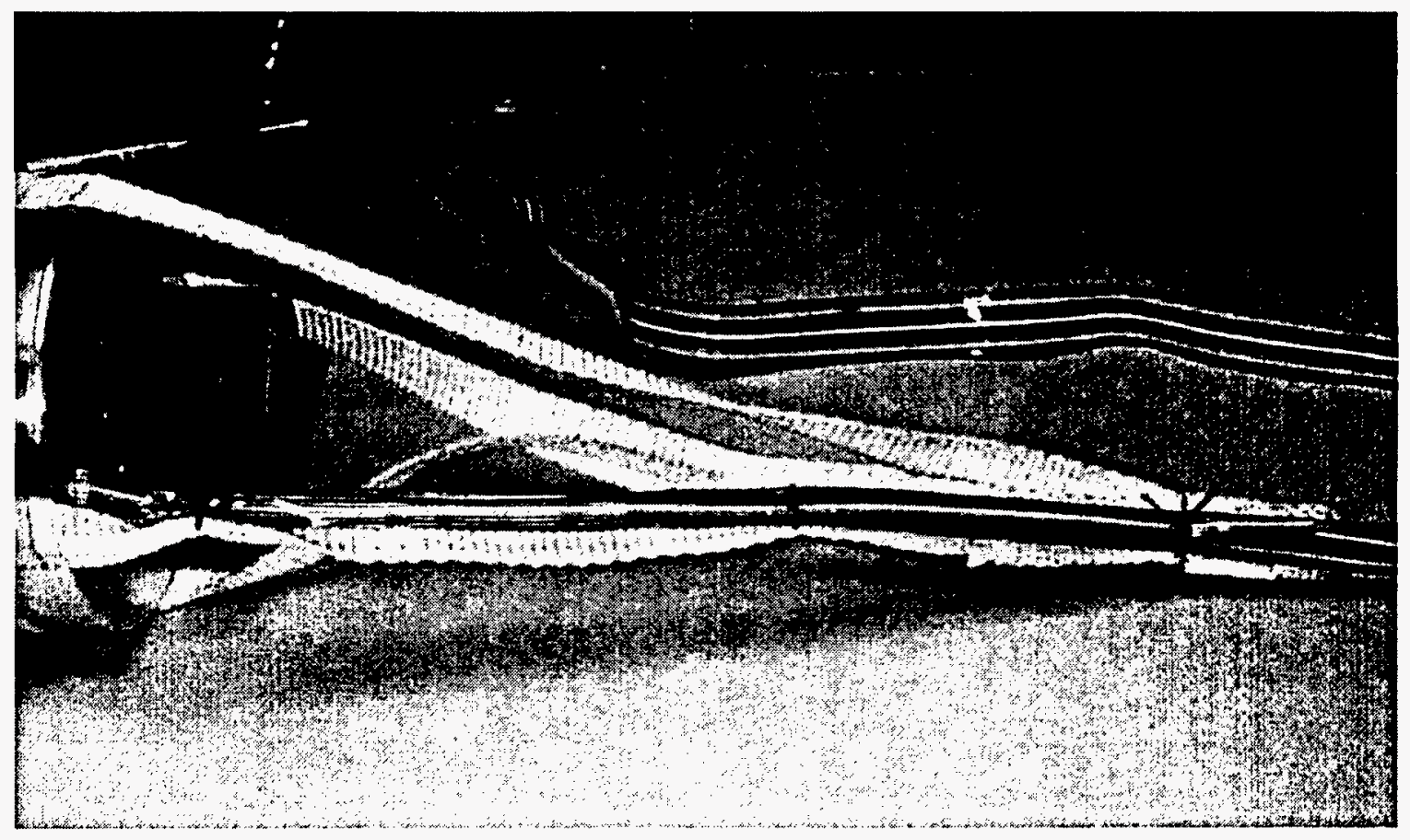

Figure 3

4. Remove the packing plate from the suspension line end of the main parachute pack. 
5. Attach the loop of the TM bridle to the main parachute suspension line loop by performing the following steps:

a. Cut an approximately 2 -foot length of $4000 \mathrm{lb}$. breaking strength Kevlar braid.

b. Pass the Kevlar braid through one of the main parachute lacing knife lanyards, then through the suspension line loop and then through the second lacing knife lanyard.

c. Bring the loop of the TM bridle up to the main parachute suspension line loop.

d. Pass each end of the Kevlar braid through the loop of the TM bridle from opposite directions.

e. Bring the two ends of the Kevlar braid together and tie using a square knot with an overhand knot on each free end.

f. Secure the two overhand knots by using one turn of waxed Size 5 nylon thread through both knots and tied using a square knot with an overhand knot on the free ends. (See Figure 4)

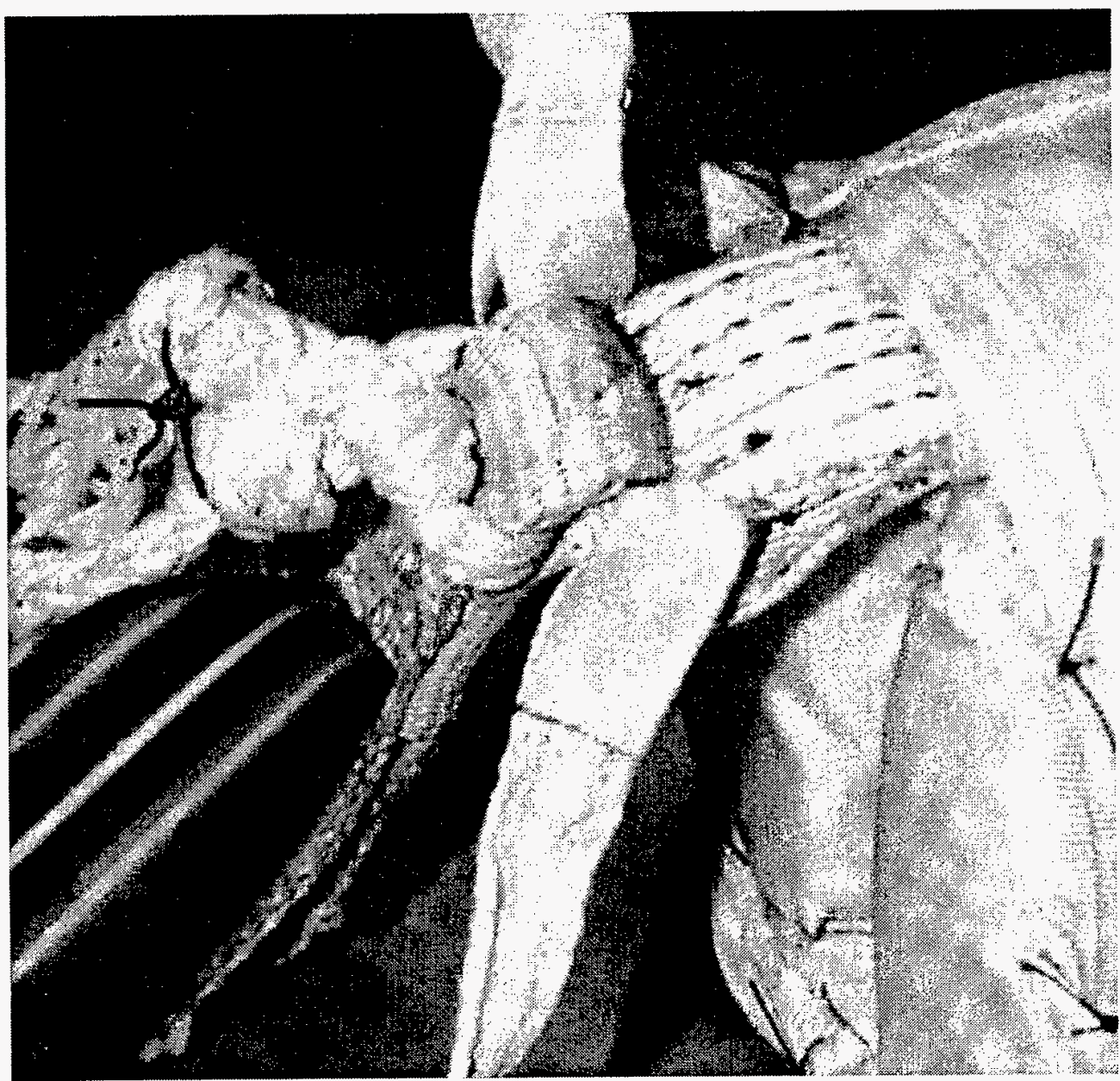

Figure 4 
6. Insert the ribbon wire through the loop on the main parachute bag. Orient the wire with the blue wire on the left and the brown wire on the right when viewing the parachute in an upright position. (See Figure 5)

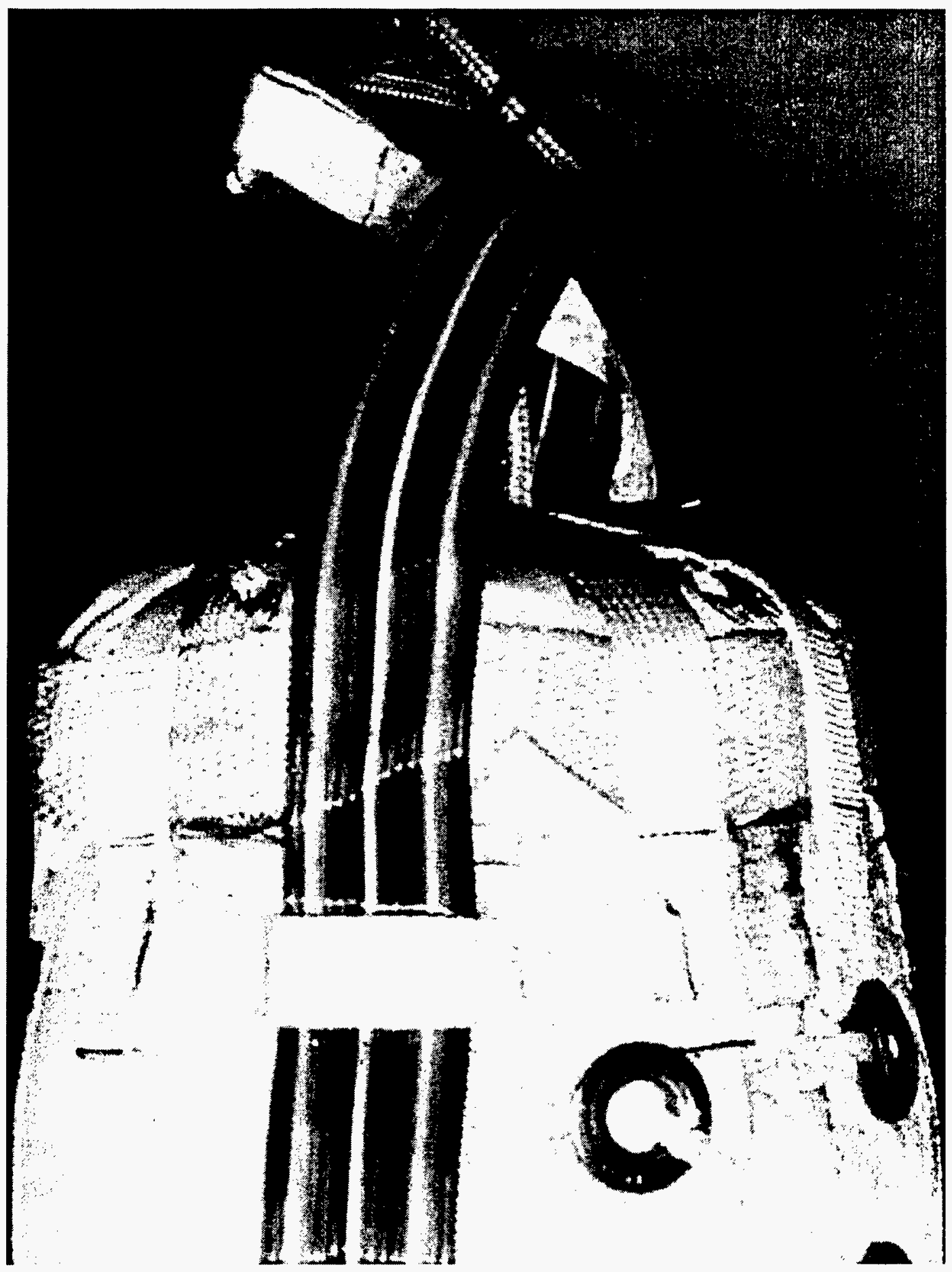

Figure 5 
7. Attach the ribbon wire to the main parachute pack in two places using waxed Size 5 cord nylon thread. Make one attachment at the bottom of the pack (suspension line end) and the other attachment at the middle of the pack. Tack through the edges of the reinforcement webbing and then tie around the ribbon wire. Ensure that the tacks do not penetrate the main bag and the parachute within the pack. (See Figure 6)

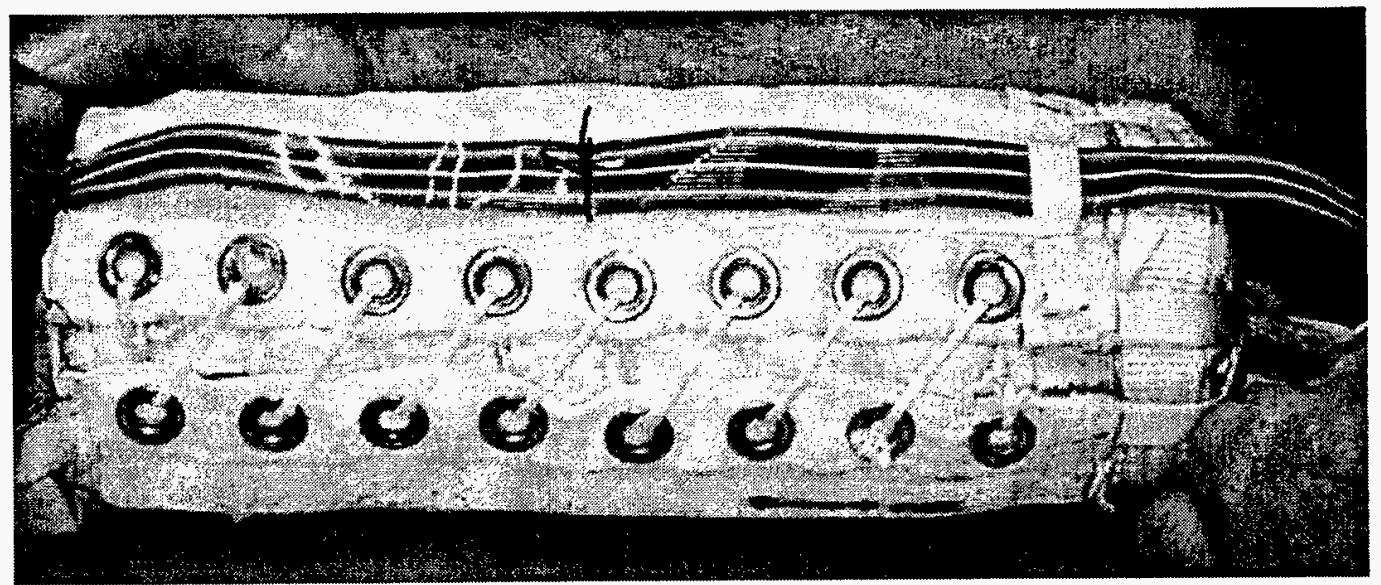

Figure 6

8. Fold the legs of the TM bridle as evenly as possible around the antenna of the TM pack. Move the TM pack against the parachute pack, inserting the antenna into the slot at the bottom of the parachute. (See Figure 7)

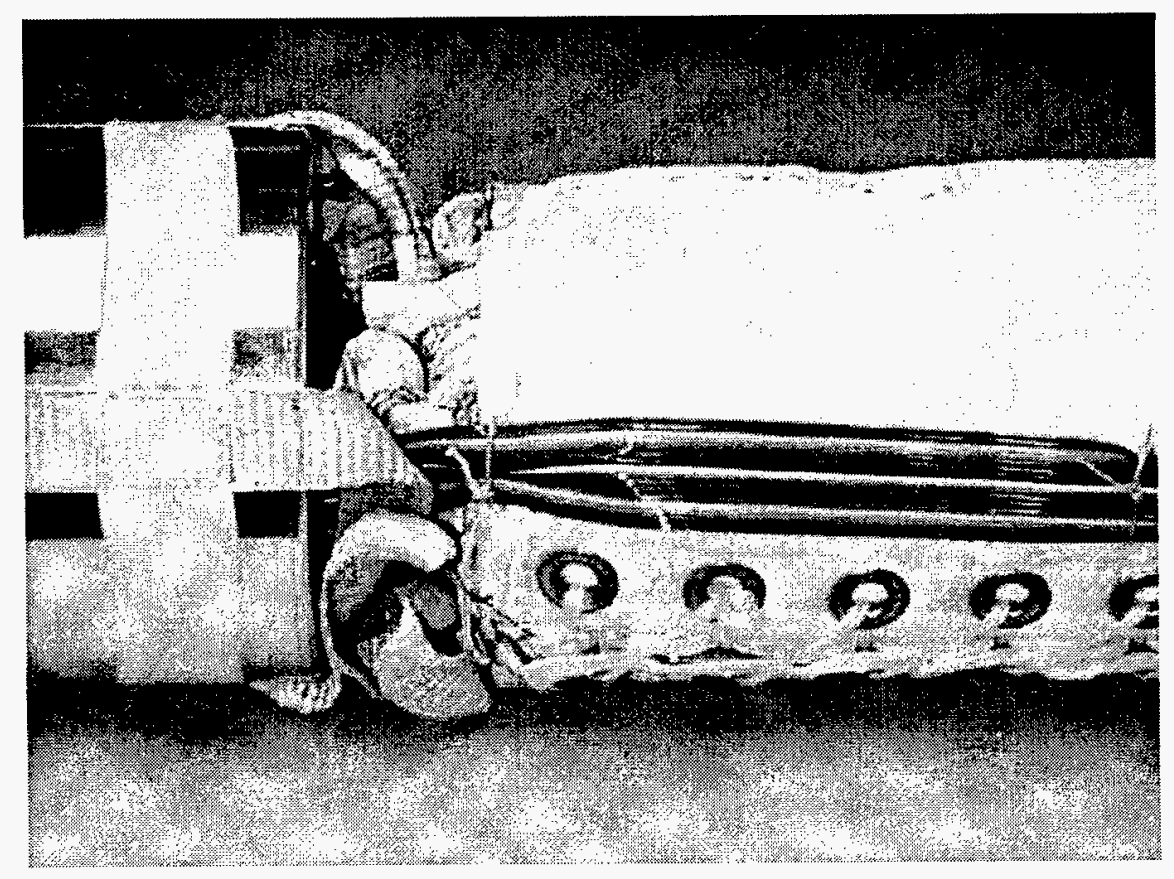

Figure 7 
9. Place the tube in a horizontal position. Align the ribbon wire on the TM pack and parachute with its termination block on the tube. Insert the TM pack and parachute into the tube arid slide in as far as possible. (See Figure 8)

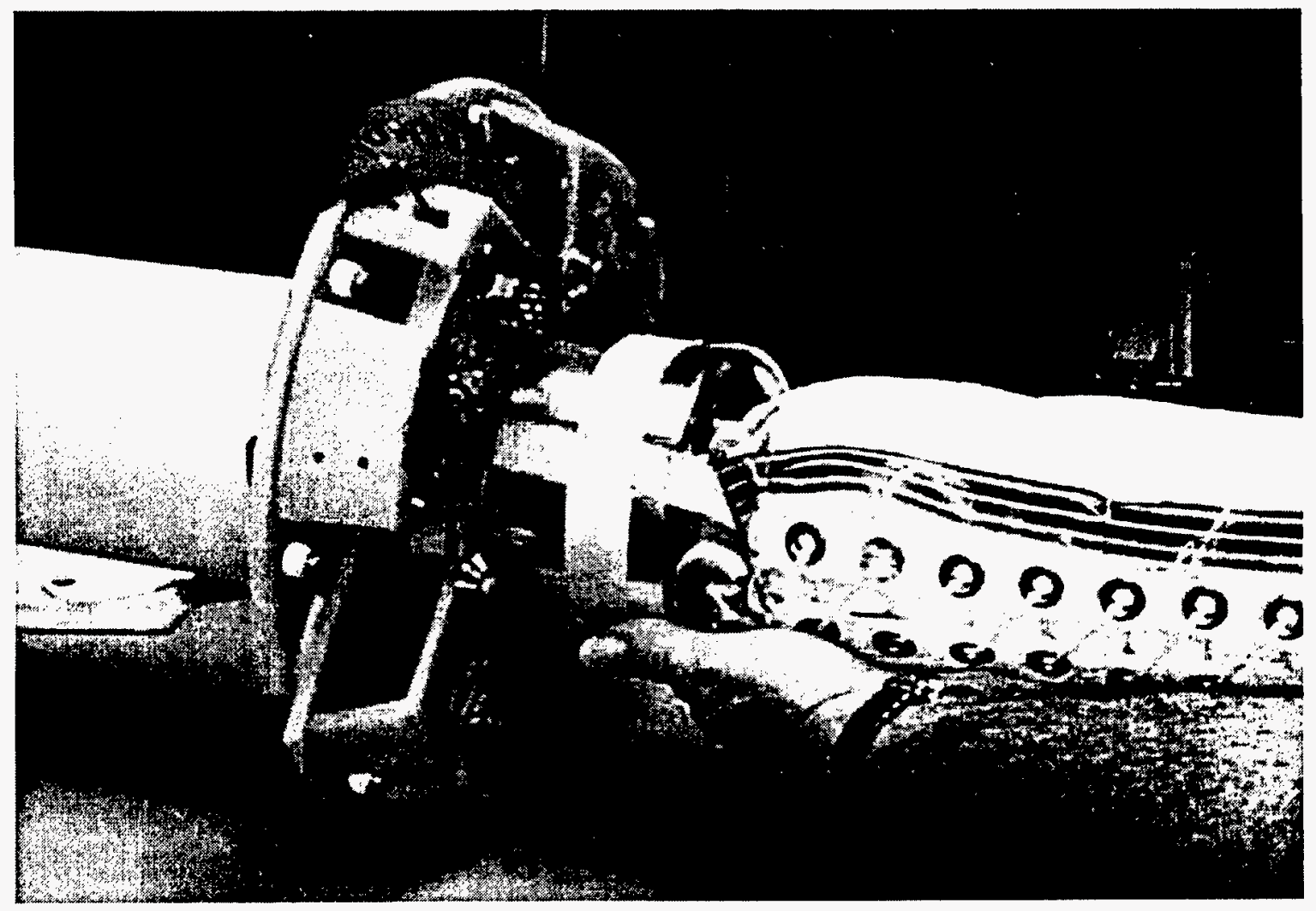

Figure 8 
10. Return the tube with the TM pack and parachute to an upright position. (See Figure 9)

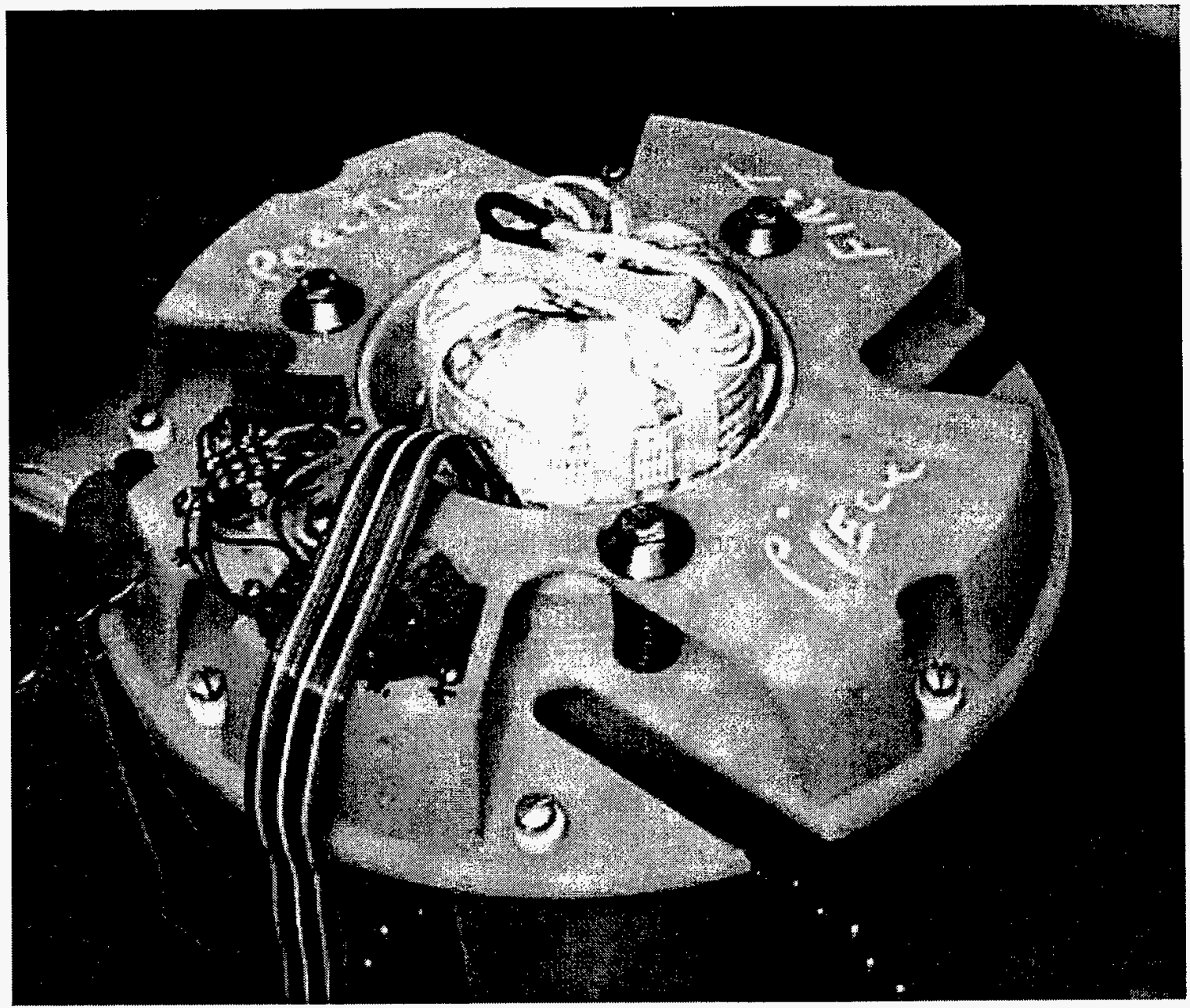

Figure 9 
11. Restrain the parachute in the tube by performing the following steps: (see Figure 10)

a. Cut two lengths of 1000-lb.-breaking-strength Kevlar braid. (approx. $3 \mathrm{ft}$. long)

b. Pass one end of one length down through an outside hole of the support plate, then back up through the inside hole of the plate.

c. Pass this end through the loop of one of the pilot chute release knives, through the loop of the pilot chute bridle and through the loop of the second pilot chute release knife.

d. Run this line across the pack and down through the inside hole and back up through the outside hole of the two holes diametrically opposed to the original two holes.

e. Run the end of this line back across the pack, passing through the knife loops and the pilot chute bridle loop again in the opposite direction.

f. Tie the ends together using a surgeon's knot, a locking knot and an overhand on each free end.

g. Safety the two overhand knots together using one turn of waxed Size 5 cord nylon thread.

h. Repeat this process with the second length of 1000-lb.-breaking-strength Kevlar braid through the remaining sets of holes in the plate.

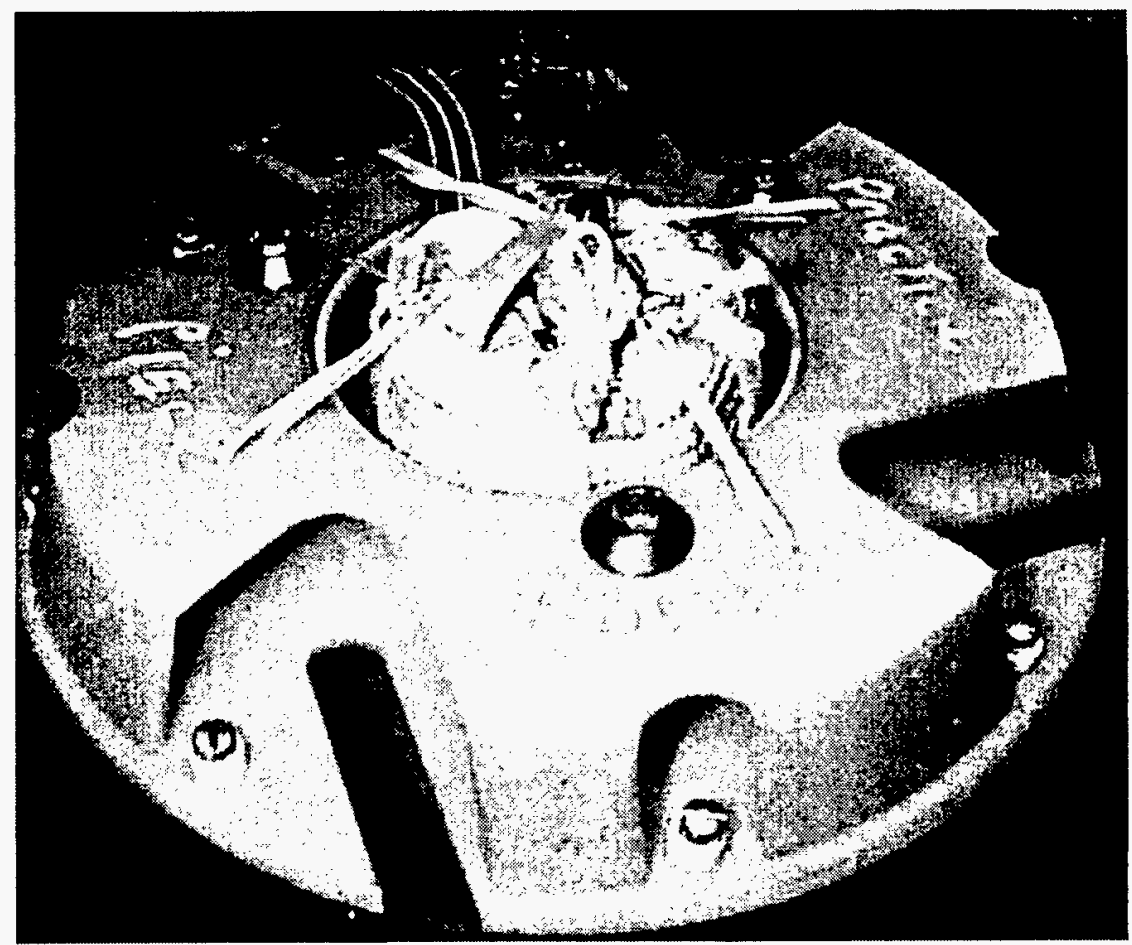

Figure 10 
12. After the terminal board has been installed and the electrical connections made, secure the ribbon wire to the spring place in two places with a single turn of waxed Size 5 nylon thread. Tie tightly with a binder's knot and a square knot. Tie the free ends together with an overhand knot. (See Figure 11)

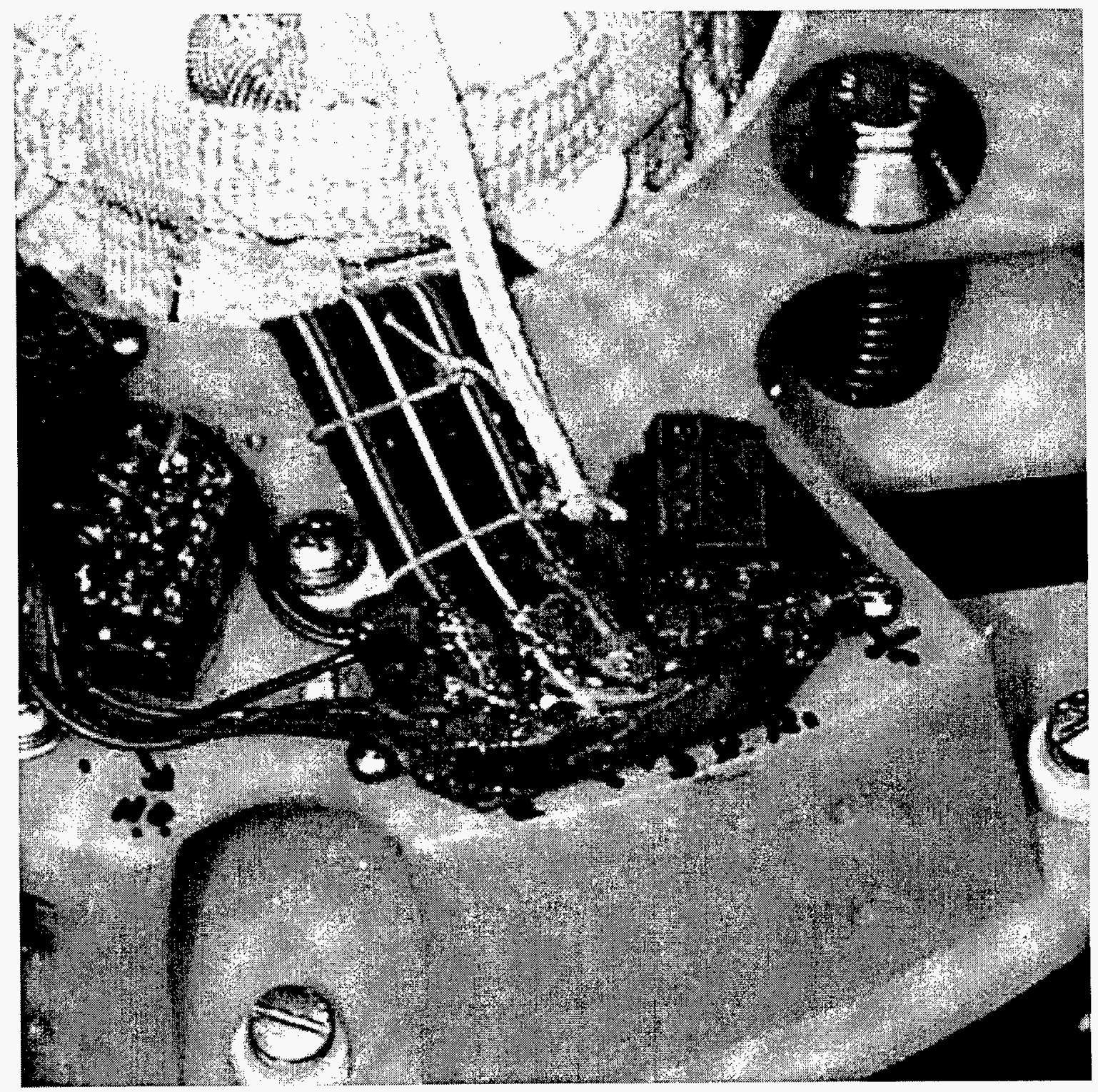

Figure 11 
Appendix C

Nominal WBS Trajectory 


\begin{tabular}{|c|c|c|c|c|c|c|c|}
\hline $\begin{array}{l}\text { Time from } \\
\text { Initiation } \\
\text { (sec) }\end{array}$ & $\begin{array}{c}\text { Forebody } \\
\text { Travel } \\
\text { Distance } \\
\text { (ft) }\end{array}$ & $\begin{array}{c}\text { TM Pack } \\
\text { Travel } \\
\text { Distance } \\
\text { (tt) }\end{array}$ & $\begin{array}{c}\text { Wire } \\
\text { Deployed } \\
\text { (ft) }\end{array}$ & $\begin{array}{c}\text { Main } \\
\text { Parachute } \\
\text { Diameter } \\
\text { (ft) }\end{array}$ & $\begin{array}{c}\text { Velocity of } \\
\text { Wire w/r/t } \\
\text { Ground } \\
\text { (fps) }\end{array}$ & $\begin{array}{c}\text { Main } \\
\text { Parachute } \\
\text { Drag Area } \\
\left(\mathrm{ft}^{\wedge} 2\right)\end{array}$ & Event \\
\hline 0.000 & 0 & 0 & 0 & 0.0 & 900 & 0.0 & $\begin{array}{l}\text { Initiate Deployment } \\
\text { Sequence }\end{array}$ \\
\hline 0.001 & 1 & 1 & 0 & 0.0 & 900 & 0.0 & \\
\hline 0.002 & 2 & 2 & 0 & 0.0 & 900 & 0.0 & \\
\hline 0.003 & 3 & 3 & 0 & 0.0 & 900 & 0.0 & \\
\hline 0.004 & 4 & 4 & 0 & 0.0 & 900 & 0.0 & \\
\hline 0.005 & 4 & 4 & 0 & 0.0 & 900 & 0.0 & \\
\hline 0.006 & 5 & 5 & 0 & 0.0 & 900 & 0.0 & \\
\hline 0.007 & 6 & 6 & 0 & 0.0 & 900 & 0.0 & \\
\hline 0.008 & 7 & 7 & 0 & 0.0 & 900 & 0.0 & \\
\hline 0.009 & 8 & 8 & 0 & 0.0 & 900 & 0.0 & \\
\hline 0.010 & 9 & 9 & 0 & 0.0 & 900 & 0.0 & \\
\hline 0.011 & 10 & 10 & 0 & 0.0 & 900 & 0.0 & \\
\hline 0.012 & 11 & 11 & 0 & 0.0 & 900 & 0.0 & \\
\hline 0.013 & 12 & 12 & 0 & 0.0 & 900 & 0.0 & \\
\hline 0.014 & 13 & 13 & 0 & 0.0 & 900 & 0.0 & \\
\hline 0.015 & 13 & 13 & 0 & 0.0 & 900 & 0.0 & \\
\hline 0.016 & 14 & 14 & 0 & 0.0 & 900 & 0.0 & \\
\hline 0.017 & 15 & 15 & 0 & 0.0 & 900 & 0.0 & \\
\hline 0.018 & 16 & 16 & 0 & 0.0 & 900 & 0.0 & \\
\hline 0.019 & 17 & 17 & 0 & 0.0 & 900 & 0.0 & \\
\hline 0.020 & 18 & 18 & 0 & 0.0 & 900 & 0.0 & \\
\hline 0.021 & 19 & 19 & 0 & 0.0 & 900 & 0.0 & \\
\hline 0.022 & 20 & 20 & 0 & 0.0 & 900 & 0.0 & \\
\hline 0.023 & 21 & 21 & 0 & 0.0 & 900 & 0.0 & \\
\hline 0.024 & 22 & 22 & 0 & 0.0 & 900 & 0.0 & \\
\hline 0.025 & 22 & 22 & 0 & 0.0 & 900 & 0.0 & \\
\hline 0.026 & 23 & 23 & 0 & 0.0 & 900 & 0.0 & \\
\hline 0.027 & 24 & 24 & 0 & 0.0 & 900 & 0.0 & \\
\hline 0.028 & 25 & 25 & 0 & 0.0 & 900 & 0.0 & \\
\hline 0.029 & 26 & 26 & 0 & 0.0 & 900 & 0.0 & \\
\hline 0.030 & 27 & 27 & 0 & 0.0 & 900 & 0.0 & \\
\hline 0.031 & 28 & 28 & 0 & 0.0 & 900 & 0.0 & \\
\hline 0.032 & 29 & 29 & 0 & 0.0 & 900 & 0.0 & \\
\hline 0.033 & 30 & 30 & 0 & 0.0 & 900 & 0.0 & \\
\hline 0.034 & 31 & 31 & 0 & 0.0 & 900 & 0.0 & \\
\hline 0.035 & 31 & 31 & 0 & 0.0 & 900 & 0.0 & \\
\hline 0.036 & 32 & 32 & 0 & 0.0 & 900 & 0.0 & \\
\hline 0.037 & 33 & 33 & 0 & 0.0 & 900 & 0.0 & \\
\hline 0.038 & 34 & 34 & 0 & 0.0 & 900 & 0.0 & \\
\hline 0.039 & 35 & 35 & 0 & 0.0 & 900 & 0.0 & \\
\hline 0.040 & 36 & 36 & 0 & 0.0 & 900 & 0.0 & \\
\hline 0.041 & 37 & 37 & 0 & 0.0 & 900 & 0.0 & \\
\hline 0.042 & 38 & 38 & 0 & 0.0 & 900 & 0.0 & \\
\hline 0.043 & 39 & 39 & 0 & 0.0 & 900 & 0.0 & \\
\hline 0.044 & 40 & 40 & 0 & 0.0 & 900 & 0.0 & \\
\hline 0.045 & 40 & 40 & 0 & 0.0 & 900 & 0.0 & \\
\hline 0.046 & 41 & 41 & 0 & 0.0 & 900 & 0.0 & \\
\hline 0.047 & 42 & 42 & 0 & 0.0 & 900 & 0.0 & \\
\hline 0.048 & 43 & 43 & 0 & 0.0 & 900 & 0.0 & \\
\hline 0.049 & 44 & 44 & 0 & 0.0 & 900 & 0.0 & \\
\hline 0.050 & 45 & 45 & 0 & 0.0 & 900 & 0.0 & \\
\hline 0.051 & 46 & 46 & 0 & 0.0 & 900 & 0.0 & \\
\hline 0.052 & 47 & 47 & 0 & 0.0 & 900 & 0.0 & \\
\hline 0.053 & 48 & 48 & 0 & 0.0 & 900 & 0.0 & \\
\hline 0.054 & 49 & 49 & 0 & 0.0 & 900 & 0.0 & \\
\hline 0.055 & 49 & 49 & 0 & 0.0 & 900 & 0.0 & \\
\hline 0.056 & 50 & 50 & 0 & 0.0 & 900 & 0.0 & \\
\hline 0.057 & 51 & 51 & 0 & 0.0 & 900 & 0.0 & \\
\hline 0.058 & 52 & 52 & 0 & 0.0 & 900 & 0.0 & \\
\hline 0.059 & 53 & 53 & 0 & 0.0 & 900 & 0.0 & \\
\hline 0.060 & 54 & 54 & 0 & 0.0 & 900 & 0.0 & \\
\hline
\end{tabular}




\begin{tabular}{|c|c|c|c|c|c|c|c|}
\hline $\begin{array}{c}\text { Time from } \\
\text { Initiation } \\
\text { (sec) }\end{array}$ & $\begin{array}{c}\text { Forebody } \\
\text { Travel } \\
\text { Distance } \\
\text { (ft) }\end{array}$ & $\begin{array}{c}\text { TM Pack } \\
\text { Travel } \\
\text { Distance } \\
\text { (ft) }\end{array}$ & $\begin{array}{c}\text { Wire } \\
\text { Deployed } \\
\text { (ft) }\end{array}$ & $\begin{array}{c}\text { Main } \\
\text { Parachute } \\
\text { Diameter } \\
\text { (ft) }\end{array}$ & $\begin{array}{l}\text { Velocity of } \\
\text { Wire w/r/t } \\
\text { Ground } \\
\text { (fps) }\end{array}$ & $\begin{array}{l}\text { Main } \\
\text { Parachute } \\
\text { Drag Area } \\
\left(t^{\wedge} 2\right)\end{array}$ & Event \\
\hline 0.061 & 55 & 55 & 0 & 0.0 & 900 & 0.0 & \\
\hline 0.062 & 56 & 56 & 0 & 0.0 & 900 & 0.0 & \\
\hline 0.063 & 57 & 57 & 0 & 0.0 & 900 & 0.0 & \\
\hline 0.064 & 58 & 58 & 0 & 0.0 & 900 & 0.0 & \\
\hline 0.065 & 58 & 58 & 0 & 0.0 & 900 & 0.0 & \\
\hline 0.066 & 59 & 59 & 0 & 0.0 & 900 & 0.0 & \\
\hline 0.067 & 60 & 60 & 0 & 0.0 & 900 & 0.0 & \\
\hline 0.068 & 61 & 61 & 0 & 0.0 & 900 & 0.0 & \\
\hline 0.069 & 62 & 62 & 0 & 0.0 & 900 & 0.0 & \\
\hline 0.070 & 63 & 63 & 0 & 0.0 & 900 & 0.0 & \\
\hline 0.071 & 64 & 64 & 0 & 0.0 & 900 & 0.0 & \\
\hline 0.072 & 65 & 65 & 0 & 0.0 & 900 & 0.0 & \\
\hline 0.073 & 66 & 66 & 0 & 0.0 & 900 & 0.0 & \\
\hline 0.074 & 67 & 67 & 0 & 0.0 & 900 & 0.0 & \\
\hline 0.075 & 68 & 68 & 0 & 0.0 & 900 & 0.0 & \\
\hline 0.076 & 68 & 68 & 0 & 0.0 & 900 & 0.0 & \\
\hline 0.077 & 69 & 69 & 0 & 0.0 & 900 & 0.0 & \\
\hline 0.078 & 70 & 70 & 0 & 0.0 & 900 & 0.0 & \\
\hline 0.079 & 71 & 71 & 0 & 0.0 & 900 & 0.0 & \\
\hline 0.080 & 72 & 72 & 0 & 0.0 & 900 & 0.0 & \\
\hline 0.081 & 73 & 73 & 0 & 0.0 & 900 & 0.0 & \\
\hline 0.082 & 74 & 74 & 0 & 0.0 & 900 & 0.0 & $\begin{array}{l}\text { Pilot Chute } \\
\text { Canopy Stretch }\end{array}$ \\
\hline 0.083 & 75 & 75 & 0 & 0.0 & 900 & 0.0 & \\
\hline 0.084 & 76 & 76 & 0 & 0.0 & 900 & 0.0 & \\
\hline 0.085 & 77 & 77 & 0 & 0.0 & 900 & 0.0 & \\
\hline 0.086 & 77 & 77 & 0 & 0.0 & 900 & 0.0 & \\
\hline 0.087 & 78 & 78 & 0 & 0.0 & 900 & 0.0 & \\
\hline 0.088 & 79 & 79 & 0 & 0.0 & 900 & 0.0 & \\
\hline 0.089 & 80 & 80 & 0 & 0.0 & 900 & 0.0 & \\
\hline 0.090 & 81 & 81 & 0 & 0.0 & 900 & 0.0 & \\
\hline 0.091 & 82 & 82 & 0 & 0.0 & 900 & 0.0 & \\
\hline 0.092 & 83 & 83 & 0 & 0.0 & 900 & 0.0 & \\
\hline 0.093 & 84 & 84 & 0 & 0.0 & 900 & 0.0 & \\
\hline 0.094 & 85 & 85 & 0 & 0.0 & 900 & 0.0 & \\
\hline 0.095 & 86 & 86 & 0 & 0.0 & 900 & 0.0 & \\
\hline 0.096 & 86 & 86 & 0 & 0.0 & 900 & 0.0 & \\
\hline 0.097 & 87 & 87 & 0 & 0.0 & 900 & 0.0 & \\
\hline 0.098 & 88 & 88 & 0 & 0.0 & 900 & 0.0 & \\
\hline 0.099 & 89 & 89 & 0 & 0.0 & 900 & 0.0 & \\
\hline 0.100 & 90 & 90 & 0 & 0.0 & 900 & 0.0 & $\begin{array}{l}\text { Pilot Chute Canopy } \\
\text { Fill }\end{array}$ \\
\hline 0.101 & 91 & 91 & 0 & 0.0 & 900 & 0.0 & \\
\hline 0.102 & 92 & 92 & 0 & 0.0 & 900 & 0.0 & \\
\hline 0.103 & 93 & 93 & 0 & 0.0 & 900 & 0.0 & \\
\hline 0.104 & 94 & 94 & 0 & 0.0 & 900 & 0.0 & \\
\hline 0.105 & 95 & 95 & 0 & 0.0 & 900 & 0.0 & \\
\hline 0.106 & 95 & 95 & 0 & 0.0 & 900 & 0.0 & \\
\hline 0.107 & 96 & 96 & 0 & 0.0 & 900 & 0.0 & \\
\hline 0.108 & 97 & 97 & 0 & 0.0 & 900 & 0.0 & \\
\hline 0.109 & 98 & 98 & 0 & 0.0 & 900 & 0.0 & \\
\hline 0.110 & 99 & 99 & 0 & 0.0 & 900 & 0.0 & \\
\hline 0.111 & 100 & 100 & 0 & 0.0 & 900 & 0.0 & \\
\hline 0.112 & 101 & 101 & 0 & 0.0 & 900 & 0.0 & \\
\hline 0.113 & 102 & 102 & 0 & 0.0 & 900 & 0.0 & \\
\hline 0.114 & 103 & 103 & 0 & 0.0 & 900 & 0.0 & \\
\hline 0.115 & 104 & 104 & 0 & 0.0 & 899 & 0.0 & \\
\hline 0.116 & 104 & 104 & 0 & 0.0 & 899 & 0.0 & \\
\hline 0.117 & 105 & 105 & 0 & 0.0 & 899 & 0.0 & \\
\hline 0.118 & 106 & 106 & 0 & 0.0 & 899 & 0.0 & \\
\hline 0.119 & 107 & 107 & 0 & 0.0 & 899 & 0.0 & \\
\hline 0.120 & 108 & 108 & 0 & 0.0 & 899 & 0.0 & \\
\hline
\end{tabular}




\begin{tabular}{|c|c|c|c|c|c|c|c|}
\hline $\begin{array}{c}\text { Time from } \\
\text { Initiation } \\
\text { (sec) }\end{array}$ & $\begin{array}{c}\text { Forebody } \\
\text { Travel } \\
\text { Distance } \\
\text { (ft) }\end{array}$ & $\begin{array}{l}\text { TM Pack } \\
\text { Travel } \\
\text { Distance } \\
\text { (ft) }\end{array}$ & $\begin{array}{c}\text { Wire } \\
\text { Deployed } \\
\text { (ft) }\end{array}$ & $\begin{array}{c}\text { Main } \\
\text { Parachute } \\
\text { Diameter } \\
\text { (ft) }\end{array}$ & $\begin{array}{l}\text { Velocity of } \\
\text { Wire w/r/t } \\
\text { Ground } \\
\text { (fps) }\end{array}$ & $\begin{array}{c}\text { Main } \\
\text { Parachute } \\
\text { Drag Area } \\
\left(\mathrm{ft}^{\wedge} 2\right)\end{array}$ & Event \\
\hline 0.121 & 109 & 109 & 0 & 0.0 & 898 & 0.0 & \\
\hline 0.122 & 110 & 110 & 0 & 0.0 & 898 & 0.0 & \\
\hline 0.123 & 111 & 111 & 0 & 0.0 & 898 & 0.0 & \\
\hline 0.124 & 112 & 112 & 0 & 0.0 & 898 & 0.0 & \\
\hline 0.125 & 113 & 113 & 0 & 0.0 & 897 & 0.0 & \\
\hline 0.126 & 113 & 113 & 0 & 0.0 & 897 & 0.0 & \\
\hline 0.127 & 114 & 114 & 0 & 0.0 & 897 & 0.0 & \\
\hline 0.128 & 115 & 115 & 0 & 0.0 & 896 & 0.0 & \\
\hline 0.129 & 116 & 116 & 0 & 0.0 & 896 & 0.0 & \\
\hline 0.130 & 117 & 117 & 0 & 0.0 & 896 & 0.0 & \\
\hline 0.131 & 118 & 118 & 0 & 0.0 & 895 & 0.0 & \\
\hline 0.132 & 119 & 119 & 0 & 0.0 & 895 & 0.0 & \\
\hline 0.133 & 120 & 120 & 0 & 0.0 & 895 & 0.0 & \\
\hline 0.134 & 121 & 121 & 0 & 0.0 & 894 & 0.0 & \\
\hline 0.135 & 122 & 121 & 0 & 0.0 & 894 & 0.0 & \\
\hline 0.136 & 122 & 122 & 0 & 0.0 & 893 & 0.0 & \\
\hline 0.137 & 123 & 123 & 0 & 0.0 & 893 & 0.0 & \\
\hline 0.138 & 124 & 124 & 0 & 0.0 & 893 & 0.0 & \\
\hline 0.139 & 125 & 125 & 0 & 0.0 & 892 & 0.0 & \\
\hline 0.140 & 126 & 126 & 0 & 0.0 & 892 & 0.0 & \\
\hline 0.141 & 127 & 127 & 0 & 0.0 & 891 & 0.0 & \\
\hline 0.142 & 128 & 128 & 0 & 0.0 & 891 & 0.0 & \\
\hline 0.143 & 129 & 129 & 0 & 0.0 & 890 & 0.0 & \\
\hline 0.144 & 130 & 130 & 0 & 0.0 & 890 & 0.0 & \\
\hline 0.145 & 131 & 130 & 0 & 0.0 & 889 & 0.0 & \\
\hline 0.146 & 131 & 131 & 0 & 0.0 & 888 & 0.0 & \\
\hline 0.147 & 132 & 132 & 0 & 0.0 & 888 & 0.0 & \\
\hline 0.148 & 133 & 133 & 0 & 0.0 & 887 & 0.0 & \\
\hline 0.149 & 134 & 134 & 0 & 0.0 & 887 & 0.0 & \\
\hline 0.150 & 135 & 135 & 0 & 0.0 & 886 & 0.0 & \\
\hline 0.151 & 136 & 136 & 0 & 0.0 & 885 & 0.0 & \\
\hline 0.152 & 137 & 137 & 0 & 0.0 & 885 & 0.0 & \\
\hline 0.153 & 138 & 137 & 0 & 0.0 & 884 & 0.0 & \\
\hline 0.154 & 139 & 138 & 0 & 0.0 & 883 & 0.0 & \\
\hline 0.155 & 140 & 139 & 0 & 0.0 & 883 & 0.0 & \\
\hline 0.156 & 140 & 140 & 0 & 0.0 & 882 & 0.0 & \\
\hline 0.157 & 141 & 141 & 0 & 0.0 & 881 & 0.0 & \\
\hline 0.158 & 142 & 142 & 0 & 0.0 & 881 & 0.0 & \\
\hline 0.159 & 143 & 143 & 0 & 0.0 & 880 & 0.0 & \\
\hline 0.160 & 144 & 144 & 0 & 0.0 & 879 & 0.0 & \\
\hline 0.161 & 145 & 145 & 0 & 0.0 & 878 & 0.0 & \\
\hline 0.162 & 146 & 145 & 0 & 0.0 & 878 & 0.0 & \\
\hline 0.163 & 147 & 146 & 0 & 0.0 & 873 & 0.0 & \\
\hline 0.164 & 148 & 147 & 1 & 0.0 & 869 & 0.0 & \\
\hline 0.165 & 149 & 148 & 1 & 0.0 & 865 & 0.0 & \\
\hline 0.166 & 149 & 149 & 1 & 0.0 & 861 & 0.0 & \\
\hline 0.167 & 150 & 150 & 1 & 0.0 & 857 & 0.0 & \\
\hline 0.168 & 151 & 151 & 1 & 0.0 & 853 & 0.0 & \\
\hline 0.169 & 152 & 151 & 1 & 0.0 & 850 & 0.0 & \\
\hline 0.170 & 153 & 152 & 1 & 0.0 & 846 & 0.0 & \\
\hline 0.171 & 154 & 153 & 1 & 0.0 & 842 & 0.0 & \\
\hline 0.172 & 155 & 154 & 1 & 0.0 & 838 & 0.0 & \\
\hline 0.173 & 156 & 155 & 1 & 0.0 & 834 & 0.0 & $\begin{array}{l}\text { Main Parachute } \\
\text { Canopy Stretch }\end{array}$ \\
\hline 0.174 & 157 & 156 & 1 & 0.0 & 817 & 0.9 & \\
\hline 0.175 & 157 & 156 & 1 & 0.6 & 815 & 1.3 & \\
\hline 0.176 & 158 & 157 & 1 & 0.8 & 811 & 1.6 & \\
\hline 0.177 & 159 & 158 & 1 & 1.0 & 808 & 2.0 & \\
\hline 0.178 & 160 & 159 & 1 & 1.2 & 803 & 2.4 & \\
\hline 0.179 & 161 & 160 & 1 & 1.3 & 798 & 2.7 & \\
\hline 0.180 & 162 & 160 & 2 & 1.5 & 792 & 3.1 & \\
\hline
\end{tabular}




\begin{tabular}{|c|c|c|c|c|c|c|}
\hline $\begin{array}{c}\text { Time from } \\
\text { Initiation } \\
\text { (sec) }\end{array}$ & $\begin{array}{c}\text { Forebody } \\
\text { Travel } \\
\text { Distance } \\
\text { (ft) }\end{array}$ & $\begin{array}{c}\text { TM Pack } \\
\text { Travel } \\
\text { Distance } \\
\text { (ft) }\end{array}$ & $\begin{array}{c}\text { Wire } \\
\text { Deployed } \\
(\mathrm{ft})\end{array}$ & $\begin{array}{c}\text { Main } \\
\text { Parachute } \\
\text { Diameter } \\
(\mathrm{ft})\end{array}$ & $\begin{array}{c}\text { Velocity of } \\
\text { Wire w/r/t } \\
\text { Ground } \\
\text { (fps) }\end{array}$ & $\begin{array}{c}\text { Main } \\
\text { Parachute } \\
\text { Drag Area } \\
\left(\mathrm{f}^{\wedge} 2\right)\end{array}$ \\
\hline 0.181 & 163 & 161 & 2 & 1.6 & 786 & 3.5 \\
\hline 0.182 & 164 & 162 & 2 & 1.7 & 779 & 3.8 \\
\hline 0.183 & 165 & 163 & 2 & 1.8 & 772 & 4.2 \\
\hline 0.184 & 166 & 164 & 2 & 1.9 & 764 & 4.5 \\
\hline 0.185 & 166 & 164 & 2 & 2.0 & 756 & 4.9 \\
\hline 0.186 & 167 & 165 & 2 & 2.0 & 748 & 5.2 \\
\hline 0.187 & 168 & 166 & 3 & 2.1 & 739 & 5.6 \\
\hline 0.188 & 169 & 166 & 3 & 2.2 & 729 & 5.9 \\
\hline 0.189 & 170 & 167 & 3 & 2.3 & 720 & 6.2 \\
\hline 0.190 & 171 & 168 & 3 & 2.3 & 710 & 6.6 \\
\hline 0.191 & 172 & 169 & 3 & 2.4 & 700 & 6.9 \\
\hline 0.192 & 173 & 169 & 3 & 2.5 & 690 & 7.2 \\
\hline 0.193 & 174 & 170 & 4 & 2.5 & 680 & 7.5 \\
\hline 0.194 & 175 & 171 & 4 & 2.6 & 669 & 7.8 \\
\hline 0.195 & 175 & 171 & 4 & 2.6 & 659 & 8.1 \\
\hline 0.196 & 176 & 172 & 4 & 2.7 & 648 & 8.4 \\
\hline 0.197 & 177 & 173 & 5 & 2.7 & 638 & 8.7 \\
\hline 0.198 & 178 & 173 & 5 & 2.8 & 627 & 9.0 \\
\hline 0.199 & 179 & 174 & 5 & 2.8 & 617 & 9.3 \\
\hline 0.200 & 180 & 175 & 5 & 2.9 & 606 & 9.6 \\
\hline 0.201 & 181 & 175 & 6 & 2.9 & 596 & 9.9 \\
\hline 0.202 & 182 & 176 & 6 & 3.0 & 585 & 10.1 \\
\hline 0.203 & 183 & 176 & 6 & 3.0 & 575 & 10.4 \\
\hline 0.204 & 184 & 177 & 7 & 3.1 & 565 & 10.7 \\
\hline 0.205 & 184 & 177 & 7 & 3.1 & 555 & 10.9 \\
\hline 0.206 & 185 & 178 & 7 & 3.1 & 545 & 11.2 \\
\hline 0.207 & 186 & 179 & 8 & 3.2 & 535 & 11.4 \\
\hline 0.208 & 187 & 179 & 8 & 3.2 & 526 & 11.7 \\
\hline 0.209 & 188 & 180 & 9 & 3.3 & 516 & 11.9 \\
\hline 0.210 & 189 & 180 & 9 & 3.3 & 507 & 12.1 \\
\hline 0.211 & 190 & 181 & 9 & 3.3 & 498 & 12.4 \\
\hline 0.212 & 191 & 181 & 10 & 3.4 & 489 & 12.6 \\
\hline 0.213 & 192 & 182 & 10 & 3.4 & 480 & 12.8 \\
\hline 0.214 & 193 & 182 & 11 & 3.4 & 472 & 13.0 \\
\hline 0.215 & 193 & 183 & 11 & 3.5 & 463 & 13.3 \\
\hline 0.216 & 194 & 183 & 11 & 3.5 & 455 & 13.5 \\
\hline 0.217 & 195 & 184 & 12 & 3.5 & 447 & 13.7 \\
\hline 0.218 & 196 & 184 & 12 & 3.5 & 439 & 13.9 \\
\hline 0.219 & 197 & 184 & 13 & 3.6 & 431 & 14.1 \\
\hline 0.220 & 198 & 185 & 13 & 3.6 & 424 & 14.3 \\
\hline 0.221 & 199 & 185 & 14 & 3.6 & 416 & 14.5 \\
\hline 0.222 & 200 & 186 & 14 & 3.6 & 409 & 14.7 \\
\hline 0.223 & 201 & 186 & 15 & 3.7 & 402 & 14.9 \\
\hline 0.224 & 202 & 186 & 15 & 3.7 & 395 & 15.0 \\
\hline 0.225 & 203 & 187 & 16 & 3.7 & 388 & 15.2 \\
\hline 0.226 & 203 & 187 & 16 & 3.7 & 382 & 15.4 \\
\hline 0.227 & 204 & 188 & 17 & 3.8 & 375 & 15.6 \\
\hline 0.228 & 205 & 188 & 17 & 3.8 & 369 & 15.7 \\
\hline 0.229 & 206 & 188 & 18 & 3.8 & 363 & 15.9 \\
\hline 0.230 & 207 & 189 & 18 & 3.8 & 357 & 16.1 \\
\hline 0.231 & 208 & 189 & 19 & 3.8 & 351 & 16.2 \\
\hline 0.232 & 209 & 189 & 19 & 3.9 & 345 & 16.4 \\
\hline 0.233 & 210 & 190 & 20 & 3.9 & 340 & 16.6 \\
\hline 0.234 & 211 & 190 & 21 & 3.9 & 335 & 16.7 \\
\hline 0.235 & 212 & 190 & 21 & 3.9 & 329 & 16.9 \\
\hline 0.236 & 212 & 191 & 22 & 3.9 & 324 & 17.0 \\
\hline 0.237 & 213 & 191 & 22 & 4.0 & 319 & 17.2 \\
\hline 0.238 & 214 & 191 & 23 & 4.0 & 314 & 17.3 \\
\hline 0.239 & 215 & 192 & 23 & 4.0 & 309 & 17.5 \\
\hline 0.240 & 216 & 192 & 24 & 4.0 & 305 & 17.6 \\
\hline 0.241 & 217 & 192 & 25 & 4.0 & 300 & 17.7 \\
\hline 0.242 & 218 & 193 & 25 & 4.0 & 295 & 17.9 \\
\hline 0.243 & 219 & 193 & 26 & 4.1 & 291 & 18.0 \\
\hline 0.244 & 220 & 193 & 26 & 4.1 & 287 & 18.1 \\
\hline 0.245 & 221 & 193 & 27 & 4.1 & 283 & 18.3 \\
\hline
\end{tabular}




\begin{tabular}{|c|c|c|c|c|c|c|}
\hline $\begin{array}{c}\text { Time from } \\
\text { Initiation } \\
\text { (sec) }\end{array}$ & $\begin{array}{l}\text { Forebody } \\
\text { Travel } \\
\text { Distance } \\
\text { (ft) }\end{array}$ & $\begin{array}{c}\text { TM Pack } \\
\text { Travel } \\
\text { Distance } \\
\text { (ft) }\end{array}$ & $\begin{array}{c}\text { Wire } \\
\text { Deployed } \\
(f t)\end{array}$ & $\begin{array}{c}\text { Main } \\
\text { Parachute } \\
\text { Diameter } \\
\text { (ft) }\end{array}$ & $\begin{array}{l}\text { Velocity of } \\
\text { Wire w/r/t } \\
\text { Ground } \\
\text { (fps) }\end{array}$ & $\begin{array}{c}\text { Main } \\
\text { Parachute } \\
\text { Drag Area } \\
\left(t^{\wedge} 2\right)\end{array}$ \\
\hline 0.246 & 221 & 194 & 28 & 4.1 & 279 & 18.4 \\
\hline 0.247 & 222 & 194 & 28 & 4.1 & 275 & 18.5 \\
\hline 0.248 & 223 & 194 & 29 & 4.1 & 271 & 18.6 \\
\hline 0.249 & 224 & 195 & 30 & 4.1 & 267 & 18.8 \\
\hline 0.250 & 225 & 195 & 30 & 4.2 & 263 & 18.9 \\
\hline 0.251 & 226 & 195 & 31 & 4.2 & 260 & 19.0 \\
\hline 0.252 & 227 & 195 & 32 & 4.2 & 256 & 19.1 \\
\hline 0.253 & 228 & 196 & 32 & 4.2 & 253 & 19.2 \\
\hline 0.254 & 229 & 196 & 33 & 4.2 & 249 & 19.4 \\
\hline 0.255 & 230 & 196 & 33 & 4.2 & 246 & 19.5 \\
\hline 0.256 & 230 & 196 & 34 & 4.2 & 243 & 19.6 \\
\hline 0.257 & 231 & 197 & 35 & 4.3 & 239 & 19.7 \\
\hline 0.258 & 232 & 197 & 35 & 4.3 & 236 & 19.8 \\
\hline 0.259 & 233 & 197 & 36 & 4.3 & 233 & 19.9 \\
\hline 0.260 & 234 & 197 & 37 & 4.3 & 230 & 20.0 \\
\hline 0.261 & 235 & 197 & 37 & 4.3 & 228 & 20.1 \\
\hline 0.262 & 236 & 198 & 38 & 4.3 & 225 & 20.2 \\
\hline 0.263 & 237 & 198 & 39 & 4.3 & 222 & 20.3 \\
\hline 0.264 & 238 & 198 & 39 & 4.3 & 219 & 20.4 \\
\hline 0.265 & 239 & 198 & 40 & 4.3 & 217 & 20.5 \\
\hline 0.266 & 239 & 199 & 41 & 4.4 & 214 & 20.6 \\
\hline 0.267 & 240 & 199 & 42 & 4.4 & 211 & 20.7 \\
\hline 0.268 & 241 & 199 & 42 & 4.4 & 209 & 20.8 \\
\hline 0.269 & 242 & 199 & 43 & 4.4 & 206 & 20.9 \\
\hline 0.270 & 243 & 199 & 44 & 4.4 & 204 & 21.0 \\
\hline 0.271 & 244 & 200 & 44 & 4.4 & 202 & 21.1 \\
\hline 0.272 & 245 & 200 & 45 & 4.4 & 199 & 21.2 \\
\hline 0.273 & 246 & 200 & 46 & 4.4 & 197 & 21.3 \\
\hline 0.274 & 247 & 200 & 46 & 4.4 & 195 & 21.4 \\
\hline 0.275 & 248 & 200 & 47 & 4.5 & 193 & 21.5 \\
\hline 0.276 & 248 & 201 & 48 & 4.5 & 191 & 21.6 \\
\hline 0.277 & 249 & 201 & 49 & 4.5 & 189 & 21.6 \\
\hline 0.278 & 250 & 201 & 49 & 4.5 & 187 & 21.7 \\
\hline 0.279 & 251 & 201 & 50 & 4.5 & 185 & 21.8 \\
\hline 0.280 & 252 & 201 & 51 & 4.5 & 183 & 21.9 \\
\hline 0.281 & 253 & 202 & 51 & 4.5 & 181 & 22.0 \\
\hline 0.282 & 254 & 202 & 52 & 4.5 & 179 & 22.1 \\
\hline 0.283 & 255 & 202 & 53 & 4.5 & 177 & 22.1 \\
\hline 0.284 & 256 & 202 & 54 & 4.5 & 175 & 22.2 \\
\hline 0.285 & 257 & 202 & 54 & 4.5 & 174 & 22.3 \\
\hline 0.286 & 257 & 202 & 55 & 4.5 & 172 & 22.4 \\
\hline 0.287 & 258 & 203 & 56 & 4.6 & 170 & 22.5 \\
\hline 0.288 & 259 & 203 & 56 & 4.6 & 169 & 22.5 \\
\hline 0.289 & 260 & 203 & 57 & 4.6 & 167 & 22.6 \\
\hline 0.290 & 261 & 203 & 58 & 4.6 & 165 & 22.7 \\
\hline 0.291 & 262 & 203 & 59 & 4.6 & 164 & 22.8 \\
\hline 0.292 & 263 & 203 & 59 & 4.6 & 162 & 22.8 \\
\hline 0.293 & 264 & 204 & 60 & 4.6 & 161 & 22.9 \\
\hline 0.294 & 265 & 204 & 61 & 4.6 & 159 & 23.0 \\
\hline 0.295 & 266 & 204 & 62 & 4.6 & 158 & 23.1 \\
\hline 0.296 & 266 & 204 & 62 & 4.6 & 156 & 23.1 \\
\hline 0.297 & 267 & 204 & 63 & 4.6 & 155 & 23.2 \\
\hline 0.298 & 268 & 204 & 64 & 4.6 & 153 & 23.3 \\
\hline 0.299 & 269 & 205 & 65 & 4.7 & 152 & 23.3 \\
\hline 0.300 & 270 & 205 & 65 & 4.7 & 151 & 23.4 \\
\hline 0.301 & 271 & 205 & 66 & 4.7 & 149 & 23.5 \\
\hline 0.302 & 272 & 205 & 67 & 4.7 & 148 & 23.6 \\
\hline 0.303 & 273 & 205 & 68 & 4.7 & 147 & 23.6 \\
\hline 0.304 & 274 & 205 & 68 & 4.7 & 146 & 23.7 \\
\hline 0.305 & 275 & 205 & 69 & 4.7 & 144 & 23.8 \\
\hline 0.306 & 275 & 206 & 70 & 4.7 & 143 & 23.8 \\
\hline 0.307 & 276 & 206 & 71 & 4.7 & 142 & 23.9 \\
\hline
\end{tabular}




\begin{tabular}{|c|c|c|c|c|c|c|}
\hline $\begin{array}{c}\text { Time from } \\
\text { Initiation } \\
\text { (sec) }\end{array}$ & $\begin{array}{c}\text { Forebody } \\
\text { Travel } \\
\text { Distance } \\
\text { (ft) }\end{array}$ & $\begin{array}{l}\text { TM Pack } \\
\text { Travel } \\
\text { Distance } \\
\text { (ft) }\end{array}$ & $\begin{array}{c}\text { Wire } \\
\text { Deployed } \\
\text { (ft) }\end{array}$ & $\begin{array}{c}\text { Main } \\
\text { Parachute } \\
\text { Diameter } \\
\text { (ft) }\end{array}$ & $\begin{array}{c}\text { Velocity of } \\
\text { Wire } w / r / t \\
\text { Ground } \\
\text { (fps) }\end{array}$ & $\begin{array}{c}\text { Main } \\
\text { Parachute } \\
\text { Drag Area } \\
\left(H^{\wedge} 2\right)\end{array}$ \\
\hline 0.308 & 277 & 206 & 71 & 4.7 & 141 & 23.9 \\
\hline 0.309 & 278 & 206 & 72 & 4.7 & 140 & 24.0 \\
\hline 0.310 & 279 & 206 & 73 & 4.7 & 139 & 24.1 \\
\hline 0.311 & 280 & 206 & 74 & 4.7 & 137 & 24.1 \\
\hline 0.312 & 281 & 206 & 74 & 4.7 & 136 & 24.2 \\
\hline 0.313 & 282 & 207 & 75 & 4.7 & 135 & 24.3 \\
\hline 0.314 & 283 & 207 & 76 & 4.8 & 134 & 24.3 \\
\hline 0.315 & 284 & 207 & 77 & 4.8 & 133 & 24.4 \\
\hline 0.316 & 284 & 207 & 78 & 4.8 & 132 & 24.4 \\
\hline 0.317 & 285 & 207 & 78 & 4.8 & 131 & 24.5 \\
\hline 0.318 & 286 & 207 & 79 & 4.8 & 130 & 24.6 \\
\hline 0.319 & 287 & 207 & 80 & 4.8 & 129 & 24.6 \\
\hline 0.320 & 288 & 208 & 81 & 4.8 & 128 & 24.7 \\
\hline 0.321 & 289 & 208 & 81 & 4.8 & 127 & 24.7 \\
\hline 0.322 & 290 & 208 & 82 & 4.8 & 126 & 24.8 \\
\hline 0.323 & 291 & 208 & 83 & 4.8 & 125 & 24.9 \\
\hline 0.324 & 292 & 208 & 84 & 4.8 & 125 & 24.9 \\
\hline 0.325 & 293 & 208 & 84 & 4.8 & 124 & 25.0 \\
\hline 0.326 & 294 & 208 & 85 & 4.8 & 123 & 25.0 \\
\hline 0.327 & 294 & 208 & 86 & 4.8 & 122 & 25.1 \\
\hline 0.328 & 295 & 209 & 87 & 4.8 & 121 & 25.1 \\
\hline 0.329 & 296 & 209 & 88 & 4.8 & 120 & 25.2 \\
\hline 0.330 & 297 & 209 & 88 & 4.8 & 119 & 25.2 \\
\hline 0.331 & 298 & 209 & 89 & 4.8 & 119 & 25.3 \\
\hline 0.332 & 299 & 209 & 90 & 4.9 & 118 & 25.4 \\
\hline 0.333 & 300 & 209 & 91 & 4.9 & 117 & 25.4 \\
\hline 0.334 & 301 & 209 & 92 & 4.9 & 116 & 25.5 \\
\hline 0.335 & 302 & 209 & 92 & 4.9 & 116 & 25.5 \\
\hline 0.336 & 303 & 209 & 93 & 4.9 & 115 & 25.6 \\
\hline 0.337 & 303 & 210 & 94 & 4.9 & 114 & 25.6 \\
\hline 0.338 & 304 & 210 & 95 & 4.9 & 113 & 25.7 \\
\hline 0.339 & 305 & 210 & 95 & 4.9 & 113 & 25.7 \\
\hline 0.340 & 306 & 210 & 96 & 4.9 & 112 & 25.8 \\
\hline 0.341 & 307 & 210 & 97 & 4.9 & 111 & 25.8 \\
\hline 0.342 & 308 & 210 & 98 & 4.9 & 111 & 25.9 \\
\hline 0.343 & 309 & 210 & 99 & 4.9 & 110 & 25.9 \\
\hline 0.344 & 310 & 210 & 99 & 4.9 & 109 & 26.0 \\
\hline 0.345 & 311 & 211 & 100 & 4.9 & 109 & 26.0 \\
\hline 0.346 & 312 & 211 & 101 & 4.9 & 108 & 26.1 \\
\hline 0.347 & 312 & 211 & 102 & 4.9 & 107 & 26.1 \\
\hline 0.348 & 313 & 211 & 103 & 4.9 & 107 & 26.2 \\
\hline 0.349 & 314 & 211 & 103 & 4.9 & 106 & 26.2 \\
\hline 0.350 & 315 & 211 & 104 & 4.9 & 105 & 26.3 \\
\hline 0.351 & 316 & 211 & 105 & 4.9 & 105 & 26.3 \\
\hline 0.352 & 317 & 211 & 106 & 5.0 & 104 & 26.4 \\
\hline 0.353 & 318 & 211 & 107 & 5.0 & 104 & 26.4 \\
\hline 0.354 & 319 & 211 & 107 & 5.0 & 103 & 26.5 \\
\hline 0.355 & 320 & 212 & 108 & 5.0 & 102 & 26.5 \\
\hline 0.356 & 321 & 212 & 109 & 5.0 & 102 & 26.6 \\
\hline 0.357 & 321 & 212 & 110 & 5.0 & 101 & 26.6 \\
\hline 0.358 & 322 & 212 & 111 & 5.0 & 101 & 26.6 \\
\hline 0.359 & 323 & 212 & 111 & 5.0 & 100 & 26.7 \\
\hline 0.360 & 324 & 212 & 112 & 5.0 & 100 & 26.7 \\
\hline 0.361 & 325 & 212 & 113 & 5.0 & 99 & 26.8 \\
\hline 0.362 & 326 & 212 & 114 & 5.0 & 99 & 26.8 \\
\hline 0.363 & 327 & 212 & 115 & 5.0 & 98 & 26.9 \\
\hline 0.364 & 328 & 212 & 115 & 5.0 & 98 & 26.9 \\
\hline 0.365 & 329 & 213 & 116 & 5.0 & 97 & 27.0 \\
\hline 0.366 & 330 & 213 & 117 & 5.0 & 97 & 27.0 \\
\hline 0.367 & 330 & 213 & 118 & 5.0 & 96 & 27.0 \\
\hline 0.368 & 331 & 213 & 119 & 5.0 & 96 & 27.1 \\
\hline 0.369 & 332 & 213 & 119 & 5.0 & 95 & 27.1 \\
\hline
\end{tabular}




\begin{tabular}{|c|c|c|c|c|c|c|}
\hline $\begin{array}{l}\text { Time from } \\
\text { Initiation } \\
\text { (sec) }\end{array}$ & $\begin{array}{c}\text { Forebody } \\
\text { Travel } \\
\text { Distance } \\
\text { (ft) }\end{array}$ & $\begin{array}{l}\text { TM Pack } \\
\text { Travel } \\
\text { Distance } \\
\text { (ft) }\end{array}$ & $\begin{array}{c}\text { Wire } \\
\text { Deployed } \\
\text { (ft) }\end{array}$ & $\begin{array}{c}\text { Main } \\
\text { Parachute } \\
\text { Diameter } \\
\text { (f) }\end{array}$ & $\begin{array}{l}\text { Velocity of } \\
\text { Wire w/r/t } \\
\text { Ground } \\
\text { (fps) }\end{array}$ & $\begin{array}{c}\text { Main } \\
\text { Parachute } \\
\text { Drag Area } \\
\left(\mathrm{ft}^{\wedge} 2\right)\end{array}$ \\
\hline 0.370 & 333 & 213 & 120 & 5.0 & 95 & 27.2 \\
\hline 0.371 & 334 & 213 & 121 & 5.0 & 94 & 27.2 \\
\hline 0.372 & 335 & 213 & 122 & 5.0 & 94 & 27.3 \\
\hline 0.373 & 336 & 213 & 123 & 5.0 & 93 & 27.3 \\
\hline 0.374 & 337 & 213 & 123 & 5.0 & 93 & 27.3 \\
\hline 0.375 & 338 & 214 & 124 & 5.1 & 92 & 27.4 \\
\hline 0.376 & 339 & 214 & 125 & 5.1 & 92 & 27.4 \\
\hline 0.377 & 339 & 214 & 126 & 5.1 & 92 & 27.5 \\
\hline 0.378 & 340 & 214 & 127 & 5.1 & 91 & 27.5 \\
\hline 0.379 & 341 & 214 & 127 & 5.1 & 91 & 27.6 \\
\hline 0.380 & 342 & 214 & 128 & 5.1 & 90 & 27.6 \\
\hline 0.381 & 343 & 214 & 129 & 5.1 & 90 & 27.6 \\
\hline 0.382 & 344 & 214 & 130 & 5.1 & 90 & 27.7 \\
\hline 0.383 & 345 & 214 & 131 & 5.1 & 89 & 27.7 \\
\hline 0.384 & 346 & 214 & 131 & 5.1 & 89 & 27.8 \\
\hline 0.385 & 347 & 214 & 132 & 5.1 & 88 & 27.8 \\
\hline 0.386 & 348 & 215 & 133 & 5.1 & 88 & 27.8 \\
\hline 0.387 & 348 & 215 & 134 & 5.1 & 88 & 27.9 \\
\hline 0.388 & 349 & 215 & 135 & 5.1 & 87 & 27.9 \\
\hline 0.389 & 350 & 215 & 136 & 5.1 & 87 & 28.0 \\
\hline 0.390 & 351 & 215 & 136 & 5.1 & 87 & 28.0 \\
\hline 0.391 & 352 & 215 & 137 & 5.1 & 86 & 28.0 \\
\hline 0.392 & 353 & 215 & 138 & 5.1 & 86 & 28.1 \\
\hline 0.393 & 354 & 215 & 139 & 5.1 & 85 & 28.1 \\
\hline 0.394 & 355 & 215 & 140 & 5.1 & 85 & 28.2 \\
\hline 0.395 & 356 & 215 & 140 & 5.1 & 85 & 28.2 \\
\hline 0.396 & 357 & 215 & 141 & 5.1 & 84 & 28.2 \\
\hline 0.397 & 357 & 215 & 142 & 5.1 & 84 & 28.3 \\
\hline 0.398 & 358 & 216 & 143 & 5.1 & 84 & 28.3 \\
\hline 0.399 & 359 & 216 & 144 & 5.1 & 83 & 28.3 \\
\hline 0.400 & 360 & 216 & 145 & 5.1 & 83 & 28.4 \\
\hline 0.401 & 361 & 216 & 145 & 5.1 & 83 & 28.4 \\
\hline 0.402 & 362 & 216 & 146 & 5.2 & 82 & 28.5 \\
\hline 0.403 & 363 & 216 & 147 & 5.2 & 82 & 28.5 \\
\hline 0.404 & 364 & 216 & 148 & 5.2 & 82 & 28.5 \\
\hline 0.405 & 365 & 216 & 149 & 5.2 & 82 & 28.6 \\
\hline 0.406 & 366 & 216 & 149 & 5.2 & 81 & 28.6 \\
\hline 0.407 & 366 & 216 & 150 & 5.2 & 81 & 28.6 \\
\hline 0.408 & 367 & 216 & 151 & 5.2 & 81 & 28.7 \\
\hline 0.409 & 368 & 216 & 152 & 5.2 & 80 & 28.7 \\
\hline 0.410 & 369 & 217 & 153 & 5.2 & 80 & 28.8 \\
\hline 0.411 & 370 & 217 & 154 & 5.2 & 80 & 28.8 \\
\hline 0.412 & 371 & 217 & 154 & 5.2 & 80 & 28.8 \\
\hline 0.413 & 372 & 217 & 155 & 5.2 & 79 & 28.9 \\
\hline 0.414 & 373 & 217 & 156 & 5.2 & 79 & 28.9 \\
\hline 0.415 & 374 & 217 & 157 & 5.2 & 79 & 28.9 \\
\hline 0.416 & 375 & 217 & 158 & 5.2 & 78 & 29.0 \\
\hline 0.417 & 376 & 217 & 158 & 5.2 & 78 & 29.0 \\
\hline 0.418 & 376 & 217 & 159 & 5.2 & 78 & 29.0 \\
\hline 0.419 & 377 & 217 & 160 & 5.2 & 78 & 29.1 \\
\hline 0.420 & 378 & 217 & 161 & 5.2 & 77 & 29.1 \\
\hline 0.421 & 379 & 217 & 162 & 5.2 & 77 & 29.1 \\
\hline 0.422 & 380 & 217 & 163 & 5.2 & 77 & 29.2 \\
\hline 0.423 & 381 & 218 & 163 & 5.2 & 77 & 29.2 \\
\hline 0.424 & 382 & 218 & 164 & 5.2 & 76 & 29.3 \\
\hline 0.425 & 383 & 218 & 165 & 5.2 & 76 & 29.3 \\
\hline 0.426 & 384 & 218 & 166 & 5.2 & 76 & 29.3 \\
\hline 0.427 & 385 & 218 & 167 & 5.2 & 76 & 29.4 \\
\hline 0.428 & 385 & 218 & 168 & 5.2 & 75 & 29.4 \\
\hline 0.429 & 386 & 218 & 168 & 5.2 & 75 & 29.4 \\
\hline 0.430 & 387 & 218 & 169 & 5.2 & 75 & 29.5 \\
\hline
\end{tabular}




\begin{tabular}{|c|c|c|c|c|c|c|}
\hline $\begin{array}{l}\text { Time from } \\
\text { Initiation } \\
\text { (sec) }\end{array}$ & $\begin{array}{c}\text { Forebody } \\
\text { Travel } \\
\text { Distance } \\
\text { (ft) }\end{array}$ & $\begin{array}{c}\text { TM Pack } \\
\text { Travel } \\
\text { Distance } \\
\text { (ft) }\end{array}$ & $\begin{array}{c}\text { Wire } \\
\text { Deployed } \\
\text { (ft) }\end{array}$ & $\begin{array}{c}\text { Main } \\
\text { Parachute } \\
\text { Diameter } \\
\text { (ft) }\end{array}$ & $\begin{array}{c}\text { Velocity of } \\
\text { Wire w/r/t } \\
\text { Ground } \\
\text { (fps) }\end{array}$ & $\begin{array}{c}\text { Main } \\
\text { Parachute } \\
\text { Drag Area } \\
\left(\mathrm{ft}^{\wedge} 2\right)\end{array}$ \\
\hline 0.431 & 388 & 218 & 170 & 5.2 & 75 & 29.5 \\
\hline 0.432 & 389 & 218 & 171 & 5.3 & 75 & 29.5 \\
\hline 0.433 & 390 & 218 & 172 & 5.3 & 74 & 29.6 \\
\hline 0.434 & 391 & 218 & 172 & 5.3 & 74 & 29.6 \\
\hline 0.435 & 392 & 218 & 173 & 5.3 & 74 & 29.6 \\
\hline 0.436 & 393 & 219 & 174 & 5.3 & 74 & 29.7 \\
\hline 0.437 & 394 & 219 & 175 & 5.3 & 73 & 29.7 \\
\hline 0.438 & 394 & 219 & 176 & 5.3 & 73 & 29.7 \\
\hline 0.439 & 395 & 219 & 177 & 5.3 & 73 & 29.8 \\
\hline 0.440 & 396 & 219 & 177 & 5.3 & 73 & 29.8 \\
\hline 0.441 & 397 & 219 & 178 & 5.3 & 73 & 29.8 \\
\hline 0.442 & 398 & 219 & 179 & 5.3 & 72 & 29.9 \\
\hline 0.443 & 399 & 219 & 180 & 5.3 & 72 & 29.9 \\
\hline 0.444 & 400 & 219 & 181 & 5.3 & 72 & 29.9 \\
\hline 0.445 & 401 & 219 & 182 & 5.3 & 72 & 30.0 \\
\hline 0.446 & 402 & 219 & 182 & 5.3 & 72 & 30.0 \\
\hline 0.447 & 403 & 219 & 183 & 5.3 & 71 & 30.0 \\
\hline 0.448 & 404 & 219 & 184 & 5.3 & 71 & 30.1 \\
\hline 0.449 & 404 & 219 & 185 & 5.3 & 71 & 30.1 \\
\hline 0.450 & 405 & 220 & 186 & 5.3 & 71 & 30.1 \\
\hline 0.451 & 406 & 220 & 187 & 5.3 & 71 & 30.2 \\
\hline 0.452 & 407 & 220 & 187 & 5.3 & 70 & 30.2 \\
\hline 0.453 & 408 & 220 & 188 & 5.3 & 70 & 30.2 \\
\hline 0.454 & 409 & 220 & 189 & 5.3 & 70 & 30.2 \\
\hline 0.455 & 410 & 220 & 190 & 5.3 & 70 & 30.3 \\
\hline 0.456 & 411 & 220 & 191 & 5.3 & 70 & 30.3 \\
\hline 0.457 & 412 & 220 & 192 & 5.3 & 70 & 30.3 \\
\hline 0.458 & 413 & 220 & 192 & 5.3 & 69 & 30.4 \\
\hline 0.459 & 413 & 220 & 193 & 5.3 & 69 & 30.4 \\
\hline 0.460 & 414 & 220 & 194 & 5.3 & 69 & 30.4 \\
\hline 0.461 & 415 & 220 & 195 & 5.3 & 69 & 30.5 \\
\hline 0.462 & 416 & 220 & 196 & 5.3 & 69 & 30.5 \\
\hline 0.463 & 417 & 220 & 197 & 5.3 & 69 & 30.5 \\
\hline 0.464 & 418 & 221 & 197 & 5.3 & 68 & 30.6 \\
\hline 0.465 & 419 & 221 & 198 & 5.3 & 68 & 30.6 \\
\hline 0.466 & 420 & 221 & 199 & 5.4 & 68 & 30.6 \\
\hline 0.467 & 421 & 221 & 200 & 5.4 & 68 & 30.7 \\
\hline 0.468 & 422 & 221 & 201 & 5.4 & 68 & 30.7 \\
\hline 0.469 & 422 & 221 & 202 & 5.4 & 68 & 30.7 \\
\hline 0.470 & 423 & 221 & 202 & 5.4 & 67 & 30.7 \\
\hline 0.471 & 424 & 221 & 203 & 5.4 & 67 & 30.8 \\
\hline 0.472 & 425 & 221 & 204 & 5.4 & 67 & 30.8 \\
\hline 0.473 & 426 & 221 & 205 & 5.4 & 67 & 30.8 \\
\hline 0.474 & 427 & 221 & 206 & 5.4 & 67 & 30.9 \\
\hline 0.475 & 428 & 221 & 207 & 5.4 & 67 & 30.9 \\
\hline 0.476 & 429 & 221 & 207 & 5.4 & 66 & 30.9 \\
\hline 0.477 & 430 & 221 & 208 & 5.4 & 66 & 31.0 \\
\hline 0.478 & 431 & 222 & 209 & 5.4 & 66 & 31.0 \\
\hline 0.479 & 432 & 222 & 210 & 5.4 & 66 & 31.0 \\
\hline 0.480 & 432 & 222 & 211 & 5.4 & 66 & 31.0 \\
\hline 0.481 & 433 & 222 & 212 & 5.4 & 66 & 31.1 \\
\hline 0.482 & 434 & 222 & 212 & 5.4 & 66 & 31.1 \\
\hline 0.483 & 435 & 222 & 213 & 5.4 & 66 & 31.1 \\
\hline 0.484 & 436 & 222 & 214 & 5.4 & 65 & 31.2 \\
\hline 0.485 & 437 & 222 & 215 & 5.4 & 65 & 31.2 \\
\hline 0.486 & 438 & 222 & 216 & 5.4 & 65 & 31.2 \\
\hline 0.487 & 439 & 222 & 217 & 5.4 & 65 & 31.3 \\
\hline 0.488 & 440 & 222 & 217 & 5.4 & 65 & 31.3 \\
\hline 0.489 & 441 & 222 & 218 & 5.4 & 65 & 31.3 \\
\hline 0.490 & 441 & 222 & 219 & 5.4 & 65 & 31.3 \\
\hline 0.491 & 442 & 222 & 220 & 5.4 & 65 & 31.4 \\
\hline 0.492 & 443 & 222 & 221 & 5.4 & 64 & 31.4 \\
\hline 0.493 & 444 & 223 & 222 & 5.4 & 64 & 31.4 \\
\hline 0.494 & 445 & 223 & 222 & 5.4 & 64 & 31.5 \\
\hline 0.495 & 446 & 223 & 223 & 5.4 & 64 & 31.5 \\
\hline
\end{tabular}




\begin{tabular}{|c|c|c|c|c|c|c|}
\hline $\begin{array}{c}\text { Time from } \\
\text { Initiation } \\
\text { (sec) }\end{array}$ & $\begin{array}{c}\text { Forebody } \\
\text { Travel } \\
\text { Distance } \\
\text { (ft) }\end{array}$ & $\begin{array}{l}\text { TM Pack } \\
\text { Travel } \\
\text { Distance } \\
\text { (ft) }\end{array}$ & $\begin{array}{c}\text { Wire } \\
\text { Deployed } \\
\text { (ft) }\end{array}$ & $\begin{array}{c}\text { Main } \\
\text { Parachute } \\
\text { Diameter } \\
\text { (ft) }\end{array}$ & $\begin{array}{l}\text { Velocity of } \\
\text { Wire w/r/t } \\
\text { Ground } \\
\text { (fps) }\end{array}$ & $\begin{array}{c}\text { Main } \\
\text { Parachute } \\
\text { Drag Area } \\
\left(\mathrm{f}^{\wedge} 2\right)\end{array}$ \\
\hline 0.496 & 447 & 223 & 224 & 5.4 & 64 & 31.5 \\
\hline 0.497 & 448 & 223 & 225 & 5.4 & 64 & 31.5 \\
\hline 0.498 & 449 & 223 & 226 & 5.4 & 64 & 31.6 \\
\hline 0.499 & 450 & 223 & 227 & 5.4 & 64 & 31.6 \\
\hline$\therefore 0.500$ & 450 & 223 & 227 & 5.4 & 63 & 31.6 \\
\hline 0.501 & 451 & 223 & 228 & 5.4 & 63 & 31.7 \\
\hline 0.502 & 452 & 223 & 229 & 5.4 & 63 & 31.7 \\
\hline 0.503 & 453 & 223 & 230 & 5.4 & 63 & 31.7 \\
\hline 0.504 & 454 & 223 & 231 & 5.5 & 63 & 31.8 \\
\hline 0.505 & 455 & 223 & 232 & 5.5 & 63 & 31.8 \\
\hline 0.506 & 456 & 223 & 232 & 5.5 & 63 & 31.8 \\
\hline 0.507 & 457 & 223 & 233 & 5.5 & 63 & 31.8 \\
\hline 0.508 & 458 & 223 & 234 & 5.5 & 63 & 31.9 \\
\hline 0.509 & 459 & 224 & 235 & 5.5 & 62 & 31.9 \\
\hline 0.510 & 459 & 224 & 236 & 5.5 & 62 & 31.9 \\
\hline 0.511 & 460 & 224 & 237 & 5.5 & 62 & 31.9 \\
\hline 0.512 & 461 & 224 & 238 & 5.5 & 62 & 32.0 \\
\hline 0.513 & 462 & 224 & 238 & 5.5 & 62 & 32.0 \\
\hline 0.514 & 463 & 224 & 239 & 5.5 & 62 & 32.0 \\
\hline 0.515 & 464 & 224 & 240 & 5.5 & 62 & 32.1 \\
\hline 0.516 & 465 & 224 & 241 & 5.5 & 62 & 32.1 \\
\hline 0.517 & 466 & 224 & 242 & 5.5 & 62 & 32.1 \\
\hline 0.518 & 467 & 224 & 243 & 5.5 & 62 & 32.1 \\
\hline 0.519 & 468 & 224 & 243 & 5.5 & 61 & 32.2 \\
\hline 0.520 & 468 & 224 & 244 & 5.5 & 61 & 32.2 \\
\hline 0.521 & 469 & 224 & 245 & 5.5 & 61 & 32.2 \\
\hline 0.522 & 470 & 224 & 246 & 5.5 & 61 & 32.3 \\
\hline 0.523 & 471 & 224 & 247 & 5.5 & 61 & 32.3 \\
\hline 0.524 & 472 & 224 & 248 & 5.5 & 61 & 32.3 \\
\hline 0.525 & 473 & 225 & 248 & 5.5 & 61 & 32.3 \\
\hline 0.526 & 474 & 225 & 249 & 5.5 & 61 & 32.4 \\
\hline 0.527 & 475 & 225 & 250 & 5.5 & 61 & 32.4 \\
\hline 0.528 & 476 & 225 & 251 & 5.5 & 61 & 32.4 \\
\hline 0.529 & 477 & 225 & 252 & 5.5 & 61 & 32.4 \\
\hline 0.530 & 477 & 225 & 253 & 5.5 & 60 & 32.5 \\
\hline 0.531 & 478 & 225 & 253 & 5.5 & 60 & 32.5 \\
\hline 0.532 & 479 & 225 & 254 & 5.5 & 60 & 32.5 \\
\hline 0.533 & 480 & 225 & 255 & 5.5 & 60 & 32.6 \\
\hline 0.534 & 481 & 225 & 256 & 5.5 & 60 & 32.6 \\
\hline 0.535 & 482 & 225 & 257 & 5.5 & 60 & 32.6 \\
\hline 0.536 & 483 & 225 & 258 & 5.5 & 60 & 32.6 \\
\hline 0.537 & 484 & 225 & 259 & 5.5 & 60 & 32.7 \\
\hline 0.538 & 485 & 225 & 259 & 5.5 & 60 & 32.7 \\
\hline 0.539 & 486 & 225 & 260 & 5.5 & 60 & 32.7 \\
\hline 0.540 & 486 & 225 & 261 & 5.5 & 60 & 32.7 \\
\hline 0.541 & 487 & 226 & 262 & 5.5 & 59 & 32.8 \\
\hline 0.542 & 488 & 226 & 263 & 5.5 & 59 & 32.8 \\
\hline 0.543 & 489 & 226 & 264 & 5.5 & 59 & 32.8 \\
\hline 0.544 & 490 & 226 & 264 & 5.5 & 59 & 32.9 \\
\hline 0.545 & 491 & 226 & 265 & 5.6 & 59 & 32.9 \\
\hline 0.546 & 492 & 226 & 266 & 5.6 & 59 & 32.9 \\
\hline 0.547 & 493 & 226 & 267 & 5.6 & 59 & 32.9 \\
\hline 0.548 & 494 & 226 & 268 & 5.6 & 59 & 33.0 \\
\hline 0.549 & 495 & 226 & 269 & 5.6 & 59 & 33.0 \\
\hline 0.550 & 496 & 226 & 269 & 5.6 & 59 & 33.0 \\
\hline 0.551 & 496 & 226 & 270 & 5.6 & 59 & 33.0 \\
\hline 0.552 & 497 & 226 & 271 & 5.6 & 59 & 33.1 \\
\hline 0.553 & 498 & 226 & 272 & 5.6 & 59 & 33.1 \\
\hline 0.554 & 499 & 226 & 273 & 5.6 & 58 & 33.1 \\
\hline 0.555 & 500 & 226 & 274 & 5.6 & 58 & 33.1 \\
\hline 0.556 & 501 & 226 & 275 & 5.6 & 58 & 33.2 \\
\hline 0.557 & 502 & 227 & 275 & 5.6 & 58 & 33.2 \\
\hline
\end{tabular}




\begin{tabular}{|c|c|c|c|c|c|c|}
\hline $\begin{array}{l}\text { Time from } \\
\text { Initiation } \\
\text { (sec) }\end{array}$ & $\begin{array}{c}\text { Forebody } \\
\text { Travel } \\
\text { Distance } \\
\text { (ft) }\end{array}$ & $\begin{array}{c}\text { TM Pack } \\
\text { Travel } \\
\text { Distance } \\
\text { (ft) }\end{array}$ & $\begin{array}{c}\text { Wire } \\
\text { Deployed } \\
(f t)\end{array}$ & $\begin{array}{c}\text { Main } \\
\text { Parachute } \\
\text { Diameter } \\
(f t)\end{array}$ & $\begin{array}{c}\text { Velocity of } \\
\text { Wire w/r/t } \\
\text { Ground } \\
\text { (fps) }\end{array}$ & $\begin{array}{c}\text { Main } \\
\text { Parachut } \\
\text { Drag Are } \\
\left(\mathrm{H}^{\wedge} 2\right)\end{array}$ \\
\hline 0.558 & 503 & 227 & 276 & 5.6 & 58 & 33.2 \\
\hline 0.559 & 504 & 227 & 277 & 5.6 & 58 & 33.3 \\
\hline 0.560 & 505 & 227 & 278 & 5.6 & 58 & 33.3 \\
\hline 0.561 & 505 & 227 & 279 & 5.6 & 58 & 33.3 \\
\hline 0.562 & 506 & 227 & 280 & 5.6 & 58 & 33.3 \\
\hline 0.563 & 507 & 227 & 280 & 5.6 & 58 & 33.4 \\
\hline 0.564 & 508 & 227 & 281 & 5.6 & 58 & 33.4 \\
\hline 0.565 & 509 & 227 & 282 & 5.6 & 58 & 33.4 \\
\hline 0.566 & 510 & 227 & 283 & 5.6 & 58 & 33.4 \\
\hline 0.567 & 511 & 227 & 284 & 5.6 & 58 & 33.5 \\
\hline 0.568 & 512 & 227 & 285 & 5.6 & 57 & 33.5 \\
\hline 0.569 & 513 & 227 & 286 & 5.6 & 57 & 33.5 \\
\hline 0.570 & 514 & 227 & 286 & 5.6 & 57 & 33.5 \\
\hline 0.571 & 515 & 227 & 287 & 5.6 & 57 & 33.6 \\
\hline 0.572 & 515 & 227 & 288 & 5.6 & 57 & 33.6 \\
\hline 0.573 & 516 & 227 & 289 & 5.6 & 57 & 33.6 \\
\hline 0.574 & 517 & 228 & 290 & 5.6 & 57 & 33.6 \\
\hline 0.575 & 518 & 227 & 291 & 5.6 & 57 & 33.7 \\
\hline 0.576 & 519 & 228 & 291 & 5.6 & 57 & 33.7 \\
\hline 0.577 & 520 & 228 & 292 & 5.6 & 57 & 33.7 \\
\hline 0.578 & 521 & 228 & 293 & 5.6 & 57 & 33.7 \\
\hline 0.579 & 522 & 228 & 294 & 5.6 & 57 & 33.8 \\
\hline 0.580 & 523 & 228 & 295 & 5.6 & 57 & 33.8 \\
\hline 0.581 & 524 & 228 & 296 & 5.6 & 57 & 33.8 \\
\hline 0.582 & 524 & 228 & 296 & 5.6 & 57 & 33.9 \\
\hline 0.583 & 525 & 228 & 297 & 5.6 & 57 & 33.9 \\
\hline 0.584 & 526 & 228 & 298 & 5.6 & 57 & 33.9 \\
\hline 0.585 & 527 & 228 & 299 & 5.6 & 56 & 33.9 \\
\hline 0.586 & 528 & 228 & 300 & 5.6 & 56 & 34.0 \\
\hline 0.587 & 529 & 228 & 301 & 5.6 & 56 & 34.0 \\
\hline 0.588 & 530 & 228 & 302 & 5.6 & 56 & 34.0 \\
\hline 0.589 & 531 & 228 & 302 & 5.6 & 56 & 34.0 \\
\hline 0.590 & 532 & 228 & 303 & 5.7 & 56 & 34.1 \\
\hline 0.591 & 533 & 228 & 304 & 5.7 & 56 & 34.1 \\
\hline 0.592 & 533 & 229 & 305 & 5.7 & 56 & 34.1 \\
\hline 0.593 & 534 & 229 & 306 & 5.7 & 56 & 34.1 \\
\hline 0.594 & 535 & 229 & 307 & 5.7 & 56 & 34.2 \\
\hline 0.595 & 536 & 229 & 307 & 5.7 & 56 & 34.2 \\
\hline 0.596 & 537 & 229 & 308 & 5.7 & 56 & 34.2 \\
\hline 0.597 & 538 & 229 & 309 & 5.7 & 56 & 34.2 \\
\hline 0.598 & 539 & 229 & 310 & 5.7 & 56 & 34.3 \\
\hline 0.599 & 540 & 229 & 311 & 5.7 & 56 & 34.3 \\
\hline 0.600 & 541 & 229 & 312 & 5.7 & 56 & 34.3 \\
\hline 0.601 & 542 & 229 & 313 & 5.7 & 56 & 34.3 \\
\hline 0.602 & 542 & 229 & 313 & 5.7 & 56 & 34.4 \\
\hline 0.603 & 543 & 229 & 314 & 5.7 & 56 & 34.4 \\
\hline 0.604 & 544 & 229 & 315 & 5.7 & 55 & 34.4 \\
\hline 0.605 & 545 & 229 & 316 & 5.7 & 55 & 34.4 \\
\hline 0.606 & 546 & 229 & 317 & 5.7 & 55 & 34.5 \\
\hline 0.607 & 547 & 229 & 318 & 5.7 & 55 & 34.5 \\
\hline 0.608 & 548 & 229 & 318 & 5.7 & 55 & 34.5 \\
\hline 0.609 & 549 & 229 & 319 & 5.7 & 55 & 34.5 \\
\hline 0.610 & 550 & 230 & 320 & 5.7 & 55 & 34.6 \\
\hline 0.611 & 551 & 230 & 321 & 5.7 & 55 & 34.6 \\
\hline 0.612 & 551 & 230 & 322 & 5.7 & 55 & 34.6 \\
\hline 0.613 & 552 & 230 & 323 & 5.7 & 55 & 34.6 \\
\hline 0.614 & 553 & 230 & 324 & 5.7 & 55 & 34.7 \\
\hline 0.615 & 554 & 230 & 324 & 5.7 & 55 & 34.7 \\
\hline 0.616 & 555 & 230 & 325 & 5.7 & 55 & 34.7 \\
\hline 0.617 & 556 & 230 & 326 & 5.7 & 55 & 34.7 \\
\hline 0.618 & 557 & 230 & 327 & 5.7 & 55 & 34.8 \\
\hline 0.619 & 558 & 230 & 328 & $5.7^{\circ}$ & 55 & 34.8 \\
\hline
\end{tabular}




\begin{tabular}{|c|c|c|c|c|c|c|}
\hline $\begin{array}{c}\text { Time from } \\
\text { Initiation } \\
\text { (sec) }\end{array}$ & $\begin{array}{c}\text { Forebody } \\
\text { Travel } \\
\text { Distance } \\
\text { (ft) }\end{array}$ & $\begin{array}{c}\text { TM Pack } \\
\text { Travel } \\
\text { Distance } \\
\text { (ft) }\end{array}$ & $\begin{array}{c}\text { Wire } \\
\text { Deployed } \\
\text { (ft) }\end{array}$ & $\begin{array}{c}\text { Main } \\
\text { Parachute } \\
\text { Diameter } \\
\text { (ft) }\end{array}$ & $\begin{array}{c}\text { Velocity of } \\
\text { Wire w/r/t } \\
\text { Ground } \\
\text { (fps) }\end{array}$ & $\begin{array}{c}\text { Main } \\
\text { Parachute } \\
\text { Drag Area } \\
\left(\mathrm{ft}^{\wedge} 2\right)\end{array}$ \\
\hline 0.620 & 559 & 230 & 329 & 5.7 & 55 & 34.8 \\
\hline 0.621 & 560 & 230 & 329 & 5.7 & 55 & 34.8 \\
\hline 0.622 & 560 & 230 & 330 & 5.7 & 55 & 34.9 \\
\hline 0.623 & 561 & 230 & 331 & 5.7 & 54 & 34.9 \\
\hline 0.624 & 562 & 230 & 332 & 5.7 & 54 & 34.9 \\
\hline 0.625 & 563 & 230 & 333 & 5.7 & 54 & 34.9 \\
\hline 0.626 & 564 & 230 & 334 & 5.7 & 54 & 35.0 \\
\hline 0.627 & 565 & 231 & 335 & 5.7 & 54 & 35.0 \\
\hline 0.628 & 566 & 231 & 335 & 5.7 & 54 & 35.0 \\
\hline 0.629 & 567 & 231 & 336 & 5.7 & 54 & 35.0 \\
\hline 0.630 & 568 & 231 & 337 & 5.7 & 54 & 35.1 \\
\hline 0.631 & 569 & 231 & 338 & 5.7 & 54 & 35.1 \\
\hline 0.632 & 570 & 231 & 339 & 5.7 & 54 & 35.1 \\
\hline 0.633 & 570 & 231 & 340 & 5.7 & 54 & 35.1 \\
\hline 0.634 & 571 & 231 & 340 & 5.7 & 54 & 35.2 \\
\hline 0.635 & 572 & 231 & 341 & 5.7 & 54 & 35.2 \\
\hline 0.636 & 573 & 231 & 342 & 5.7 & 54 & 35.2 \\
\hline 0.637 & 574 & 231 & 343 & 5.8 & 54 & 35.2 \\
\hline 0.638 & 575 & 231 & 344 & 5.8 & 54 & 35.3 \\
\hline 0.639 & 576 & 231 & 345 & 5.8 & 54 & 35.3 \\
\hline 0.640 & 577 & 231 & 346 & 5.8 & 54 & 35.3 \\
\hline 0.641 & 578 & 231 & 346 & 5.8 & 54 & 35.3 \\
\hline 0.642 & 579 & 231 & 347 & 5.8 & 54 & 35.3 \\
\hline 0.643 & 580 & 231 & 348 & 5.8 & 54 & 35.4 \\
\hline 0.644 & 580 & 231 & 349 & 5.8 & 54 & 35.4 \\
\hline 0.645 & 581 & 231 & 350 & 5.8 & 54 & 35.4 \\
\hline 0.646 & 582 & 232 & 351 & 5.8 & 54 & 35.4 \\
\hline 0.647 & 583 & 232 & 352 & 5.8 & 53 & 35.5 \\
\hline 0.648 & 584 & 232 & 352 & 5.8 & 53 & 35.5 \\
\hline 0.649 & 585 & 232 & 353 & 5.8 & 53 & 35.5 \\
\hline 0.650 & 586 & 232 & 354 & 5.8 & 53 & 35.5 \\
\hline 0.651 & 587 & 232 & 355 & 5.8 & 53 & 35.6 \\
\hline 0.652 & 588 & 232 & 356 & 5.8 & 53 & 35.6 \\
\hline 0.653 & 589 & 232 & 357 & 5.8 & 53 & 35.6 \\
\hline 0.654 & 589 & 232 & 357 & 5.8 & 53 & 35.6 \\
\hline 0.655 & 590 & 232 & 358 & 5.8 & 53 & 35.7 \\
\hline 0.656 & 591 & 232 & 359 & 5.8 & 53 & 35.7 \\
\hline 0.657 & 592 & 232 & 360 & 5.8 & 53 & 35.7 \\
\hline 0.658 & 593 & 232 & 361 & 5.8 & 53 & 35.7 \\
\hline 0.659 & 594 & 232 & 362 & 5.8 & 53 & 35.8 \\
\hline 0.660 & 595 & 232 & 363 & 5.8 & 53 & 35.8 \\
\hline 0.661 & 596 & 232 & 363 & 5.8 & 53 & 35.8 \\
\hline 0.662 & 597 & 232 & 364 & 5.8 & 53 & 35.8 \\
\hline 0.663 & 598 & 232 & 365 & 5.8 & 53 & 35.9 \\
\hline 0.664 & 598 & 233 & 366 & 5.8 & 53 & 35.9 \\
\hline 0.665 & 599 & 233 & 367 & 5.8 & 53 & 35.9 \\
\hline 0.666 & 600 & 233 & 368 & 5.8 & 53 & 35.9 \\
\hline 0.667 & 601 & 233 & 368 & 5.8 & 53 & 36.0 \\
\hline 0.668 & 602 & 233 & 369 & 5.8 & 53 & 36.0 \\
\hline 0.669 & 603 & 233 & 370 & 5.8 & 53 & 36.0 \\
\hline 0.670 & 604 & 233 & 371 & 5.8 & 53 & 36.0 \\
\hline 0.671 & 605 & 233 & 372 & 5.8 & 53 & 36.0 \\
\hline 0.672 & 606 & 233 & 373 & 5.8 & 53 & 36.1 \\
\hline 0.673 & 607 & 233 & 374 & 5.8 & 53 & 36.1 \\
\hline 0.674 & 608 & 233 & 374 & 5.8 & 53 & 36.1 \\
\hline 0.675 & 608 & 233 & 375 & 5.8 & 52 & 36.1 \\
\hline 0.676 & 609 & 233 & 376 & 5.8 & 53 & 36.2 \\
\hline 0.677 & 610 & 233 & 377 & 5.8 & 53 & 36.2 \\
\hline 0.678 & 611 & 233 & 378 & 5.8 & 52 & 36.2 \\
\hline 0.679 & 612 & 233 & 379 & 5.8 & 52 & 36.2 \\
\hline 0.680 & 613 & 233 & 380 & 5.8 & 52 & 36.3 \\
\hline
\end{tabular}




\begin{tabular}{|c|c|c|c|c|c|c|}
\hline $\begin{array}{l}\text { Time from } \\
\text { Initiation } \\
\text { (sec) }\end{array}$ & $\begin{array}{c}\text { Forebody } \\
\text { Travel } \\
\text { Distance } \\
\text { (ft) }\end{array}$ & $\begin{array}{c}\text { TM Pack } \\
\text { Travel } \\
\text { Distance } \\
\text { (ft) }\end{array}$ & $\begin{array}{c}\text { Wire } \\
\text { Deployed } \\
\text { (ft) }\end{array}$ & $\begin{array}{c}\text { Main } \\
\text { Parachute } \\
\text { Diameter } \\
(f t)\end{array}$ & $\begin{array}{l}\text { Velocity of } \\
\text { Wire w/r/h } \\
\text { Ground } \\
\text { (fps) }\end{array}$ & $\begin{array}{c}\text { Main } \\
\text { Parachute } \\
\text { Drag Area } \\
\left(\mathrm{t}^{\wedge} 2\right)\end{array}$ \\
\hline 0.681 & 614 & 233 & 380 & 5.8 & 52 & 36.3 \\
\hline 0.682 & 615 & 234 & 381 & 5.8 & 52 & 36.3 \\
\hline 0.683 & 616 & 234 & 382 & 5.8 & 52 & 36.3 \\
\hline 0.684 & 617 & 234 & 383 & 5.8 & 52 & 36.4 \\
\hline 0.685 & 617 & 234 & 384 & 5.8 & 52 & 36.4 \\
\hline 0.686 & 618 & 234 & 385 & 5.8 & 52 & 36.4 \\
\hline 0.687 & 619 & 234 & 385 & 5.8 & 52 & 36.4 \\
\hline 0.688 & 620 & 234 & 386 & 5.9 & 52 & 36.4 \\
\hline 0.689 & 621 & 234 & 387 & 5.9 & 52 & 36.5 \\
\hline 0.690 & 622 & 234 & 388 & 5.9 & 52 & 36.5 \\
\hline 0.691 & 623 & 234 & 389 & 5.9 & 52 & 36.5 \\
\hline 0.692 & 624 & 234 & 390 & 5.9 & 52 & 36.5 \\
\hline 0.693 & 625 & 234 & 391 & 5.9 & 52 & 36.6 \\
\hline 0.694 & 626 & 234 & 391 & 5.9 & 52 & 36.6 \\
\hline 0.695 & 626 & 234 & 392 & 5.9 & 52 & 36.6 \\
\hline 0.696 & 627 & 234 & 393 & 5.9 & 52 & 36.6 \\
\hline 0.697 & 628 & 234 & 394 & 5.9 & 52 & 36.7 \\
\hline 0.698 & 629 & 234 & 395 & 5.9 & 52 & 36.7 \\
\hline 0.699 & 630 & 234 & 396 & 5.9 & 52 & 36.7 \\
\hline 0.700 & 631 & 234 & 397 & 5.9 & 52 & 36.7 \\
\hline 0.701 & 632 & 235 & 397 & 5.9 & 52 & 36.8 \\
\hline 0.702 & 633 & 235 & 398 & 5.9 & 52 & 36.8 \\
\hline 0.703 & 634 & 235 & 399 & 5.9 & 52 & 36.8 \\
\hline 0.704 & 635 & 235 & 400 & 5.9 & 52 & 36.8 \\
\hline 0.705 & 636 & 235 & 401 & 5.9 & 52 & 36.8 \\
\hline 0.706 & 636 & 235 & 402 & 5.9 & 52 & 36.9 \\
\hline 0.707 & 637 & 235 & 402 & 5.9 & 52 & 36.9 \\
\hline 0.708 & 638 & 235 & 403 & 5.9 & 52 & 36.9 \\
\hline 0.709 & 639 & 235 & 404 & 5.9 & 52 & 36.9 \\
\hline 0.710 & 640 & 235 & 405 & 5.9 & 52 & 37.0 \\
\hline 0.711 & 641 & 235 & 406 & 5.9 & 51 & 37.0 \\
\hline 0.712 & 642 & 235 & 407 & 5.9 & 51 & 37.0 \\
\hline 0.713 & 643 & 235 & 408 & 5.9 & 51 & 37.0 \\
\hline 0.714 & 644 & 235 & 408 & 5.9 & 51 & 37.1 \\
\hline 0.715 & 645 & 235 & 409 & 5.9 & 51 & 37.1 \\
\hline 0.716 & 645 & 235 & 410 & 5.9 & 51 & 37.1 \\
\hline 0.717 & 646 & 235 & 411 & 5.9 & 51 & 37.1 \\
\hline 0.718 & 647 & 235 & 412 & 5.9 & 51 & 37.2 \\
\hline 0.719 & 648 & 236 & 413 & 5.9 & 51 & 37.2 \\
\hline 0.720 & 649 & 235 & 414 & 5.9 & 51 & 37.2 \\
\hline 0.721 & 650 & 236 & 414 & 5.9 & 51 & 37.2 \\
\hline 0.722 & 651 & 236 & 415 & 5.9 & 51 & 37.2 \\
\hline 0.723 & 652 & 236 & 416 & 5.9 & 51 & 37.3 \\
\hline 0.724 & 653 & 236 & 417 & 5.9 & 51 & 37.3 \\
\hline 0.725 & 654 & 236 & 418 & 5.9 & 51 & 37.3 \\
\hline 0.726 & 655 & 236 & 419 & 5.9 & 51 & 37.3 \\
\hline 0.727 & 655 & 236 & 419 & 5.9 & 51 & 37.4 \\
\hline 0.728 & 656 & 236 & 420 & 5.9 & 51 & 37.4 \\
\hline 0.729 & 657 & 236 & 421 & 5.9 & 51 & 37.4 \\
\hline 0.730 & 658 & 236 & 422 & 5.9 & 51 & 37.4 \\
\hline 0.731 & 659 & 236 & 423 & 5.9 & 51 & 37.5 \\
\hline 0.732 & 660 & 236 & 424 & 5.9 & 51 & 37.5 \\
\hline 0.733 & 661 & 236 & 425 & 5.9 & 51 & 37.5 \\
\hline 0.734 & 662 & 236 & 425 & 5.9 & 51 & 37.5 \\
\hline 0.735 & 663 & 236 & 426 & 5.9 & 51 & 37.5 \\
\hline 0.736 & 664 & 236 & 427 & 5.9 & 51 & 37.6 \\
\hline 0.737 & 664 & 236 & 428 & 5.9 & 51 & 37.6 \\
\hline 0.738 & 665 & 237 & 429 & 5.9 & 51 & 37.6 \\
\hline 0.739 & 666 & 236 & 430 & 5.9 & 51 & 37.6 \\
\hline 0.740 & 667 & 237 & 431 & 6.0 & 51 & 37.7 \\
\hline 0.741 & 668 & 237 & 431 & 6.0 & 51 & 37.7 \\
\hline 0.742 & 669 & 237 & 432 & 6.0 & 51 & 37.7 \\
\hline 0.743 & 670 & 237 & 433 & 6.0 & 51 & 37.7 \\
\hline 0.744 & 671 & 237 & 434 & 6.0 & 51 & 37.8 \\
\hline 0.745 & 672 & 237 & 435 & 6.0 & 51 & 37.8 \\
\hline
\end{tabular}




\begin{tabular}{|c|c|c|c|c|c|c|}
\hline $\begin{array}{c}\text { Time from } \\
\text { Initiation } \\
\text { (sec) }\end{array}$ & $\begin{array}{c}\text { Forebody } \\
\text { Travel } \\
\text { Distance } \\
\text { (ft) }\end{array}$ & $\begin{array}{l}\text { TM Pack } \\
\text { Travel } \\
\text { Distance } \\
\text { (ft) }\end{array}$ & $\begin{array}{c}\text { Wire } \\
\text { Deployed } \\
\text { (ft) }\end{array}$ & $\begin{array}{c}\text { Main } \\
\text { Parachute } \\
\text { Diameter } \\
\text { (t) }\end{array}$ & $\begin{array}{c}\text { Velocity of } \\
\text { Wire w/r/t } \\
\text { Ground } \\
\text { (fps) }\end{array}$ & $\begin{array}{c}\text { Main } \\
\text { Parachute } \\
\text { Drag Area } \\
\left(\mathrm{ft}^{\wedge} 2\right)\end{array}$ \\
\hline 0.746 & 673 & 237 & 436 & 6.0 & 51 & 37.8 \\
\hline 0.747 & 673 & 237 & 437 & 6.0 & 51 & 37.8 \\
\hline 0.748 & 674 & 237 & 437 & 6.0 & 51 & 37.8 \\
\hline 0.749 & 675 & 237 & 438 & 6.0 & 51 & 37.9 \\
\hline 0.750 & 676 & 237 & 439 & 6.0 & 50 & 37.9 \\
\hline 0.751 & 677 & 237 & 440 & 6.0 & 51 & 37.9 \\
\hline 0.752 & 678 & 237 & 441 & 6.0 & 51 & 37.9 \\
\hline 0.753 & 679 & 237 & 442 & 6.0 & 51 & 38.0 \\
\hline 0.754 & 680 & 237 & 442 & 6.0 & 50 & 38.0 \\
\hline 0.755 & 681 & 237 & 443 & 6.0 & 50 & 38.0 \\
\hline 0.756 & 682 & 237 & 444 & 6.0 & 50 & 38.0 \\
\hline 0.757 & 682 & 237 & 445 & 6.0 & 50 & 38.0 \\
\hline 0.758 & 683 & 238 & 446 & 6.0 & 50 & 38.1 \\
\hline 0.759 & 684 & 238 & 447 & 6.0 & 50 & 38.1 \\
\hline 0.760 & 685 & 238 & 448 & 6.0 & 50 & 38.1 \\
\hline 0.761 & 686 & 238 & 448 & 6.0 & 50 & 38.1 \\
\hline 0.762 & 687 & 238 & 449 & 6.0 & 50 & 38.2 \\
\hline 0.763 & 688 & 238 & 450 & 6.0 & 50 & 38.2 \\
\hline 0.764 & 689 & 238 & 451 & 6.0 & 50 & 38.2 \\
\hline 0.765 & 690 & 238 & 452 & 6.0 & 50 & 38.2 \\
\hline 0.766 & 691 & 238 & 453 & 6.0 & 50 & 38.3 \\
\hline 0.767 & 692 & 238 & 454 & 6.0 & 50 & 38.3 \\
\hline 0.768 & 692 & 238 & 454 & 6.0 & 50 & 38.3 \\
\hline 0.769 & 693 & 238 & 455 & 6.0 & 50 & 38.3 \\
\hline 0.770 & 694 & 238 & 456 & 6.0 & 50 & 38.3 \\
\hline 0.771 & 695 & 238 & 457 & 6.0 & 50 & 38.4 \\
\hline 0.772 & 696 & 238 & 458 & 6.0 & 50 & 38.4 \\
\hline 0.773 & 697 & 238 & 459 & 6.0 & 50 & 38.4 \\
\hline 0.774 & 698 & 238 & 460 & 6.0 & 50 & 38.4 \\
\hline 0.775 & 699 & 238 & 460 & 6.0 & 50 & 38.5 \\
\hline 0.776 & 700 & 238 & 461 & 6.0 & 50 & 38.5 \\
\hline 0.777 & 701 & 238 & 462 & 6.0 & 50 & 38.5 \\
\hline 0.778 & 702 & 239 & 463 & 6.0 & 50 & 38.5 \\
\hline 0.779 & 702 & 239 & 464 & 6.0 & 50 & 38.5 \\
\hline 0.780 & 703 & 239 & 465 & 6.0 & 50 & 38.6 \\
\hline 0.781 & 704 & 239 & 465 & 6.0 & 50 & 38.6 \\
\hline 0.782 & 705 & 239 & 466 & 6.0 & 50 & 38.6 \\
\hline 0.783 & 706 & 239 & 467 & 6.0 & 50 & 38.6 \\
\hline 0.784 & 707 & 239 & 468 & 6.0 & 50 & 38.7 \\
\hline 0.785 & 708 & 239 & 469 & 6.0 & 50 & 38.7 \\
\hline 0.786 & 709 & 239 & 470 & 6.0 & 50 & 38.7 \\
\hline 0.787 & 710 & 239 & 471 & 6.0 & 50 & 38.7 \\
\hline 0.788 & 711 & 239 & 471 & 6.0 & 50 & 38.8 \\
\hline 0.789 & 711 & 239 & 472 & 6.0 & 50 & 38.8 \\
\hline 0.790 & 712 & 239 & 473 & 6.0 & 50 & 38.8 \\
\hline 0.791 & 713 & 239 & 474 & 6.0 & 50 & 38.8 \\
\hline 0.792 & 714 & 239 & 475 & 6.0 & 50 & 38.8 \\
\hline 0.793 & 715 & 239 & 476 & 6.0 & 50 & 38.9 \\
\hline 0.794 & 716 & 239 & 477 & 6.0 & 50 & 38.9 \\
\hline 0.795 & 717 & 239 & 477 & 6.1 & 50 & 38.9 \\
\hline 0.796 & 718 & 239 & 478 & 6.1 & 50 & 38.9 \\
\hline 0.797 & 719 & 240 & 479 & 6.1 & 50 & 39.0 \\
\hline 0.798 & 720 & 240 & 480 & 6.1 & 50 & 39.0 \\
\hline 0.799 & 720 & 240 & 481 & 6.1 & 49 & 39.0 \\
\hline 0.800 & 721 & 240 & 482 & 6.1 & 49 & 39.0 \\
\hline 0.801 & 722 & 240 & 483 & 6.1 & 50 & 39.0 \\
\hline 0.802 & 723 & 240 & 483 & 6.1 & 50 & 39.1 \\
\hline 0.803 & 724 & 240 & 484 & 6.1 & 50 & 39.1 \\
\hline 0.804 & 725 & 240 & 485 & 6.1 & 49 & 39.1 \\
\hline 0.805 & 726 & 240 & 486 & 6.1 & 49 & 39.1 \\
\hline 0.806 & 727 & 240 & 487 & 6.1 & 49 & 39.2 \\
\hline 0.807 & 728 & 240 & 488 & 6.1 & 49 & 39.2 \\
\hline
\end{tabular}




\begin{tabular}{|c|c|c|c|c|c|c|}
\hline $\begin{array}{l}\text { Time from } \\
\text { Initiation } \\
\text { (sec) }\end{array}$ & $\begin{array}{l}\text { Forebody } \\
\text { Travel } \\
\text { Distance } \\
(\mathrm{ft})\end{array}$ & $\begin{array}{c}\text { TM Pack } \\
\text { Travel } \\
\text { Distance } \\
\text { (ft) }\end{array}$ & $\begin{array}{c}\text { Wire } \\
\text { Deployed } \\
\text { (ft) }\end{array}$ & $\begin{array}{c}\text { Main } \\
\text { Parachute } \\
\text { Diameter } \\
\text { (ft) }\end{array}$ & $\begin{array}{c}\text { Velocity of } \\
\text { Wire w/r/t } \\
\text { Ground } \\
\text { (fps) }\end{array}$ & $\begin{array}{c}\text { Main } \\
\text { Parachute } \\
\text { Drag Area } \\
\left(\mathrm{ft}^{\wedge} 2\right)\end{array}$ \\
\hline 0.808 & 729 & 240 & 489 & 6.1 & 49 & 39.2 \\
\hline 0.809 & 730 & 240 & 489 & 6.1 & 49 & 39.2 \\
\hline 0.810 & 730 & 240 & 490 & 6.1 & 49 & 39.2 \\
\hline 0.811 & 731 & 240 & 491 & 6.1 & 49 & 39.3 \\
\hline 0.812 & 732 & 240 & 492 & 6.1 & 49 & 39.3 \\
\hline 0.813 & 733 & 240 & 493 & 6.1 & 49 & 39.3 \\
\hline 0.814 & 734 & 240 & 494 & 6.1 & 49 & 39.3 \\
\hline 0.815 & 735 & 240 & 494 & 6.1 & 49 & 39.4 \\
\hline 0.816 & 736 & 241 & 495 & 6.1 & 49 & 39.4 \\
\hline 0.817 & 737 & 241 & 496 & 6.1 & 49 & 39.4 \\
\hline 0.818 & 738 & 241 & 497 & 6.1 & 49 & 39.4 \\
\hline 0.819 & 739 & 241 & 498 & 6.1 & 49 & 39.4 \\
\hline 0.820 & 739 & 241 & 499 & 6.1 & 49 & 39.5 \\
\hline 0.821 & 740 & 241 & 500 & 6.1 & 49 & 39.5 \\
\hline 0.822 & 741 & 241 & 500 & 6.1 & 49 & 39.5 \\
\hline
\end{tabular}




\section{DISTRIBUTION}

3 Air Force Research Laboratory

Attn: Mr. Harris C. Barker MNMF

306 West Eglin Blvd. 432

Eglin AFB, FL 32542-0543

$\begin{array}{rlll}1 & \text { MS0841 } & 9100 & \text { P. J. Hommert } \\ 1 & \text { MS0820 } & 9101 & \text { T. C. Bickel } \\ 1 & \text { MS0836 } & 9116 & \text { C. W. Peterson } \\ 10 & \text { MS0836 } & 9116 & \text { V.L. Behr } \\ 1 & \text { MS9018 } & 8940-2 & \text { Central Technical Files } \\ 2 & \text { MS0899 } & 4916 & \text { Technical Library } \\ 2 & \text { MS0619 } & 12690 & \begin{array}{l}\text { Review \& Approval Desk } \\ \text { For DOE/OSTI }\end{array}\end{array}$




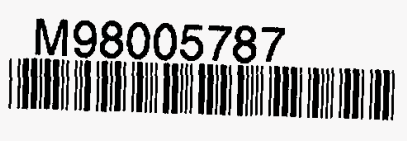

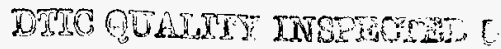

Report Number (14) SAND $-98-1059$
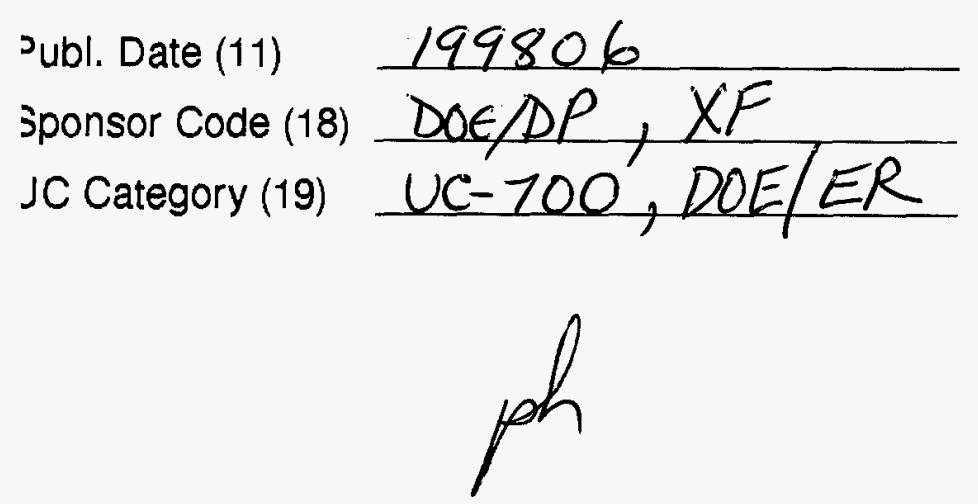

19980720029

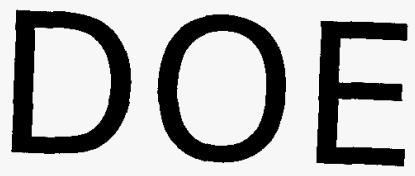

